\title{
CLONAGEM, CARACTERIZAÇÃO DA EXPRESSÃO GÊNICA E DO TRANSPORTE INTRA-ORGANELAR DA PROTEASE FtsH-p1 DE TOMATE (Lycopersicon esculentum Mill. cv. MicroTom)
}

\section{REINALDO MONTRAZI BARATA}

\author{
Tese apresentada à Escola Superior de \\ Agricultura "Luiz de Queiroz", Uhiversidade de \\ São Paulo, para obtenção do título de Doutor \\ em Agronomia, Área de Concentração: \\ Genética e Melhoramento de Plantas.
}

PIRACICABA

Estado de São Paulo - Brasil

Julho- 2003 


\section{CLONAGEM, CARACTERIZAÇÃO DA EXPRESSÃO GÊNICA E DO TRANSPORTE INTRA-ORGANELAR DA PROTEASE FtsH-p1 DE TOMATE (Lycopersicon esculentum Mill. cv. MicroTom)}

\section{REINALDO MONTRAZI BARATA}

Engenheiro Agrônomo

Orientador: Prof. Dr. MARCIO DE CASTRO SILVA FILHO

\footnotetext{
Tese apresentada à Escola Superior de Agricultura "Luiz de Queiroz", Universidade de São Paulo, para obtenção do título de Doutor em Agronomia, Área de Concentração: Genética e Melhoramento de Plantas.
}

PIRACICABA

Estado de São Paulo - Brasil

Julho- 2003 
Dados Internacionais de Catalogação na Publicação (CIP) DIVISÃO DE BIBLIOTECA E DOCUMENTAÇÃO - ESALQ/ USP

Barata, Reinaldo Montrazi

Clonagem, caracterização da expressão gênica e do transporte intraorganelar da protease FtsH-pl de tomate (Lycopersicon esculentum Mill. cV. Micro Tom) / Reinaldo Montrazi Barata. - - Piracicaba, 2003.

123 p. : il.

Tese (doutorado) - Escola Superior de Agricultura Luiz de Queiroz, 2003.

Bibliografia.

1. Citogenética vegetal 2. Clonagem 3. Enzimas 4. Expressão gênica 5. Melho-ramento genético vegetal 6 . Proteinas 7. Recombinação genética 8. Tomate I. Título

CDD 635.642 
Aos meus pais Renato e Suely,

\section{OFEREÇO}

A Sabrina e Nathália, responsáveis pelo estímulo e inspiração no dia-dia,

\section{DEDICO}




\section{AGRADECIMENTOS}

Agradeço a todas as pessoas que, de forma direta ou indireta, contribuíram para a realização deste trabalho, especialmente:

Ao Prof. Dr. Marcio de Castro Silva Filho pela orientação, amizade e paciência em todos os momentos;

A Fundação de Amparo à Pesquisa do Estado de São Paulo (FAPESP), pelo apoio financeiro;

A todos os professores, alunos e funcionários do Departamento de Genética da ESALQUSP, em especial aos técnicos Rafael Colombi e Carlos Alberto pelo auxílio e amizade;

Ao Prof. Dr. Lázaro Peres do Depto de Ciências Biológicas da ESALQUSP pelo fornecimento das sementes de tomate utilizadas nesse trabalho;

Aos colegas do Laboratório de Biologia Molecular de Plantas, ESALQ-USP, pela amizade, convivência e incentivo em todos os momentos;

Aos amigos Phellippe Marbach, Juliana Dantas e Juliana Aparecida Fernando, pela participação e obtenção dos resultados; 
Aos colegas do Laboratório de Biologia Celular, ESALQ - USP, pela amizade, e à Profa. Dra. Maria Lúcia Carneiro Vieira por colocar seu laboratório àdisposição.

Aos colegas do Laboratório de Citogenética, ESALQ - USP, e à Prof $^{a}$ Dra Margarida L. R. de Aguiar Perecin por colocar seu laboratório à disposição.

Aos colegas do Laboratório de Entomologia, Fitopatologia e Zoologia Agrícola, ESALQ - USP, em especial a Daniela Truffi e ao Prof. Dr. Luiz Eduardo Aranha Camargo pelas facilidades de seqüenciamento.

Aos funcionários do Setor de Biblioteca Central e do Departamento de Genética da ESALQ - USP, pelos auxílios prestados.

De maneira muito especial, a

Sabrina Moutinho Chabregas pela sua admirável paciência, amor e incentivo nas circunstâncias mais difíceis. 


\section{SUMÁRIO}

LISTA DE ABREVIATURAS ...............................................................

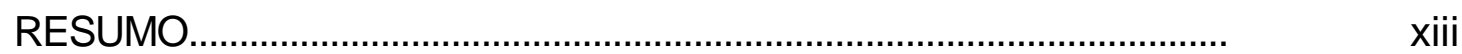

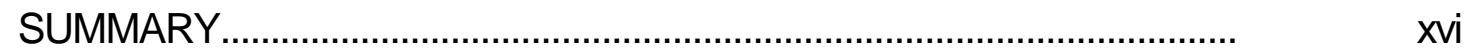

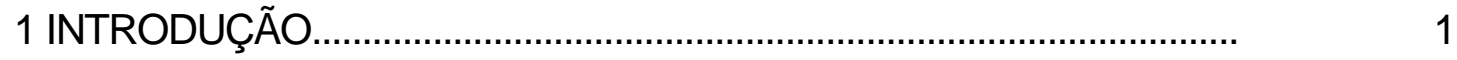

2 REVISÃO DE LITERATURA............................................................ 3

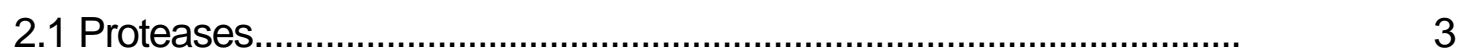

2.1.1 Proteases AAA ...................................................................... 4

2.1.2 FtsH - uma metaloprotease bacteriana...........................................

2.1.3 FtsHs em leveduras..................................................................

2.1.4 Proteínas AAA em plantas superiores................................................. 8

2.2 Importação de proteínas nos plastídios.................................................... 16

2.2.1 Via de inserção dependente de SRP (Signal Recognition Particle)..... 23

2.2.2 Direcionamento via Sec e dependente de Tat (Twin Arginine Translocation) ................................................................................. 25

2.2.2.1 Via de translocação Sec............................................................. 26

2.2.2.2 Via Tat dependente........................................................................ 28

2.2.3 Inserção espontânea de proteínas nas membranas dos tilacóides...... $\quad 29$

2.3 Regulação da expressão gênica........................................................ 31

3 MATERIAL E MÉTODOS..................................................................... 35

3.1 Clonagem do cDNA da FtsH-p1 de tomate e localização subcelular...... 35

3.1.1 Construções gênicas.................................................................. 35

3.1.2 Espécie Vegetal........................................................................... 35

3.1.3 Análise das seqüências homólogas àFtsH-p1 em plantas superiores depositadas em Banco de Dados..................................................... 35

3.1.4 Amplificação do fragmento correspondente àregião central do gene 
homólogo àFtsH-p1 de tomate.

3.1.4.1 Preparação do material e soluções para o isolamento de RNA total. 36

3.1.4.2 Extração de RNA de frutos e folhas de tomate.................................. 36

3.1.4.2.1 Homogenização.................................................................... 36

3.1.4.2.2 Fase de preparação.................................................................. 37

3.1.4.2.3 Precipitação do RNA...............................................................

3.1.4.2.4 Lavagem do RNA .................................................................. $\quad 37$

3.1.4.2.5 Ressuspensão do RNA............................................................. 38

3.1.5 Eletroforese de RNA em gel desnaturante........................................ 38

3.1.6 Síntese da primeira fita de cDNA usando o Kit Seperscript II Preamplification system $\AA$ para RT-PCR (Gibco-BRL)............................ $\quad 39$

3.1.7 Reação de PCR para amplificação da sequencia específica correspondente àregião central do gene FtsH-p1 .............................. 39

3.1.8 Extração do fragmento desejado (região central) do gel de

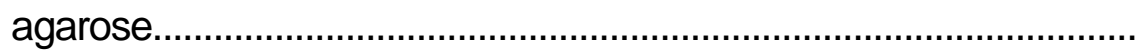

3.1.9 Clonagem do fragmento proveniente da reação de PCR (1272 pb) utilizando o Kit Sure Clone ${ }^{\mathrm{TM}}$ Ligation da Amersham Pharmacia Biotech.

3.1.9.1 Reação Blunting/Kinasing.............................................................

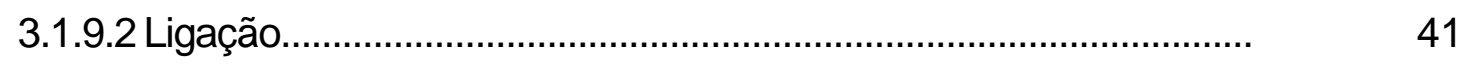

3.1.10 Preparação de células competentes de E. coli (JM 109) para transformação...........................................................................

3.1.11 Meios de culturas ..........................................................................

3.1.12 Transformação de E. coli (JM 109)............................................... 42

3.1.13 Avaliação da transformação ("screening" por PCR diretamente nas bactérias) 
das colônias selecionadas.

3.1.15 Sequenciamento do DNA dos clones obtidos.

3.1.16 Subclonagem do fragmento de $1272 \mathrm{pb}$ correspondente à

região central do gene FtsH-p1

3.1.17 Obtenção da extremidade 5' do gene FtsH-p1 àpartir do fragmento amplificado (1272 pb) utilizando o Kit 5' RACE (RAPID

AMPLIFICATION of cDNA ENDS) da Gibco-BRL

3.1.17.1 Isolamento do RNA total.

3.1.17.2 Síntese da primeira fita do cDNA.

3.1.17.3 Purificação do cDNA

3.1.17.4 Adição de uma cauda homolimérica (oligo-dC) na extremidade 3' do cDNA purificado utilizando a enzima Deoxinucleotidil

Transferase Terminal (TdT) 48

3.1.17.5 Reação de PCR com o cDNA dC-tailed. 48

3.1.18 Extração do fragmento 5' FtsH-p1 do gel de agarose.

3.1.19 Obtenção da extremidade 3' do gene FtsH-p1 àpartir do fragmento amplificado no item 3.1.9.

3.1.19.1 Isolamento do RNA total 49

3.1.19.2 Síntese da primeira fita do cDNA. 49

3.1.19.3 Reação de PCR para obtenção da região 3' FtsH-p1 de tomate..... $\quad 50$

3.1.20 Extração do fragmento 3' FtsH-p1 do gel de agarose.

3.1.21 Obtenção do cDNA completo da FtsH-p1 de tomate utilizando DNA polimerase de alta fidelidade..

3.1.21.1 Reação de PCR com a DNA polimerase Pfu.

3.1.22 Construções gênicas envolvendo a região amino-terminal da FtsHp1 e clonagem no vetor binário para transformação de plantas

3.1.22.1 Amplificação dos fragmentos.

3.1.22.2 Restrição dos fragmentos e do vetor de expressão em plantas.....

3.1.23 Ensaio de expressão transiente da GFP em células epidérmicas de 


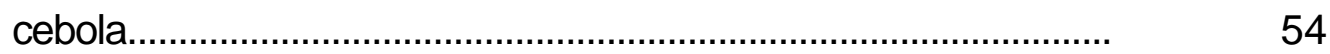

3.1.24 Transformação de Agrobacterium tumefaciens.................................. $\quad 55$

3.1.25 Transformação de plantas de Nicotiana tabacum com as construções pCAMBIA 35S-TP-GFP-NOS, pCAMBIA 35S-TP-H1GFP-NOS, pCAMBIA 35S-TP-H1-loop-GFP-NOS e pCAMBIA 35TP-H1-loop-H2-NOS ................................................................

3.1.26 Extração de DNA e verificação da presença do T-DNA nas plantas.. $\quad 56$

3.1.27 Expressão dos transgenes..............................................................

3.1.27.1 Extração de proteínas totais.........................................................

3.1.27.2 Análise da concentração de proteínas.......................................... 57

3.1.27.3 Eletroforese .........................................................................

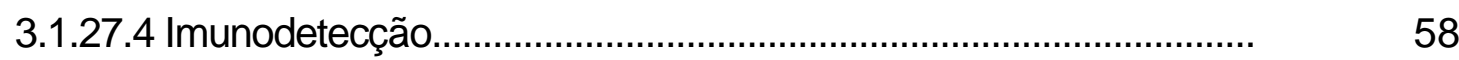

3.1.28 Isolamento de cloroplastos e tilacóides............................................ 59

3.2 Clonagem da região promotora do gene FtsH-p1, utilizando a técnica PCR-TAIL......................................................................................

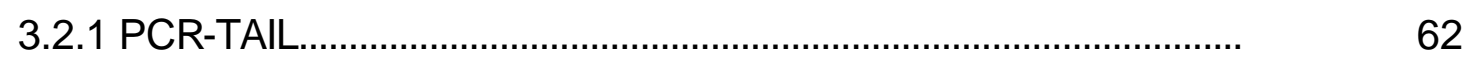

3.2.2 Clonagem e sequenciamento dos fragmentos obtidos nas reações PCR-TAIL e busca por motivos regulatórios........................................... 63

3.2.3 Deleções e clonagem dos fragmentos no vetor pCAMBIA 1281Z....... $\quad 64$

3.2.3.1 Construções gênicas envolvendo a região promotora da FtsH-p1 e clonagem no plasmídio binário para transformação de plantas

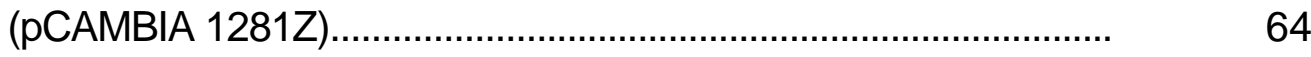

3.2.4 Expressão transiente e estável do gene uid $A$ (GUS)........................... 66

3.2.5 Ensaio histoquímico da enzima $\beta$-glucuronidase (GUS)...................... 66

3.2.6 Ensaio fluorimétrico da enzima $\beta$-glucuronidase (GUS)....................... 66

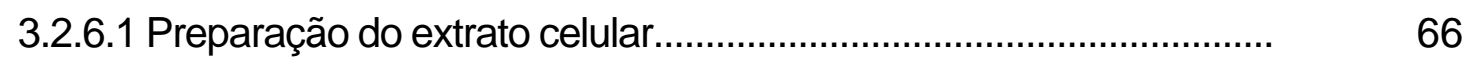

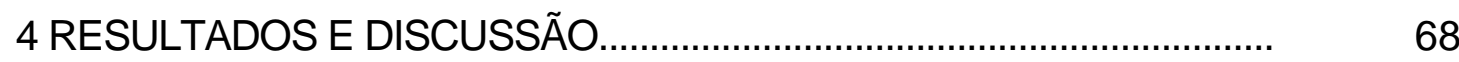

4.1 Análise das seqüências homólogas àFtsH em plantas superiores no 
Banco de Dados GenBanK.

4.2 Análise em Banco de dados.

4.3 Obtenção das extremidades 5' e 3' do gene FtsH-p1 via RACE (Rapid amplification of cDNA ENDs).

4.4 Obtenção do gene FtsH-p1 completo em uma única reação, utilizando uma DNA polimerase de alta fidelidade.

4.5 Domínios estruturais..

4.6 Localização subcelular da FtsH-p1 in vivo.

4.7 Expressão do transgene.

4.8 Localização intra-plastidial das proteínas de fusão.

4.9 Clonagem da região promotora do gene FtsH-p1, utilizando a técnica PCR-TAIL

4.10 Construções gênicas envolvendo a região promotora da FtsH-p1 e o gene uid A (GUS).

4.11 Regulação pela luz............................................................................ 92

4.12 Regulação por hormônios................................................................. 94

4.13 Efeito do $\mathrm{H}_{2} \mathrm{O}_{2}$ na expressão da FtsH-p1 ............................................ 100

4.14 Estresse salino e efeito temperatura .................................................... 102

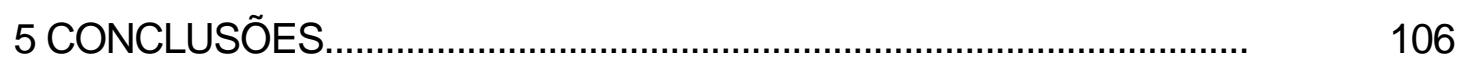

REFERÊNCIAS BIBLIOGRÁFICAS....................................................... 107 


\section{LISTA DE ABREVIATURAS}

$A A A=A T P a s e s$ associadas àdiversas atividades celulares

$\mathrm{ABA}=$ ácido abscísico

ATP $=$ trifosfato de adenosina

$\mathrm{BSA}=$ soro de albumina bovina

$\mathrm{cDNA}=$ DNA complementar

$\mathrm{ClpC}=$ chaperona cloroplástica

dNTP = deoxiribonucleotídeo trifosfato

ddNTP = di-deoxiribonucleotí deo trifosfato

D.O.600nm = densidade ótica à600 nanômetros

$\mathrm{DTT}=$ dithiotheitol

EST = seqüências expressas ("Expressed Sequence Tag")

EDTA $=$ etilenodiamina tetra acetato dissódico

GFP $=$ proteína verde fluorescente

GTP $=$ trifosfato de guanosina

GUS $=\beta$-glucuronidase

$\mathrm{Hsp}=$ proteína de choque térmico, chaperona

$\mathrm{kDa}=$ kilo Dalton

LTD = domínio de direcionamento tilacoidal

MPP $=$ metalopeptidase

$M U G=4-$ Metilumbeliferril $\beta-D$-glucuronide trietilamina

$\mathrm{MU}=$ 7-hidroxi-4-metilcoumarine

PAGE $=$ eletroforese em gel de poliacrilamida

$\mathrm{pb}=$ pares de bases

PBS = tampão fosfato salino 
$\mathrm{PCR}=$ reação de polimerase em cadeia

PSII = fotossistema II

$(\mathrm{p} / \mathrm{v})=$ peso/volume

$\mathrm{PVP}=$ polivinil pirrolidona

ROS = espécies reativas de oxigênio

$\mathrm{rpm}=$ rotações por minuto

SDS $=$ sódio dodecil sulfato

$\mathrm{Sec}=$ via de secreção

SPP $=$ peptidase de processamento estromal

$\mathrm{SRP}=$ partícula de reconhecimento do sinal

STD = domínio de direcionamento estromal

SUCEST $=$ Projeto Transcriptoma da cana-de-açucar

Tat $=$ via de translocação dependente de dupla arginina

TBS $=$ tampão Tris salino

T-DNA = DNA de transferência

TIC = translocase da membrana interna cloroplástica

TOC = translocase da membrana externa cloroplástica

Tris $=$ Tris(hidroximetil)aminometano

Tween $=$ polioxietilenosorbitol

$(\mathrm{v} / \mathrm{v})=$ volume/volume

$X$-Gluc $=5$-bromo-4-cloro-3-indol $\beta$-D-glucuronide ciclohexilamino 


\title{
CLONAGEM, CARACTERIZAÇÃO DA EXPRESSÃO GÊNICA E DO TRANSPORTE INTRA-ORGANELAR DA PROTEASE FtsH-p1 DE TOMATE (Lycopersicon esculentum Mill. cv. MicroTom)
}

\author{
Autor: REINALDO MONTRAZI BARATA \\ Orientador: Prof. Dr. MARCIO DE C. SILVA FILHO
}

\section{RESUMO}

A protease $\mathrm{FtsH}$ pertence à superfamília das proteínas AAA (ATTPases Associadas à diversas $\underline{A}$ tividades celulares) cujos membros estão amplamente distribuídos entre procariotos e eucariotos. Nas plantas superiores, elas são codificadas por genes nucleares e sintetizadas por ribossomos citosólicos com uma seqüência de direcionamento na extremidade aminoterminal responsável pela translocação da pré-proteína para o interior das organelas, notadamente mitocôndrias e cloroplastos. Com o objetivo de caracterizar o processo de translocação da proteína aos tilacóides e sua regulação gênica em plantas, isolou-se um cDNA de frutos de tomate (Lycopersicon esculentum Mill. cv. MicroTom), cuja seqüência de aminoácidos revela a presença de todos os motivos clássicos pertencentes a uma protease do tipo FtsH-p1. A caracterização inicial da proteína indicou a presença de um típico peptídeo de trânsito cloroplástico em sua extremidade amino-terminal. A fim de definir qual região da proteína madura está envolvida no direcionamento da protease æ̀̀ membranas, foram realizadas construções gênicas contendo 
diferentes comprimentos da região amino-terminal da FtsH-p1 de tomate fusionados ao gene repórter GFP (green fluorescent protein). Estudos realizados a partir de frações enriquecidas de cloroplastos, estroma e tilacóide, provenientes de plantas transgênicas expressando estavelmente estas construções, revelaram que todas as proteínas de fusão acumularam-se no estroma sendo, portanto incapazes de associarem-se aos tilacóides. Estes dados indicam que a inserção da FtsH-p1 de tomate nas membranas dos tilacóides dependem de informação presente na proteína madura, necessária para a interação com as membranas ou mesmo com um fator adicional desconhecido. Alem disso, foi mostrado que membros da família das proteases do tipo das FtsHs em plantas não apresentam o clássico motivo RRXFLK, previamente descrito como essencial para a translocação dependente de uma dupla arginina (Tat). Devido ao envolvimento de ortólogos desta proteína em processos fisiológicos importantes nas plantas, abriu-se a possibilidade de estudar a regulação da FtsH-p1 de tomate via clonagem e caracterização da sua região promotora. Uma vez clonada, 4 deleções à partir da extremidade 5' nesta região foram realizadas e fusionadas de forma a dirigirem a expressão do gene repórter uidA (GUS). Estas construções foram expressas estavelmente em plantas de tabaco, a fim de estudar sua regulação em diferentes tecidos, estádios de desenvolvimento e em resposta a estímulos ambientais ou situações de estresse. Os resultados preliminares mostraram que a seqüência regulatória clonada é responsível tanto à fatores ambientais, como luz, quanto aos hormônios auxina, citocinina e giberelina. Além disso, foi observada uma regulação negativa na presença de peróxido de hidrogênio. Entretanto, tratamentos envolvendo estresse salino, bem como variações na temperatura não geram nenhum efeito na atividade da enzima GUS. O mesmo ocorre quando as plantas ฐ̃o colocadas em presença de ácido abscísico (ABA). Os resultados deste estudo contribuem significativamente para um melhor entendimento dos mecanismos de regulação envolvidos no controle da 
expressão gênica da FtsH-p1 de tomate, bem como sugerem novas perspectivas no direcionamento de proteínas à membranas. 


\title{
MOLECULAR CLONING, CHARACTERIZATION OF THE GENE EXPRESSION AND INTRA-ORGANELLAR TRANSPORT OF TOMATO (Lycopersicon esculentum Mill. cv. MicroTom)
}

\author{
Author: REINALDO MONTRAZI BARATA \\ Adviser: Prof. Dr. MARCIO DE C. SILVA FILHO
}

\section{SUMMARY}

The FtsH protease belongs to the AAA family (ATPases associated with different cellular activities) whose members are widely distributed in prokaryotes and eukaryotes. In higher plants, these proteins are nuclearencoded and synthesized by cytosolic ribosomes as larger molecular weight precursors. These molecules carry at the $\mathrm{N}$-terminal extension a specific targeting sequence that directs translocation of the preproteins to the envelope membranes of mitochondria and chloroplasts. In the present work, a tomato (Lycopersicon esculentum Mill. cv. MicroTom) fruit cDNA encoding a plastid FtsH-p1 has been isolated, cloned and characterized. In order to define the protein domains involved on thylakoid targeting, several gene constructions were prepared carrying increasing lengths of the Nterminal region of tomato FtsH fused to the gfp (green fluorescent protein) reporter gene. In vivo expression studies based on onion cells or stable expression in transgenic tobacco plants showed that the chimeric proteins were translocated to plastids. 
In addition, sub-organellar fractionation indicated that GFP accumulated in the stromal fraction, instead of being translocated to the thylakoid membrane. These data suggest that membrane insertion of tomato $\mathrm{FtsH}-\mathrm{p} 1$ requires information present in the mature protein. One remarkable finding was that members of the FtsH family do not present the classical RRXFLK motif, that has been shown to be essential for the Tat-dependent pathway. The FtsH-family members are involved in important physiological processes in plant cells. Therefore, this study opened up the possibility of studying the FtsH-p1 gene regulation by characterization of its regulatory region. After cloning a $1700 \mathrm{bp}$ fragment corresponding to 5' upstream region of the tomato $\mathrm{FtsH}$ coding sequence, four deletions of the promoter region were performed and the resulting fragments were fused to the uidA (GUS) reporter gene. These gene constructs were stable expressed in tobacco plants and further characterized. The results showed that the promoter region is positively regulated by light and the phytohormones auxin, cytokine and gibberelin. Besides, the promoter was down regulated by hydrogen peroxide. However, GUS activity was not affected by salt stress, variations on the temperature and abcisic acid treatment. The results presented here expand the current understanding of factors involved on FtsH gene regulation as well as bring new insights on the protein targeting to membranes. 


\section{INTRODUÇÃO}

Um importante mecanismo envolvido no controle da expressão gênica é a degradação de proteínas regulatórias via proteases celulares (Adam, 2001). Vários trabalhos têm mostrado que os membros pertencentes à família

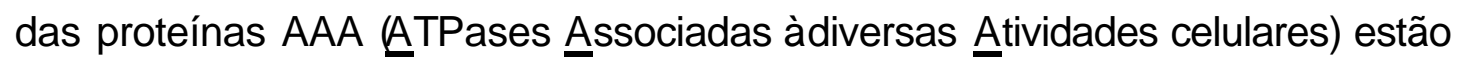
envolvidos em diferentes processos do metabolismo celular como por exemplo, transporte de proteínas, divisão celular, formação do peroxissomo e, principalmente, na degradação de proteínas (Leonhard et al., 1996).

Um dos membros procarióticos da família é representado pela proteína FtsH de Escherichia. coli. A FtsH corresponde a uma proteína integral de membrana de aproximadamente $71 \mathrm{kDa}$, que apresenta um domínio ATPásico em sua extremidade carboxi-terminal essencial para o funcionamento na célula. Além de participar no transporte de proteínas através das membranas, a FtsH também participa na degradação (dependente de zinco) de diferentes peptídeos citoplasmáticos ou associados à membranas (Tomoyasu et al., 1995).

Em leveduras, três diferentes proteínas homólogas às FtsH já foram caracterizadas, e estão localizadas no interior das mitocôndrias (Leonhard et al., 1996). Uma classe particular de proteases cloroplásticas semelhantes à FtsH bacteriana tem sido caracterizada em plantas. Esta protease é codificada por um gene nuclear e direcionada aos cloroplastos via uma seqüência de direcionamento específica (Lindhal et al., 1996).

Em plantas de pimentão já foram caracterizados diferentes cDNAs que codificam para proteínas da família AAA. Dois deles correspondem a proteases cloroplásticas do tipo bacteriano (FtsH), notadamente bcp e cacp (G. Houlné, comunicação pessoal). Uma observação interessante feita pelo pesquisador é que uma das proteases (BCP) apresenta uma seqüência de 
direcionamento com algumas propriedades semelhantes as proteínas direcionadas æ̀ mitocôndrias, apesar de ser encontrada associada aos tilacóides no interior dos cloroplastos. Este fato levantou a hipótese da existência destas proteínas em mitocôndrias de plantas superiores.

Nos últimos anos, inúmeros trabalhos tem caracterizado o transporte de proteínas dentro dos cloroplastos, notadamente os mecanismos responsáveis pela translocação de proteínas aos tilacóides (Robinson et al., 2000; Woolhead et al., 2000). Atualmente, são conhecidos 4 mecanismos distintos encarregados de direcionar proteínas aos tilacóides e são definidos em função dos substratos específicos de cada sistema, assim denominados: via de inserção espontânea, dependente de SRP, via Sec e dependente de Tat (Robinson et al., 2000).

A caracterizacão de um membro da família das FtsHs em pimentão (Pftf) revelou que esta proteína utiliza o sistema de transporte Tat (baseado numa dupla-arginina). Ao analisar outros membros da família das FtsHs, foi identificado que algumas proteases não apresentavam o motivo característico. Assim sendo, tornou-se importante caracterizar o mecanismo de direcionamento æ̀ membranas bem como sua regulação gênica. $O$ entendimento destes importantes aspectos relacionados a esta classe de proteínas poderá trazer subsídios para o conhecimento de sua função e do processo de transporte de proteínas à membranas. 


\section{REVISÃO DE LITERATURA}

Um importante mecanismo envolvido no controle da expressão gênica é a degradação de proteínas regulatórias via proteases celulares. Entretanto, apesar desse processo estar bem documentado em bactérias, pouco se sabe sobre os mecanismos regulatórios e a identidade das proteases vegetais. Sabemos que o período de atividade da maior parte das proteínas é significativamente mais curto do que o tempo de vida dos organismos que as produzem. Esse fato é de extrema necessidade, pois assim, as plantas conseguem, através da proteólise, controlar muitos aspectos da regulação celular, principalmente no que diz respeito à fotomorfogênese, ciclo celular, fotossíntese, morte celular programada, ritmo circadiano e respostas de defesa. Algumas proteínas são degradas quando danificadas (danos conformacionais ou danos covalentes) ou por processos inerentes ao metabolismo celular ou mesmo no processo de tradução e montagem (Schumann, 1999). Outras são degradadas quando seu blocos de construção (átomos de carbono e nitrogênio) são requeridos para suportar a vida do organismo. Ainda outras, são degradas em resposta a sinais celulares e ambientais específicos. Em todos os casos, a proteólise é um processo altamente específico e regulado e acompanhado por uma coleção de diversas proteases (Estelle, 2001).

\subsection{Proteases}

Proteases são enzimas que hidrolisam ligações peptídicas e podem ser divididas em dois grandes grupos tomando-se como base a forma 
de ataque da cadeia polipeptídica. As PROTEINASES ou ENDOPEPTIDADES apresentam a propriedade de reconhecer o sítio de clivagem na região interna da proteína alvo gerando, dessa forma, dois grandes peptídeos. O outro grupo é representado pelas PEPTIDASES ou EXOPEPTIDASES que iniciam 0 processo de degradação a partir das extremidades (amino ou carboxi-terminal) das proteínas produzindo pequenos peptídeos ou mesmo aminoácidos. Por sua vez, as PROTEINASES podem ser subdivididas tomando-se como base 0 grupo reativo presente no sítio ativo envolvido na catálise em serino-, cisteíno-, aspártico-e metalo-proteinases (Ryan, 1990).

\subsubsection{Proteases AAA}

A família das proteínas AAA (ATPases Associadas à diversas Atividades celulares) representa uma subfamília do grupo das ATPases do tipo Walker, ou seja, apresentam dois motivos ou domínios ATPásicos bastante conservados, o Walker A e ○ Walker $\mathrm{B}$, responsáveis pela sua atividade ATPásica (Karata et al., 1999). Além de possuírem os dois motivos Walker apresentam outra seqüência de aminoácidos bastante conservada dentro do domínio ATPásico denominada de segunda região de homologia (SRH). Essa seqüência de 200-250 aminoácidos, que engloba tanto os motivos Walker $A$ e $B$ quanto o $\mathrm{SRH}$, é denominado de módulo $\mathrm{AAA}$ e é o que diferencia a família AAA das outras ATPases do tipo Walker (Karata et al., 1999). Dessa forma, proteases AAA são caracterizadas pela presença de uma ou duas cópias do módulo AAA.

Vários trabalhos têm mostrado que os membros pertencentes à família das proteínas AAA estão envolvidos em diferentes processos do metabolismo celular como por exemplo, transporte de proteínas, divisão celular, formação do peroxissomo e, principalmente, na degradação de proteínas em bactérias, mitocôndrias e cloroplastos (Leonhard et al., 1996; Langer, 2000 e Lupas \& Martin, 2002). Atualmente, a família AAA pode ser dividida em 
subfamílias: as metaloproteases, as subunidades do proteassomo 26S, proteínas envolvidas na secreção através da formação de vesículas, na fusão homotípica, na biogênese dos peroxissomas, na meiose e funcionamento das mitocôndrias (Marbach et al, 2001).

\subsubsection{FtsH - uma metaloprotease AAA bacteriana}

Um dos membros procarióticos da família AAA é representado pela proteína FtsH (filamentation temperature-sensitive) de Escherichia coli. A FtsH corresponde a uma proteína integral de membrana de aproximadamente $71 \mathrm{kDa}$ que apresenta dois segmentos transmembrana (TM1 e TM2) em sua região N-terminal seguido por um domínio citoplasmático (C-terminal) (Tomoyasu et al, 1993) contendo uma cópia do módulo AAA e um motivo conservado de ligação à $\mathrm{Zn}^{+2}(\mathrm{HEXGH})$ que é responsável pelo sítio catalítico da proteólise (figura 1)

Vários substratos da FtsH têm sido identificados e entre eles destacam-se proteínas citoplasmáticas tais como o fator transcricional "heat shock" $\sigma^{32}$, as proteínas CII e CIII (ativadores transcricionais) do fago $\lambda$ que são extremamente importantes nas etapas de estabelecimento da lisogenia e proteínas integrais de membrana tais como SecY (junto com SecE e SecG formam um translocom pelo qual as proteínas citoplasmáticas são secretadas) e a subnidade $\alpha$ da $\mathrm{H}^{+}$ATPase (Karata et al., 1999). Além de ser uma protease, há evidências circunstanciais de que a FtsH também age com uma chaperona molecular (associa-se com a fosfatase alcalina desnaturada sem degradá-la), influenciando tanto na montagem quanto na localização (disposição) de diversas proteínas. Portanto, a FtsH em E. coli pode servir como mantenedora do controle de qualidade de algumas proteínas citoplasmáticas e de membrana. Tais proteases dependentes de ATP que mostram atividade intrínsica de chaperona tem sido designadas pela literatura por charoninas (Schumann, 1999). 
a)

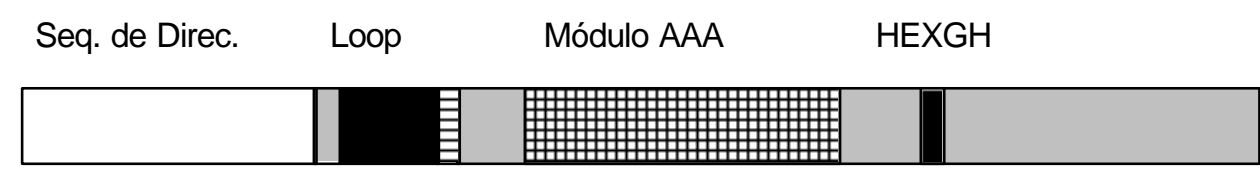

TM1 TM2

Lig. $\mathrm{Zn}^{+2}$

b)

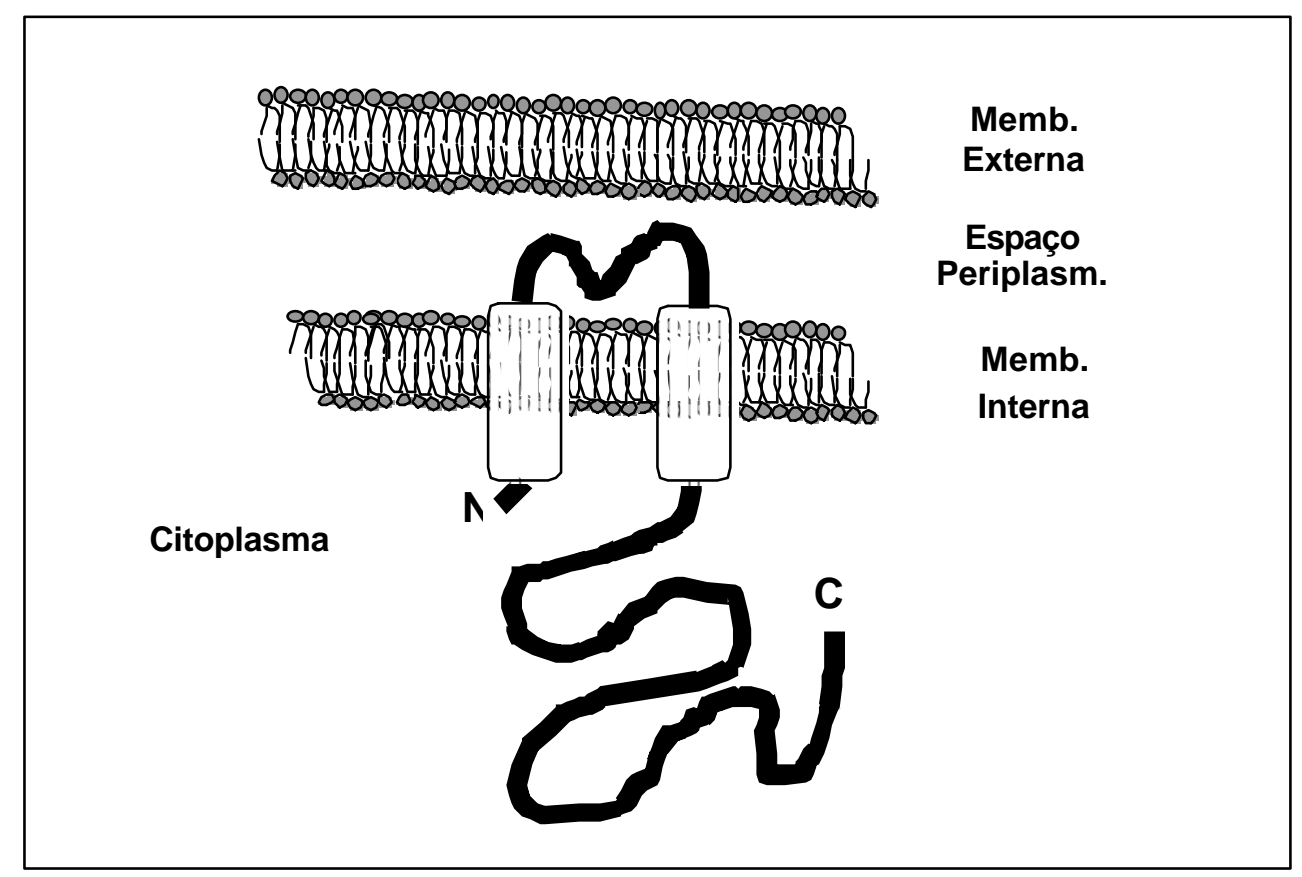

Figura 1 - a) Diagrama representativo da metaloprotease FtsH de E. coli. O módulo AAA engloba os motivos Walker $A$ e Walker $B$ e a $\mathrm{SRH}$. b) Esquema mostrando a disposição da $\mathrm{FtsH}$ na membrana plasmática (região carboxi-terminal exposta para a região citoplasmática.

Fonte: Adaptado de Langer (2000) 


\subsubsection{FtsHs em leveduras}

Em leveduras (S. cerevisae), três diferentes proteínas homólogas à FtsH (Yme1p, Yta10 e Yta12) já foram caracterizadas e estão localizadas no interior das mitocôndrias. Estas três proteínas fazem parte de dois complexos (m-AAA e i-AAA) com atividade proteásica, e apresentam uma atividade do tipo chaperona e cooperam entre si para degradação de proteínas da membrana mitocondrial (Leonhard et al., 1996). Muito pouco é conhecido sobre a estrutura destes complexos bem como a estequiometria de suas subunidades. Contudo, por analogia com outras proteínas $\mathrm{AAA}$, provavelmente elas trabalham como estruturas hexaméricas (Langer et al., 2001). Este processo de oligomerização parece crucial para a atividade proteolítica, presumivelmente porque os resíduos de aminoácidos das subnidades vizinhas estão envolvidos na ligação da molécula de ATP aos módulos AAA (Langer, 2000). A protease m-AAA expõe seu sítio catalítico na matriz mitocondrial e é composta pelas subunidades Yta10 e Yta12 que parecem estar presentes em quantidades equimolares. A protease i-AAA é composta por um complexo oligomérico de subunidades Yme1p, cujos sítios catalíticos estão expostos para o espaço intermembranoso (figura 2). Células de levedura deficientes na protease i-AAA mostram um aumento na taxa de escape de DNA mitocondrial e apresentam deficiências respiratórias em temperaturas elevadas (Thorsness et al., 1993). Por outro lado, a protease m-AAA é necessária para a eficiente montagem dos complexos proteicos mitocondriais (Arlt et al., 1998). 


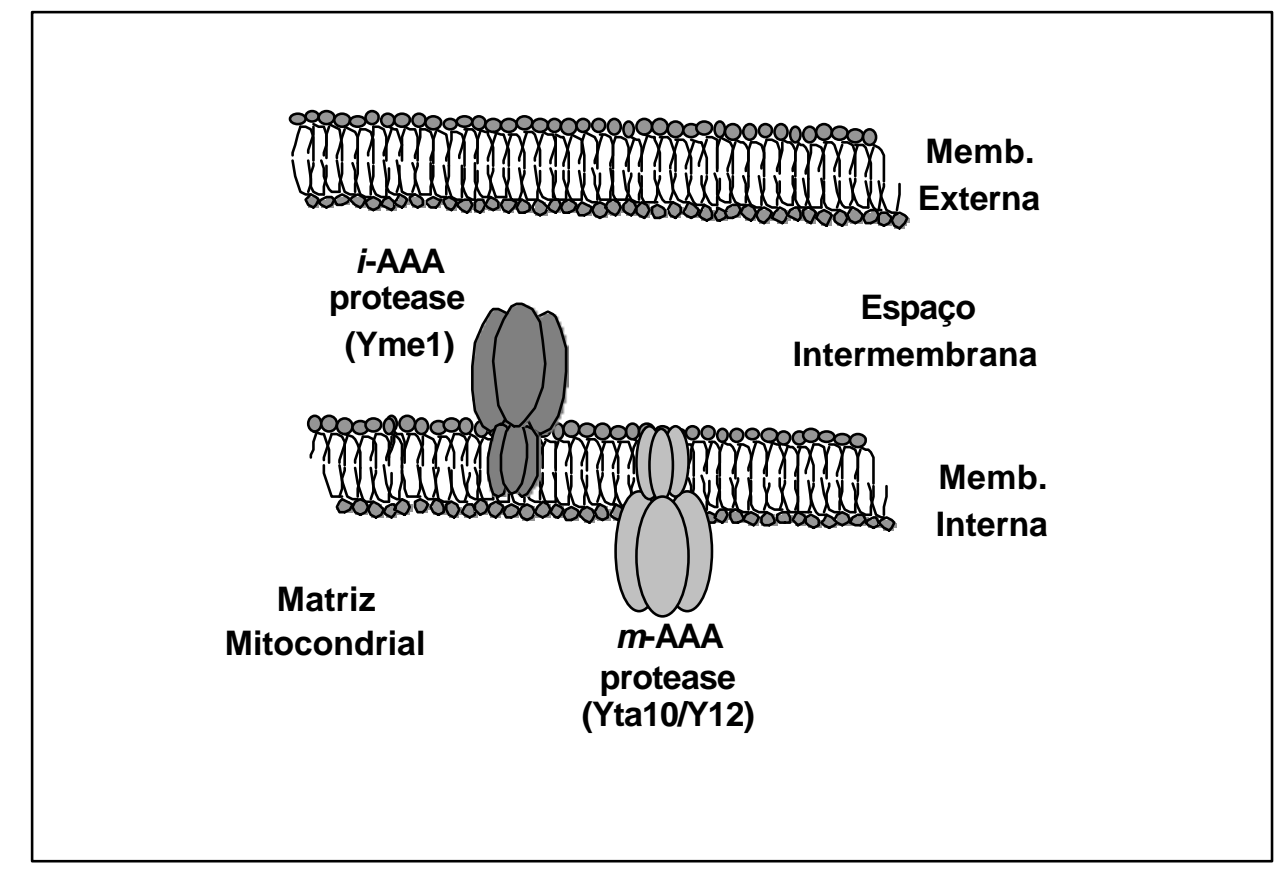

Figura 2 - Esquema mostrando que em mitocôndrias de leveduras, as regiões carboxi-terminais das FtsHs, ficam voltadas para o espaço intermembranoso (i-AAA) e para a matriz mitocondrial ( $m$-AAA).

Fonte: Adaptado de Langer (2000)

\subsubsection{Proteínas AAA em plantas superiores}

A família das proteínas AAA participa, como mencionado anteriormente, de forma ubiquitária de uma série de funções celulares ao longo do desenvolvimento, sendo que cada membro desempenha um papel específico.

A existência de uma proteína homóloga à FtsH no interior dos cloroplastos foi primeiro demonstrada por Lindahl e colaboradores, (1996) quando um anticorpo específico para a FtsH de $E$. coli reconheceu uma proteína de aproximadamente 71 kDa em frações enriquecidas de tilacóides de 
espinafre. Os autores, acreditavam que deveriam encontrar proteases semelhantes as procarióticas no interior de plastídeos e mitocondrias devido a teoria da origem endosimbiótica destas organelas. Subseqüentemente, um cDNA de Arabidopsis foi isolado e mostrou extensiva homologia com a FtsH bacteriana. Estudos mais detalhados envolvendo topologia, sugeriram que esta FtsH era uma proteína integral de membrana dos tilacóides cuja porção carboxiterminal (região hidrofílica), contendo os domínios ATPásicos e de metaloprotease dependente de zinco, estavam mergulhados na região estromal clivando potenciais substratos, tanto da fração solúvel quanto aqueles associados æ̀ membranas. (Bailey et al., 2001). Após a descoberta da FtsH cloroplástica, Ostersetzer \& Adam (1997) mostraram que a protease FtsH, é a responsável direta pela degradação de formas solúveis e associadas à membranas das proteínas Reiske Fe-S (subunidade do complexo citocromo b/f) que não foram montadas em suas conformações corretas. Eles também mostraram que essa degradação era totalmente dependente do metal zinco e reações onde anticorpos reconheciam a FtsH-1 apresentavam inibição do processo degradativo. Também especulava-se, que a $\mathrm{FtsH} 1$ poderia estar implicada na degradação do polipeptídeo D1 do fotossistema II (ver abaixo).

Posteriormente, a existência de uma segunda FtsH cloroplástica foi reportada em plantas superiores com a descoberta das mutações var 2, que são mutações no gene que codifica para um ortólogo da FtsH-1 (Takechi et al., 2000; Chen et al., 2000) e é responsável por ocasionar variegação foliar em Arabidopisis. O gene var 2 é ortólogo ( $43 \%$ de identidade) mas não alélico ao gene clonado por Lindhal et al., (1996). Por outro lado, uma série alélica dos mutantes var 2 foi caracterizada por Chen e colaboradores (2000). Entre estes, o var2-1 e var2-2 são os alelos mais severos, cujo fenótipo mostra folhas predominantemente brancas com a formação de pequenas ilhas esverdeadas. A emergência de setores verdes no lugar de um fenótipo completamente albino pode ser explicada pelo fato de que a FtsH compreende, em Arabidopsis e outras espécies de plantas superiores, uma pequena família gênica (Adam 
2001; Marbach et al., 2001). Sendo assim, tal redundância genética poderia tolerar a deficiência da proteína VAR2, e por isso originar um fenótipo com características não letais. Além disso, Chen e colaboradores (2000) concluíram que os homólogos da FtsH-VAR2 estão envolvidos nas etapas de desenvolvimento dos cloroplastos possivelmente em um ou mais processos da biogênese das membranas dos tilacóides. Paralelamente, Takechi e colaboradores (2000), apresentaram conclusões similares propondo que os homólogos da FtsH-VAR2 seriam requeridos para regulação, ao longo do desenvolvimento, da formação e manutenção de membranas no interior de plastídeos e, além disso, especularam que elas poderiam estar envolvidas na degradação de complexos protéicos danificados por foto-oxidação. Entretanto, os mecanismos precisos que geram o fenótipo variegado nas plantas var2 permanecem sem explicação segundo Sakamoto e colaboradores (2002).

Um grande número de sequências semelhantes à FtsH tem sido identificadas nos mais variados organismos (muitas delas são "Expressed Sequence Tags", ESTs). Porém as funções desempenhadas por estas proteínas são ainda obscuras (Beyer, 1997). Uma das principais razões para este fato refere-se a falta de mutantes para estas seqüências em eucariotos superiores. Em plantas, a FtsH-1 e a VAR2 são as únicas proteínas da família das FtsHs que têm sido estudadas em mais detalhes. Contudo, o fato de que essas seqüências não apresentem uma alta similaridade principalmente na região Cterminal, sugerem que essas proteínas apresentam especificidades distintas. Esse fato foi reforçado quando plantas manipuladas geneticamente de forma que a expressão da $\mathrm{FtsH}-1$ era extremamente baixa, não mostraram o fenótipo variegado (Sakamoto et al., 2002).

Em um estudo interessante, o gene Pfff foi isolado em 1995 por Hugueney e colaboradores como um fator solúvel que estava associado com a diferenciação de cloroplastos em cromoplastos durante o processo de amadurecimento de frutos de pimentão. Devido ao fato da Pftf ter sido isolada como um fator solúvel, pensou-se naquela ocasião tratar-se de uma proteína 
estromal. Contudo, Summer \& Cline (1999) mostraram que a Pftf era, na realidade, uma proteína de membrana e apresentando alta similaridade com a protease VAR2. Assim sendo, elas foram classificadas como sendo da mesma linhagem e apresentam funções e atividades similares.

A fim de melhor caracterizar a função das FtsHs no interior dos cloroplastos, alguns grupos de pesquisa concentraram-se no possível envolvimento desta protease na degradação da proteína D1 (componente do fotossistema II (FSII) que, sabidamente participa de forma preponderante no processo de fotoinibição. A fotoinibição tem início quando a planta é exposta a condições de alta luminosidade e espécies reativas de oxigênio, que são rapidamente formadas, danificam a proteína D1 de maneira irreversível. Este polipeptídeo é muito sensível ao dano fotoxidativo apresentando a maior taxa de renovação (turnover) quando comparado à outras proteínas tilacoidais (Mattoo et al., 1989). Como forma de reparar os danos causados pelos efeitos das espécies reativas de oxigênio (ROS), um mecanismo de reparo da proteína D1 altamente coordenado ocorre no interior dos cloroplastos no sentido de restabelecer esta proteína (Melis, 1999). É provável que esse processo ocorra anteriormente àremoção proteolítica da proteína danificada.

Após a fotoinativação, a degradação da proteína D1 procede-se por um mecanismo que envolve dois passos (Estelle, 2001). O primeiro é uma clivagem endoproteolítica no "loop" estromal que conecta as hélices D e E da proteína na membrana, produzindo um fragmento aminoterminal de $23 \mathrm{kDa}$ e um carboxiterminal de $10 \mathrm{kDa}$. A protease responsável por catalisar essa reação e o local exato da clivagem ainda são desconhecidos. Após esta primeira clivagem, os fragmentos da proteína D1 são rapidamente degradados. Por outro lado, o envolvimento da protease $\mathrm{FtsH}-1$ na proteólise do fragmento de $23 \mathrm{kDa}$ foi mostrado experimentalmente. Lindahl e colaboradores (2000), trabalhando com membranas tilacoidais isoladas, mostraram que o peptídeo de 23 kDa da proteína D1 acumulou após tratamento fotoinibitório. Contudo, esse acúmulo era bastante diminuído quando adicionava-se ao meio de reação 
quantidade crescentes de ATP e zinco, mostrando o possível envolvimento da protease FtsH neste processo. Para realmente constatar o envolvimento desta protease, os autores superexpressaram e purificaram a proteína $\mathrm{FtsH}-1$ de Arabidopsis em E. coli. A proteína isolada era proteoliticamente ativa e sensível a inibidores de metaloproteases. Assim, quando complexos do fotossistema II desprovidos de $\mathrm{FtsH}$ foram isolados e iluminados, o fragmento de $23 \mathrm{kDa}$ acumulou-se. Por outro lado, quando estes mesmos complexos foram colocados em contato com a $\mathrm{FtsH}-1$ recombinante na presença de ATP a degradação do fragmento foi observada. Dessa forma, esses resultados confirmaram o envolvimento da $\mathrm{FtsH}-1$ no processo degradativo do fragmento de 23 kDa da proteína D1 (figura 3)

Recentemente, Bailey e colaboradores (2002) tentando solucionar a questão sobre a natureza da protease envolvida na primeira clivagem proteolítica da proteína D1, mostraram, in vivo, o envolvimento da FtsH-VAR2. Mutações no loco var2, como visto anteriormente, geram plantas com o fenótipo variegado devido a problemas inerentes à biogenese e remanejamento das membranas dos tilacóides realizado pelas FtsHs. Dessa forma, os setores verdes destas plantas mutantes (var2) tornam-se instrumentos valiosos para 0 estudo da função das FtsHs pois apresentam cloroplastos morfologicamente normais apesar da falta da VAR2 (a mutação var2 não mostra acúmulo da proteína VAR2 nas membranas dos tilacóides devido a uma mutação no final do segundo domínio transmembrana) (Bailey et al., 2001). Os autores mostraram ainda que a proteína D1 danificada não sofre, nestes mutantes, a clivagem inicial gerando assim, plantas mais sensíveis àfotoinibição.

A fim de isolar genes envolvidos na resposta hipersensível, Seo e colaboradores (2000), trabalharam com cultivares de Nicotiana tabacum resistentes a infecção pelo vírus TMV (vírus do mosaíco do tabaco). Estas plantas apresentam, após a infecção, morte celular das células infectadas acompanhadas pela formação de lesões necróticas. Destes experimentos, os 
autores isolaram um cDNA (DS9) que codifica para uma proteína homóloga à FtsH-1 que é encontrada em grande abundância em células saudáveis.

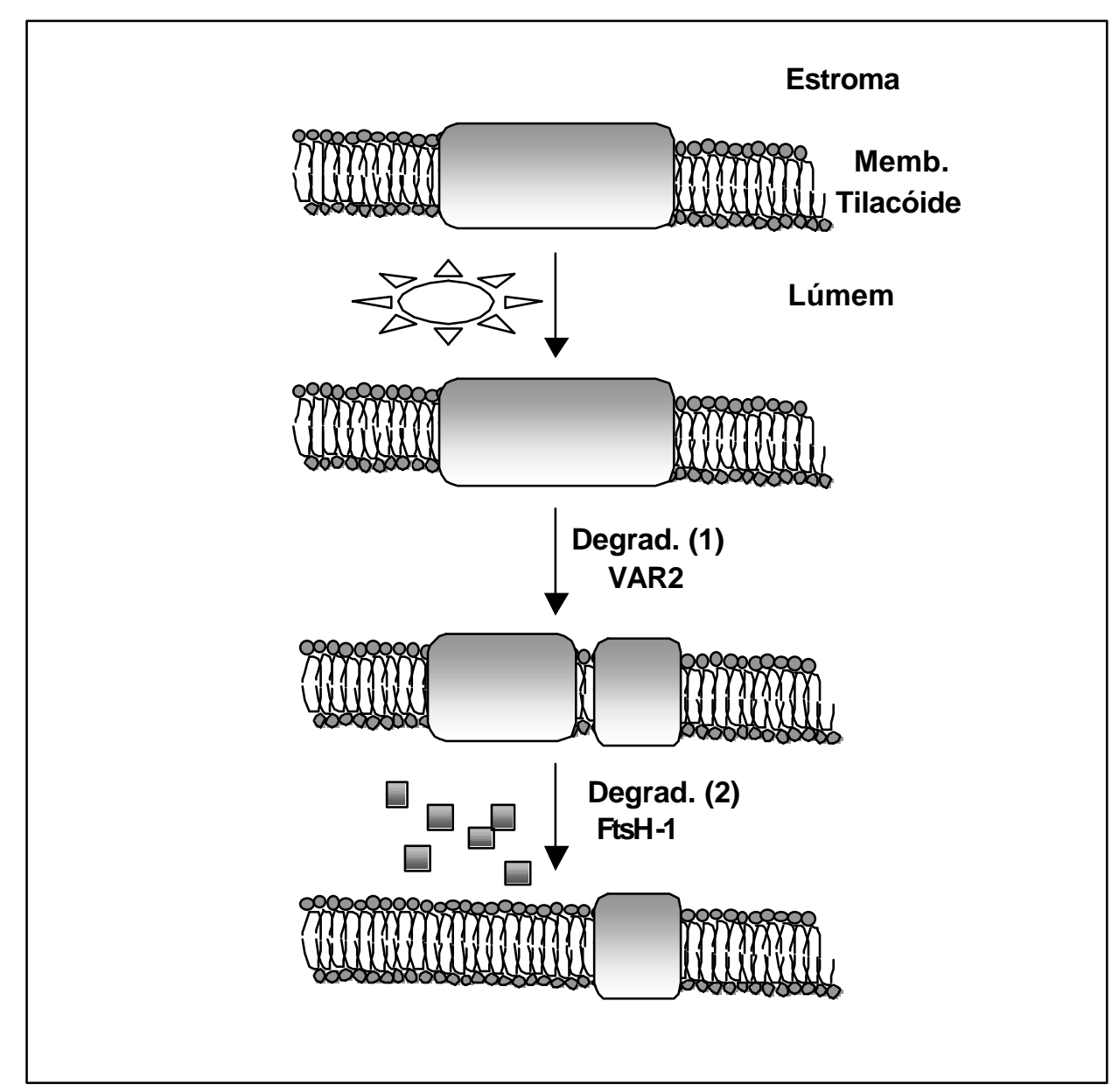

Figura 3 - Esquema mostrando o modelo de degradação da proteína D1 após o dano fotooxidativo. A proteína danificada sofre uma primeira clivagem pela protease FtsHVAR2 (dependente de GTP) gerando dois fragmentos (23 e $10 \mathrm{kDa}$ ). Posteriormente, o fragmento de 23 $\mathrm{kDa}$ é degradado pela FtsH-1.

Fonte: Adaptado de Estelle (2001) 
Porém, sua expressão é bastante baixa (antes das lesões necróticas) nas células infectadas pelos vírus. Os autores mostraram que plantas transgênicas superexpressando esta proteína apresentavam lesões necróticas mais evidentes do que as plantas com expressão diminuída ao serem infectadas pelo vírus. Os dados confirmaram que a diminuição do nível de expressão da DS9 (FtsH-1) em plantas infectadas pelo TMV, resultavam na perda de função dos cloroplastos (a proteína D1 não era restaurada) acelerando a resposta hipersensível e consequentemente a morte celular. Essa foi a primeira demonstração do envolvimento ds FtsHs no processo de morte celular.

Com o objetivo de estudar a regulação gênica da FtsH-1 em alfafa (Medicago sativa), Ivashuta e colaboradores (2002) analisaram sua expressão sob diferentes condições experimentais. Plantas de alfafa cultivadas sob condições de baixas temperaturas $\left(2^{\circ} \mathrm{C}\right)$ ou alta luminosidade mostraram elevados níveis tanto de mRNA quanto de proteínas $\mathrm{FtsH}-1$ mostrando que a expressão desse gene é regulada positivamente por estas duas condições. Os autores observaram ainda que $\mathrm{o}$ aumento da expressão da $\mathrm{FtsH} 1$ sob condições de baixa temperatura era bastante intrigante e provavelmente seria resultado de um efeito compensatório. Sob condições de baixa temperatura, a cinética de degradação do fragmento da proteína D1 (23 kDa) é bastante diminuída em membranas isoladas de tilacóides de Arabidopsis, sugerindo uma reduzida atividade proteolítica da $\mathrm{FtsH}-1$. Sendo assim, níveis elevados da FtsH-1 sob baixas temperaturas deveriam compensar a atividade diminuída da enzima (Haussuhl et al., 2001). Os autores sugerem ainda que o acúmulo da proteína FtsH-1 não faz parte da resposta geral àcondições de estresse, desde que tratamentos com $\mathrm{NaCl}, A B A$ ou mesmo dissecação não mostraram nenhuma alteração no nível de expressão desse gene. Por outro lado, o nível de transcritos diminuiu significativamente quando as plantas foram colocadas sob regime de alta temperatura $\left(42^{\circ} \mathrm{C}\right)$. Os autores também relatam que a indução da FtsH-1 pela luz e pelo frio são eventos completamente independentes pois eles conseguiram detectar uma elevação no nível de 
transcrição da FtsH1 em plântulas que cresceram no escuro sob baixa temperatura.

Em 2001, um grupo de pesquisadores trabalhando com proteases de organelas propôs uma nova classificação devido ao rápido acúmulo de seqüências de DNA clonadas em bancos de dados (Adam et al., 2001). Nesta oportunidade, no banco genômico de Arabidopsis foram encontradas nove seqüências homólogas a protease FtsH pelos autores. Duas isoformas, como visto anteriormente (FtsH1 e FtsH-VAR2=FtsH2), foram encontradas no interior de cloroplastos como proteínas integrais de membranas, com seus domínios ATPásicos e de ligação ao metal zinco faceando o estroma (Lindahl et al., 1996; Chen et al., 2000). Quatro parálogos adicionais, FtsH-5 à FtsH-8 foram preditos (análise in silico) como sendo localizados nos cloroplastos, enquanto a FtsH-3 era predita localizar-se no interior de mitocôndrias. A localização da $\mathrm{FtsH}-4$ não pôde ser predita com os programas disponíveis embora análise filogenéticas mostrassem que seu homólogo mais próximo era uma das três FtsHs mitocondriais de levedura. A FtsH-9 era um cDNA parcial cuja localização não podia ser predita a partir da seqüência disponível, embora naquela oportunidade isso pudesse ser solucionado pela eventual busca de sua seqüência completa no banco genômico. Os autores encontraram outras seqüências homólogas à $\mathrm{FtsH}$, porém elas foram excluídas do processo de classificação por não possuírem o domínio conservado de ligação ao metal $\mathrm{Zn}^{+2}$.

Posteriormente, Marbach e colaboradores (2001) realizaram uma análise filogenética das FtsHs procariontes e de eucariontes (total de 41 seqüências) utilizando-se o dados depositados no GeneBank (NCBI) e dados obtidos junto ao projeto SUCEST da FAPESP. Neste trabalho, os autores descrevem pela primeira vez a existência de proteínas ortólogas à FtsH em monocotiledôneas e propuseram uma nova classificação para estas proteases tomando-se como base o perfil filogenético e índice de hidropaticidade do módulo $A A A$ e região C-terminal, bem como predições das localizações 
subcelulares destas proteases. Dessa forma, os autores identificaram que todas as proteínas homólogas à FtsH podiam ser separadas em 5 grandes grupos. Três plastidiais ( $\mathrm{P} 1$ [homólogas à $\mathrm{FtsH}-1$ ], $\mathrm{P} 2$ [homólogas à FtsHVAR2] e P3 [novo grupo]) e duas mitocondriais ( $\mathrm{m} 1 \mathrm{e} \mathrm{m} 2$ ) sem funções definidas.

Assim, como podemos observar, é muito provável que os cloroplastos contenham diferentes isoformas da FtsHs. Contudo, a significância funcional e fisiológica dessa multiplicidade é ainda desconhecida (Adam \& Ostersetzer, 2001). Uma possível explicação poderia ser encontrada no âmbito estrutural. Em bactérias ( $E$. coli) sabe-se que a FtsH é encontrada sob a forma de um oligômero quando associada às membrana (Akiyama et al., 1995; Arlt et al., 1996), isto é, para que exista a proteólise requer-se sua homooligomerização que é promovida pelo seu domínio transmembrana N-terminal (Akiyama \& ito, 2001). Similarmente, vários autores têm mostrado que algumas proteínas da família das AAA formam hetero-oligômeros (Bochtler et al., 2000; Sousa et al., 2000). Como a maioria das FtsHs de plantas apresentam dois domínios transmembrana em suas regiões $\mathrm{N}$-terminais, é possível que elas formem homo e hetero-oligômeros dependendo exclusivamente de eventos tanto fisiológicos quanto metabólicos.

\subsection{Importação de proteínas nos plastídios}

A compartimentalização da célula eucariótica é uma de suas características mais importantes. Durante o processo evolutivo, as reações metabólicas eucarióticas foram sendo compartimentalizadas dentro de organelas envolvidas por membranas que apresentam características únicas, constituindo microambientes sub-celulares.

As células das plantas constituem um interessante sistema no qual a informação genética encontra-se localizada em 3 diferentes compartimentos intracelulares: núcleo, plastídeos e mitocôndrias (Glaser, 1998). No entanto, a capacidade codante dos genomas de mitocôndrias e dos 
plastídeos, é muito limitada, uma vez que seus genes foram perdidos ou transferidos para o núcleo durante a evolução.

Os cloroplastos retém ainda uma capacidade reduzida de codificar 100 a 200 proteínas de um total de aproximadamente 3200 presentes em cianobactérias, seus ancestrais mais prováveis (Bruce, 2000). Assim, cerca de $90 \%$ das proteínas cloroplásticas são codificadas por genes nucleares e sintetizadas nos ribossomos citosólicos sob a forma de grandes precursores (denominadas preproteínas) que apresentam em sua extremidade aminoterminal uma seqüência de direcionamento que é responsável pela importação delas ao interior da organela.

A seqüência de direcionamento para os cloroplastos denominase peptídeo de trânsito e apesar de apresentar um enriquecimento de Ser, Thr e aminoácidos positivos (notadamente Arg), não apresentam uma estrutura secundária característica (von Heijne et al., 1989). O tamanho varia de 20 a 120 resíduos e apresentam basicamente três regiões distintas (Bruce, 2000): uma região amino-terminal não carregada de aproximadamente 10 resíduos, geralmente começando com metionina seguida de alanina e terminando com glicina e prolina. Um domínio central, onde faltam resíduos ácidos mas enriquecido de serina e treonina e uma região carboxi-terminal rica em argininas.

Os plastídeos são organelas extremamente complexas e apresentam seis diferentes sub-compartimentos (membrana externa, membrana interna, espaço intra-membranas, estroma, membrana do tilacóide e lúmen), de forma que um sistema específico de endereçamento foi estabelecido ao longo da evolução.

Uma vez que uma proteína precursora chega à superfície da organela, um processo de reconhecimento altamente específico é iniciado (Jarvis \& Soll, 2001). Três estágios distintos relacionados à disponibilidade de ATP podem ser associados às etapas iniciais do processo de importação. Primeiramente, a ligação da proteína precursora independente de energia (e 
reversível) não requer hidrólise de ATP. Segundo, em concentrações baixas de ATP $(<100 \mu \mathrm{M})$, o precursor insere-se na membrana e entra em contato com proteínas da membrana interna. Há a formação de um intermediário que requer a presença de GTP (este processo é irreversível). Finalmente, em elevadas concentrações de ATP (> $100 \mu \mathrm{M}$ ), o precursor é completamente translocado através da membrana, o peptídeo de trânsito é removido por uma protease estromal e a proteína é montada ou direcionada à outros destinos dentro da organela (Soll, 2002).

Como detalhado na figura 4 , as proteínas precursoras associam-se reversivelmente com as proteínas da membrana externa dos plastídios que formam um complexo da membrana externa conhecido como TOC (translocon at the outer envelope membrane of chloroplasts). Essa associação, provavelmente é realizada por interações proteínas-proteínas e estabilizadas por lipídios de membrana. Uma vez reconhecida, as proteínas precursoras são transferidas para 0 aparato TIC (translocon at the inner envelope membrane of chloroplast). Várias chaperonas presentes em cloroplastos são candidatas a um papel no mecanismo de importação de proteínas. Com70 (Hsp70), encontrada na superfície citoplasmática da membrana externa parece estar envolvida nos estágios iniciais da translocação. Outra Hsp70 têm sido identificada no espaço intermembrana e parece ser responsável por uma atividade de manter a preproteína desdobrada durante o processo. Esta capacidade provê uma força dirigindo o transporte da preproteína através do envelope externo e desse para a membrana interna. Chaperonas moleculares estromais dirigem a importação dentro do estroma, puxando a preproteína para o interior do cloroplasto através de repetidos ciclos de ligação e desassociação. Associa-se ao complexo TIC uma ClpC estromal da família das chaperoninas Hsp100 (Keegstra \& Cline, 1999). Depois da associação das pré-proteínas æ̀ proteínas TOC, as próximas etapas apresentam um alto requerimento energético principalmente de moléculas ATP. 
Após a translocação, ocorre o processamento proteolítico do peptídeo de trânsito por SPPs ("Śtromal Processing Peptidases") (Richter \& Lamppa, 1999).

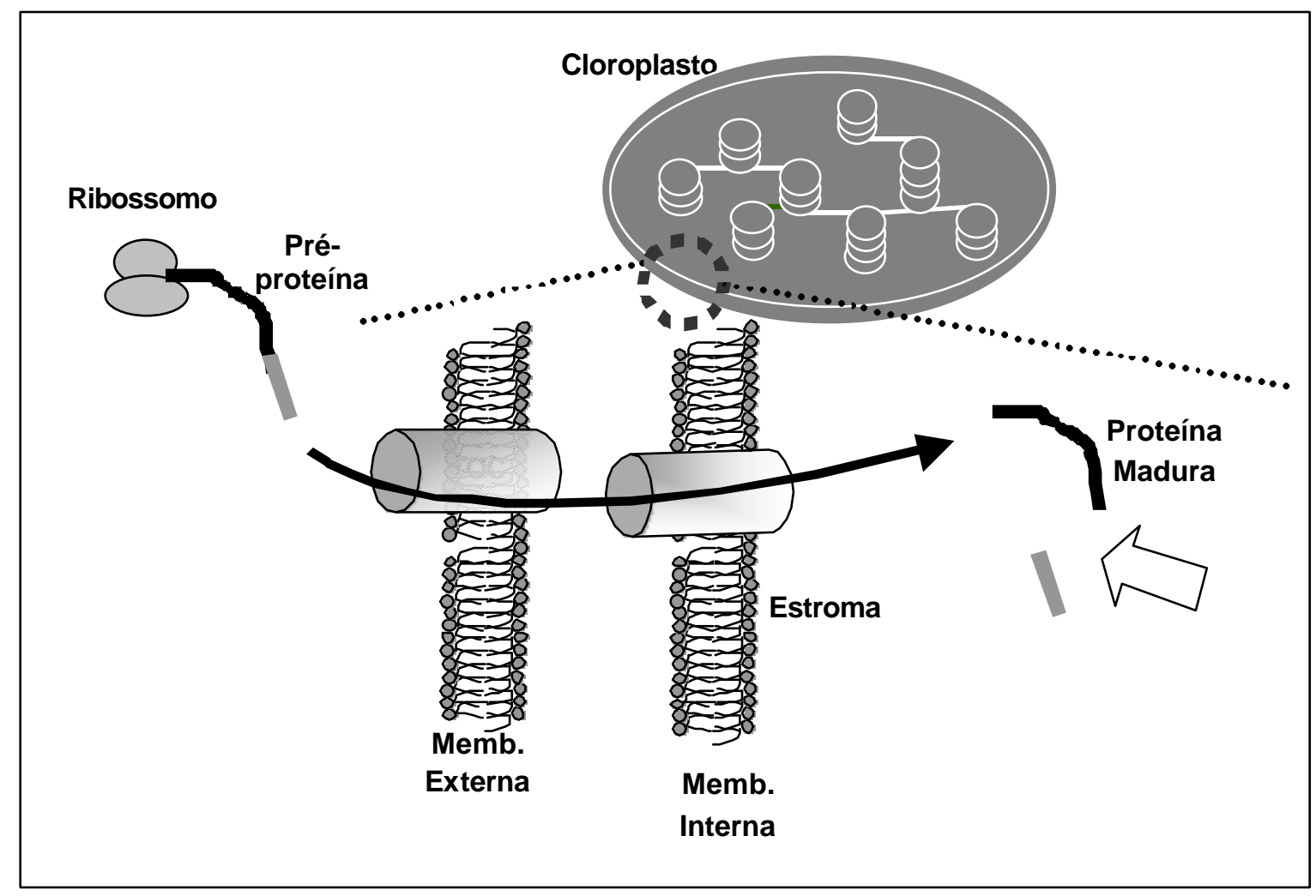

Figura 4 - Esquema mostrando o processo de importação de proteínas precursoras (pré-proteínas) codificadas por ribossomos citosólicos.

Uma grande quantidade de pré-proteínas é importada nos cloroplastos. Para se ter uma idéia, cerca de $2 \times 10^{7}$ moléculas de LHCP são importadas in vivo em 24 horas (Pfisterer et al., 1982). Como cada uma dessas proteínas apresenta um peptídeo de trânsito, que é removido e não fica acumulado no interior dos cloroplastos, acredita-se que haja um mecanismo de 
degradação proteolítica encarregado de eliminá-los seletivamente. Esta atividade é ATP-dependente, sugerindo que os cloroplastos possuem um requerimento de energia especialmente destinado para reciclagem dos peptídeos de trânsito. SSP liga-se ao peptídeos de trânsito, clivando-o a subfragmentos que são reconhecidos e degradados a aminoácidos por uma metalopeptidase (MPP) solúvel, dependente de ATP (Richter \& Lamppa, 1999).

Além do mecanismo geral de direcionamento estromal mencionado acima, existem outros possíveis destinos das pré-proteínas no interior dos cloroplastos. Curiosamente, proteínas destinadas à membrana externa podem inserir-se diretamente, sem hidrólise de ATP, como no caso de TOC34, além de não apresentarem um peptídeo sinal amino-terminal. Um outro caminho é o seguido por TOC75, que contém uma seqüência amino-terminal "bipartite". A primeira parte desta seqüência é clivada no estroma, enquanto que a segunda corresponde a um sinal de paralisação da translocação na membrana externa, removido posteriormente por uma protease não identificada (Keegstra \& Cline, 1999). No mecanismo de translocação para a membrana interna, a proteína é levada até o estroma e depois entregue à sua localização final, ou apresenta um sinal de paralisação da translocação como descrito no caso anterior (Keegstra \& Cline, 1999).

Entretanto, Schatz \& Dobberstein em 1996, cunharam os termos IMPORTAÇÃO e EXPORTAÇÃO para descrever dois diferentes tipos de translocação de proteínas através das membranas celulares (figura 5). De acordo com essa classificação, o processo de importação é aquele que transporta proteínas para o interior de organelas que se apresentam envoltas por membranas (descrito acima). Por outro lado, o processo de exportação transporta proteínas para o espaço extracelular (secreção). Sendo assim, topologicamente o sistema de transporte tais como aqueles que envolvem secreção eucariótica e bacteriana bem como o direcionamento de proteínas para a membrana interna mitocondrial e para as membranas dos tilacóides dos 
cloroplastos podem ser, neste aspecto, todos considerados como vias de exportação (Settles \& Martienssen, 1998).

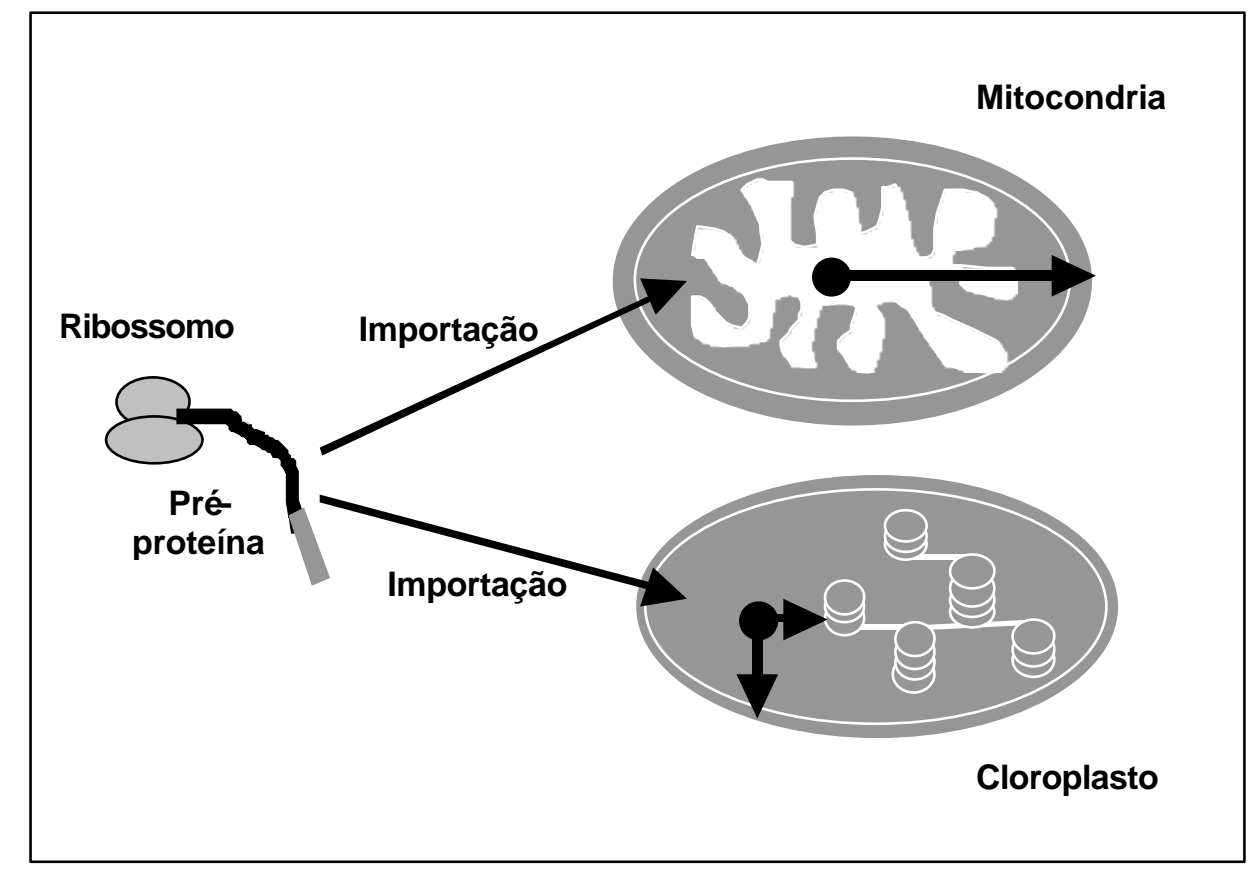

Figura 5 - Esquema mostrando que proteínas que são destinadas aos compartimentos de membranas internos (tilacóides e membrana externa mitocondrial) são translocadas por um processo que envolve 2 passos: a IMPORTAÇÃO e, posteriormente, a EXPORTAÇÂO.

Fonte: Adaptado de Settles \& Martienssen (1998)

Portanto, caso o destino de uma proteína precursora seja as membranas dos tilacóides ou sua região lúmenal, após o processo de importação ter sido finalizado, deve-se dar início o processo de exportação que pode ser realizado por pelo menos 4 mecanismos diferentes (Robinson et al., 
2000): espontaneamente, por uma via dependente de SRP54 (partícula reconhecedora de sinal, semelhante a encontrada no mecanismo de direcionamento para retículo endoplasmático), dependente de um duplo motivo de Arg (conhecido como Tat, por "win arginine translocation") e, finalmente, a que depende da maquinaria SecA (uma proteína homóloga `a proteína secretória SecA bacteriana) (figura 6).

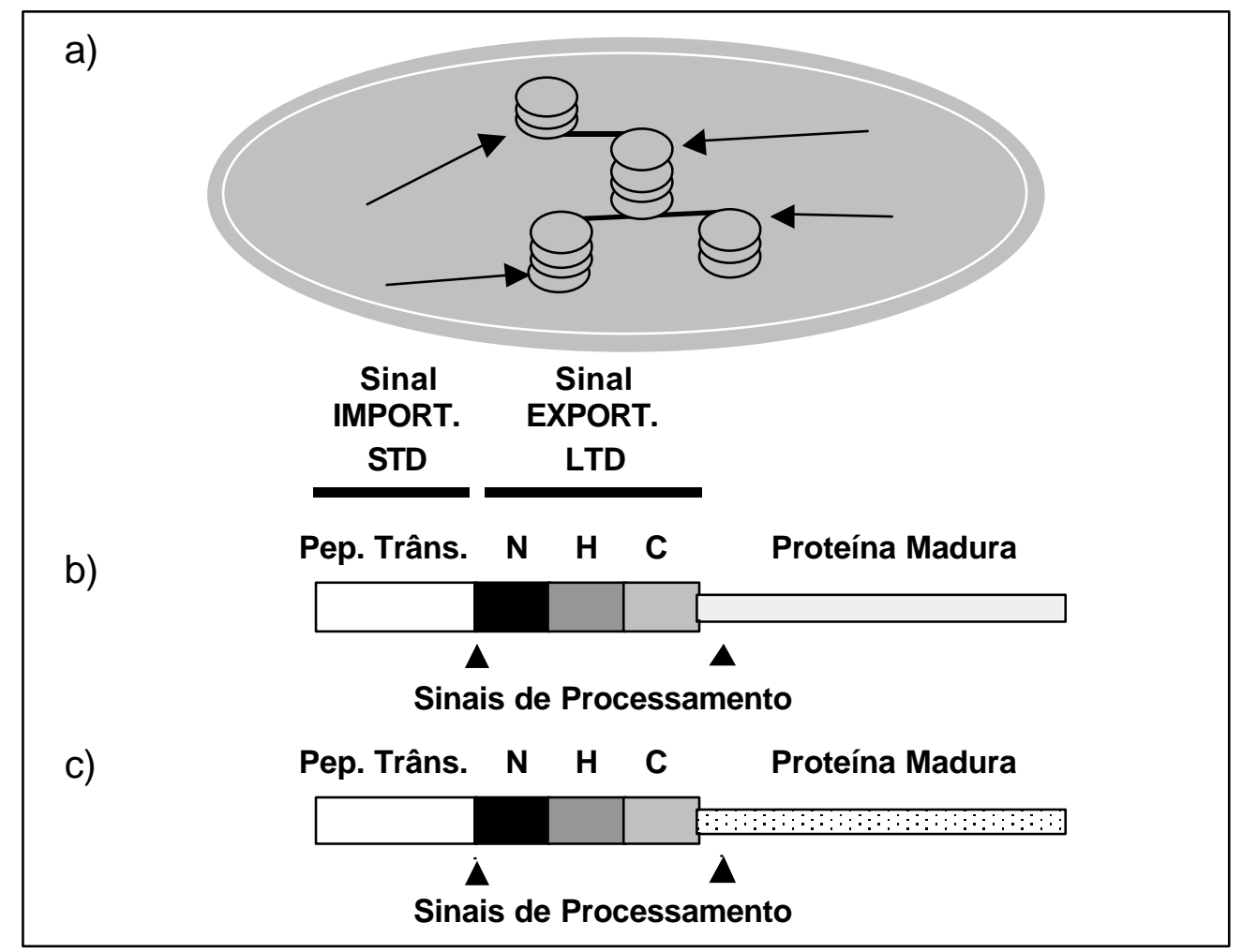

Figura 6 - a) Esquema mostrando as 4 vias de exportação para as membranas dos tilacóides. b) seqüência típica da via Sec de exportação. c) seqüência típica da via Tat (duplo RR). STD=stroma targeting domain. LTD=lumen (thylakoid) targeting domain. 


\subsubsection{Via de inserção dependente de SRP (Signal Recognition Particle)}

O sistema de translocação SRP nos cloroplastos (cpSRP) é utilizado para exportar proteínas aos tilacóides por um mecanismo cotraducional (proteínas traduzidas nos plastídios) bem como via um novo sistema pós-traducional (proteínas LHC-P) (Eichacker \& Henry, 2001). SRP citoplasmáticos contém um componente conservado de RNA associado à uma GTPase de $54 \mathrm{kDa}$, SRP54. Um aspecto central do complexo SRP é a capacidade de ligar-se à regiões hidrofóbicas presentes na extremidade $\mathrm{N}$ terminal de peptídeos nascentes, ou seja, logo após sua saída dos ribossomos. A SRP e seu receptor foram primeiramente caracterizados como sendo componentes essenciais ao transporte co-traducional de proteínas àmembrana do retículo endoplasmático em eucariontes e proteínas de membranas em procariontes (Keenan et al., 2001). Entretanto, a via SRP identificada em tilacóides restringe-se, até o momento, àuma única família gênica que codifica as proteínas LHCP (light harvesting chlorophyll a/b binding proteins), que são componentes do aparato fotossintético (Eichacker \& Henry, 2001).

No processo de direcionamento pós-traducional, a proteína LHCP madura, associa-se à uma forma estromal do complexo SRP formando, aparentemente, um complexo de trânsito solúvel cujo destino é o tilacóide (Li et al., 1995). Um segundo fator solúvel, a FtsY, está também envolvido no mecanismo de inserção que é totalmente dependente da hidrólise de moléculas de GTP. Essa via, parece ser o primeiro exemplo de conservação evolucionária, já que todos os fatores envolvidos nesse processo de exportação são também essenciais na inserção de proteínas na membrana interna de bactérias (Dalbey \& Robinson, 1999). A SRP é uma proteína de ligação à GTP que se liga preferencialmente à regiões de alta hidrofobicidade e junto com FtsY (outra GTPase) transfere a proteína alvo para a maquinaria de translocação (translocom) na membrana bacteriana. Segundo Valent e colaboradores (1998), a FtsY age como uma proteína adaptadora, usando energia derivada da 
hidrólide de GTP para inserir a proteína substrato na membrana. Existem contudo, algumas diferenças entre as vias dependente de SRP bacterianas e cloroplásticas. Por exemplo, enquanto em bactérias a partícula SRP consiste de uma proteína de $48 \mathrm{kDa}$ que está sempre associada com uma molécula de RNA 4,5S, a homóloga cloroplástica (a cpSRP54) é composta de 2 elementos protéicos (heterodímero) de 45 (cpSRP45) e 43kDa (cpSRP43), respectivamente. (Woolhead \& Robinson, 2000). Interessante, é que a cpSRP54 pode ser encontrada em dois "pools" completamente distintos. Em um deles elas sempre estão associadas aos ribossomos (direcionamento cotraducional) e no outro com as proteínas cpSRP43 (direcionamento póstraducional). Este último apresenta importância preponderante no processo de exportação das proteínas LHCPs.

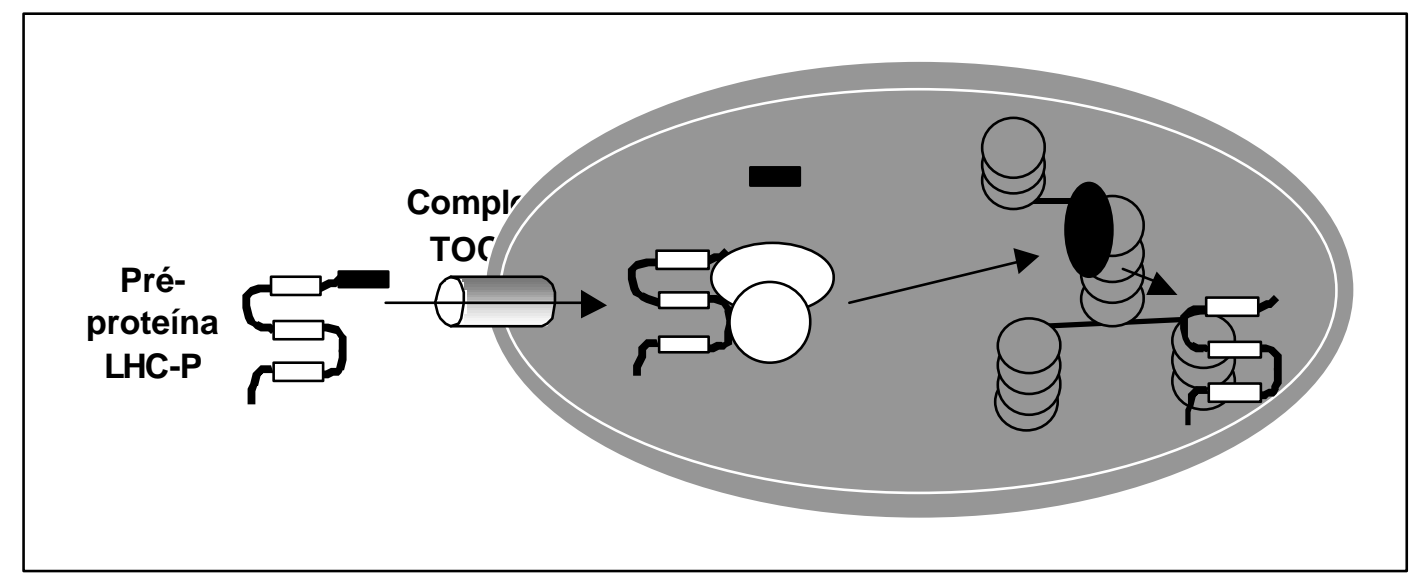

Figura 7 - Via de Translocação da proteína LHC-P (via depende de SRP). Após o processo de importação e clivagem do peptídeo de trânsito, a LHC$P$ é reconhecida pelo complexo cpSRP (composto pelas subunidades cpSRP54 e cpSRP 43) que é responsável, juntamente com o componente FtsY, pela sua exportação até as membranas dos tilacóides.

Fonte: Adaptado de Robinson et al. (2000) 
Em ambos os processos (co e pós traducional) a eficiência da exportação reside na habilidade da partícula SRP54 em reconhecer e associarse a região central hidrofóbica do sinal de trânsito (geralmente na porção madura da proteína) ou no sinal de ancoramento das cadeias peptídicas que estão emergindo dos ribossomos (Eichacker et al., 2001).

Entretanto, com relação ao processo de associação das proteínas æ̀ membranas, ainda é bastante especulativa a hipótese do aparato de translocação Sec (detalhado abaixo) estar envolvido neste processo (figura 7).

\subsubsection{Direcionamento via Sec e dependente de Tat (Twin-arginine translocation)}

Todas as proteínas que são direcionadas por uma das duas vias são sintetizadas no citosol com peptídeos de trânsitos "bipartites" (duplo sinal de direcionamento) onde a primeira parte (STD=stroma targeting domain) dele encarrega-se do direcionamento até o estroma, onde é clivado para expor a segunda parte (a LTD=lumen-targeting domain) que direciona a pré-proteína até o tilacóide. (Robinson et al., 1998). Os sinais de direcionamento para os tilacóides (as LTDs) apresentam 3 motivos que fortemente se assemelham aos encontrados nos peptídeos de trânsito bacterianos (figura 6). Na região aminoterminal do peptídeo, há aminoácidos carregados positivamente, a região central é marcada pela presença de um domínio hidrofóbico e a carboxiterminal por ser polar (Settles \& Martienssen, 1998).

Tanto a via Sec quanto a via tat-dependente transportam proteínas solúveis para a região luminal, porém, elas também podem integrar proteínas nas membranas dos tilacóides (Mori \& Cline, 2001) (figura 8). 


\subsubsection{Via de Translocação Sec}

Em bactérias, o sistema secretório (Sec) requer, geralmente, uma chaperona molecular (SecB) e um complexo translocase (SecYEGDFC)

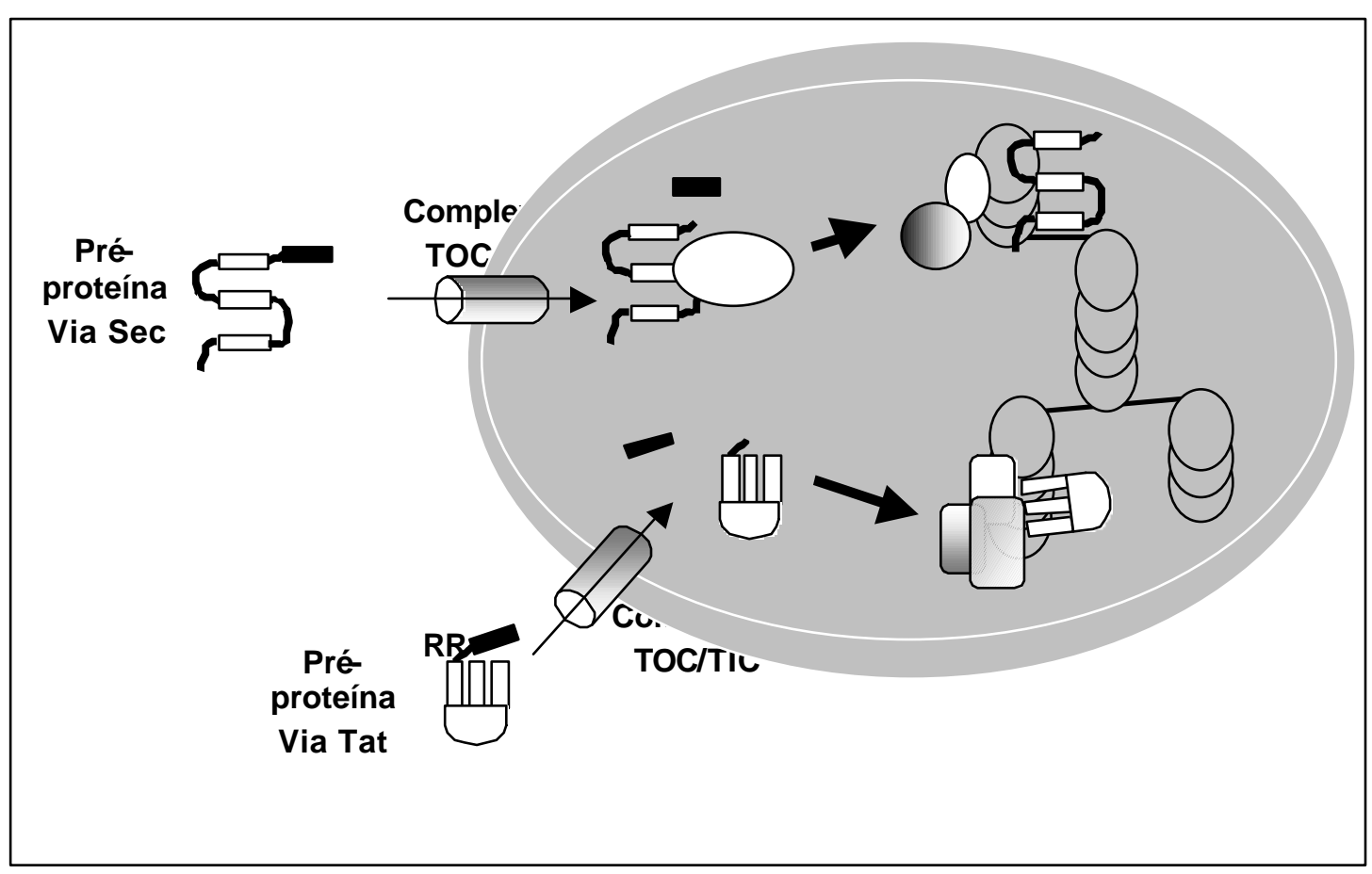

Figura 8 - Esquema mostrando os possíveis componentes do aparato de exportação tanto da via Sec quanto o da via Tat.

Fonte: Adaptado de Robinson et al. (2000)

associado as membranas para que o processo possa ser completado. Assim, $\mathrm{Sec} \mathrm{B}$ associa-se æ̀̀ pré-proteínas retardando a sua montagem. Essa chaperona também é responsável pela apresentação da pré-proteína ao translocom devido sua interação com a proteína SecA que está associada æ̀ membranas. SecA é uma ATPase essencial para o processo de translocação e provavelmente funciona como um motor de translocação "puxando" a proteína 
em processo de exportação através das membranas (Dalbey e Robinson, 1999). O complexo trimérico SecYEG, acredita-se, funciona como um canal de translocação pelo qual a proteína é conduzida. SecD, SecF e SecC também formam um complexo trimérico que possivelmente associa-se com o complexo SecYEG formando assim um complexo hexamérico. As proteínas SecD e SecF são proteínas de membrana que possuem grandes domínios periplasmáticos que auxiliam a manutenção da força próton motora que existe entre os dois lados da membrana e que é responsável por estabilizar SecA e promover a liberação das proteínas exportadas ao espaço periplasmático. Em plantas, segundo Mori \& Cline (2001), proteínas homólogas à SecY, SecE e SecA bacterianas foram recentemente encontradas nas coleções de ESTs de Arabidopsis. Análises têm mostrado que a cpSecE de Arabidopsis é uma proteína integral de tilacóides que forma um complexo de aproximadamente 180 kDa com a proteína SecY cloroplástica. Até o momento, não há evidência experimental das funções de SecE nos tilacóides, porém sua associação com cpSecY antecipa seu provável envolvimento no processo de exportação pela via Sec. Entretanto, nas proteínas SecA de cloroplastos, não encontrourse a sequência de aminoácidos que é responsável pela interação desta proteína com a chaperona SecB. Além disso, até o presente momento não foram mostrados trabalhos identificando a presença de um gene ortólogo à $\mathrm{SecB}$ bacteriana em plantas. Da mesma forma, não encontrou-se no genoma recentemente clonado de Arabidopsis genes ortólogos à SecG, SecF ou SecYajc. Assim, é possível, que no interior dos cloroplastos, o sistema Sec opere com o número mínimo de componentes exigidos por este sistema, apesar de não ser possível descartar a hipótese de que este sistema, no interior desta organela, utiliza outros componentes que ainda necessitam ser desvendados. Summer e colaboradores (2000) propuseram algumas exigências que deveriam ser respeitadas para que um substrato pudesse ser exportado pela via $\mathrm{Sec}$ em cloroplastos. Além do requerimento energético na forma de ATP, seria também necessário um certo gradiente de $\mathrm{pH}$ entre as membranas. Entretanto, $\mathrm{O}$ 
aspecto mais importante era que as pré-proteínas estivessem em uma conformação completamente desmontada (unfolding).

\subsubsection{Via Tat-dependente}

Essa via de exportação de proteínas, foi denominada primeiramente de sistema dependente de $\Delta \mathrm{pH}$ (em cloroplastos) (Mori \& Cline, 2002), ou de sistema de translocação "twin-arginin translocation" =Tat (em bactérias e Arquea), visto que um trabalho recente questionou-se a necessidade de um $\Delta \mathrm{pH}$ no transporte de proteínas em experimentos in vivo (Finazzi et al., 2003). Portanto, neste trabalho esta via será tratada como Tatdependente. $\mathrm{Na}$ verdade, várias características excepcionais distinguem este mecanismo dos demais (figura 8). Na região N-terminal do peptídeo de trânsito das pré-proteínas observa-se um $\mathrm{RR}$ (dupla arginina) que sempre está presente dentro do motivo conservado RRXFLK, onde $X$ representa qualquer aminoácido (Dalbey \& Robinson, 1999). Porém, a mais extraordinária das características é a exigência de que as proteínas precursoras estejam completamente montadas para o sucesso da exportação (Marques et al., 2003). Segundo Mori \& Cline (2002), estudos bioquímicos e genéticos identificaram 3 componentes da maquinaria de exportação Tat no interior de cloroplastos (Hcf106, Tha4 e cpTatC) que são ortólogos bacterianos de TatB, TatA/E e TatC, respectivamente. O complexo cpTatC-Hcf106 é um receptor que apresenta a propriedade de especificamente se associar a proteínas precursoras contendo o motivo conservado RRXFLK. Após esse reconhecimento, a associação deve gerar uma alteração na configuração estrutural do substrato-receptor que é reconhecida por Tha4. Uma vez finalizado o processo de translocação, a Tha4 dissocia-se do complexo receptor. Até recentemente, acreditava-se que esse mecanismo era especificamente utilizado por proteínas solúveis da região lumenal dos tilacóides. Entretanto, em 2000, Summer e colaboradores, mostraram que uma proteína integral de membrana semelhante à FtsH 
bacteriana (a PftF=FtsHP2 ou FtsH-Var2) integrou-se nas membranas dos tilacóides de uma forma Tat-dependente. Esse fato foi comprovado quando cloroplastos isolados de plantas mutantes para o gene hcf106 (faz parte do receptor que reconhece os substratos da via Tat) foram incapazes de integrar a Pftf em seus tilacóides. Entretanto, um resultado interessante mostrado por esses autores foi a não exigência do motivo conservado RR na região aminoterminal. Quando os autores efetuaram uma dupla mutação de RR para KK, a proteína precursora continuou utilizando o mesmo mecanismo de exportação. Esse resultado significativamente expande o número de substratos para a via Tat e sugere uma reavaliação dos elementos que governam seu direcionamento. Interessantemente, uma variação da dupla RR já tinha sido observado anteriormente na proteína cloroplástica Rieske. Ela exibe em sua região amino-terminal, o motivo RK pouco usual, embora seja transportada como uma proteína Tat-dependente (Madueño et al., 1994; Molik et al., 2001). Curiosamente, em bactérias a troca dos aminoácidos RR por $Q Q, R K, K R$ ou KK é suficiente para paralisar o mecanismo de direcionamento. Essa última informação é bastante interessante, pois mostra que a simples substituição do RR por outros aminoácidos não é suficiente para que haja a conversão do peptídeo sinal da via Tat para a via Sec (Sec avoidance ou incompatibilidade entre os sistemas) (Mori \& Cline, 2001).

\subsubsection{Inserção espontânea de proteínas na membrana dos tilacóides}

Algumas proteínas integrais de membrana, de forma bastante surpreendente, não apresentam requerimento por nenhum aparato de direcionamento para que ocorra suas respectivas inserções nas membranas dos tilacóides. Essas proteínas, geralmente com várias regiões hidrofóbicas ("spans" de membranas), também são produzidas com peptídeos de trânsitos "bipartites", semelhante ao casos relatados para as vias $\mathrm{Sec}$ e Tat anteriormente descritas. Em experimentos que envolvem membranas de 
tilacóides isoladas, essas proteínas inserem-se nas membranas dos tilacóides na completa ausência de fatores estromais bem como de nucleotídeos trifosfatados (NTPs). A inserção pode ser observada até mesmo em tilacóides que foram tratados com a protease tripsina que apresenta a capacidade de destruir eventuais complexos protéicos necessários para os eventos de translocação (Woolhead e colaboradores, 2000). Segundo Schleiff \& Klösgen (2001), dois pré-requisitos devem ser preenchidos para que a inserção espontânea possa ocorrer (figura 9). Primeiramente, como um primeiro passo no processo de exportação, a proteína deve ser capaz de se associar com a superfície da membrana. Segundo, a inserção deve ser energicamente favorável a fim de dirigir a translocação do domínio hidrofílico solúvel das proteínas. Sabe-se que estudos bioquímicos envolvendo proteínas modelos com superfícies de lipídios, a associação de um domínio hidrofóbico com a superfície da membrana é um processo altamente favorável. Essa associação imobiliza a proteína na membrana fazendo com que ela perca energia na forma de entropia tanto rotacional e quanto translacional. Dessa forma, para que o processo de exportação espontânea aconteça, a energia ganha durante o processo de associação devido à hidrofobicidade (grande número de regiões hidrofóbicas), deve ser maior do que a perda que ocorre durante o processo de imobilização. 


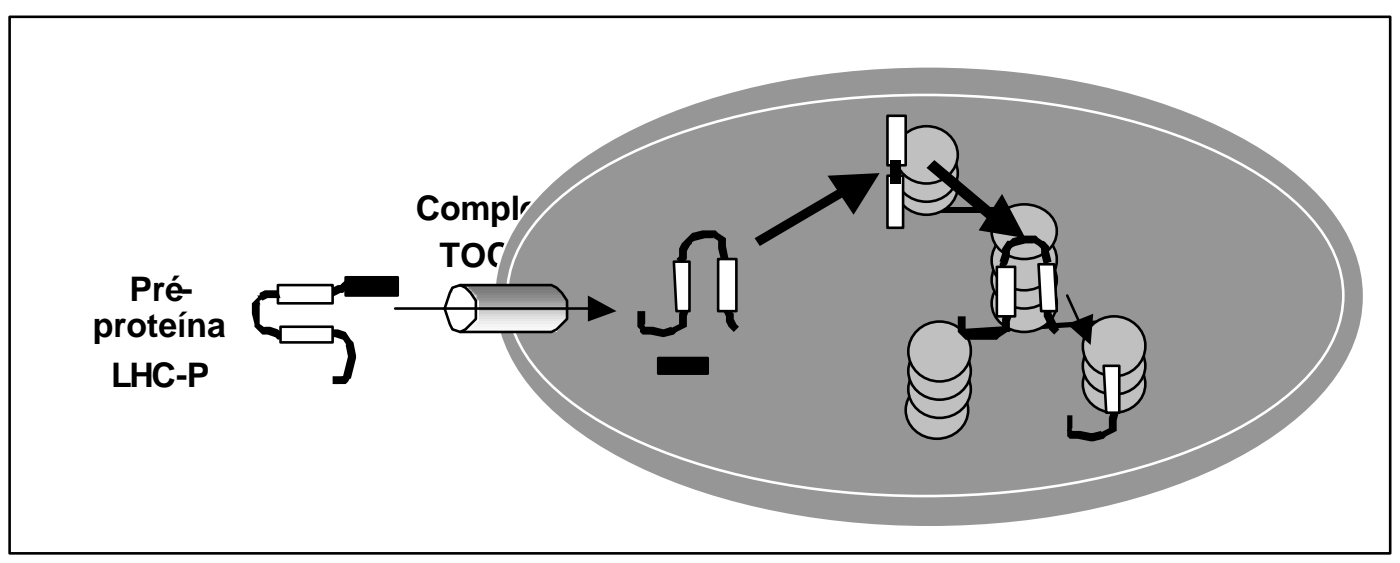

Figura 9 - Esquema mostrando os passos envolvidos no processo de exportação (inserção) das proteínas de membranas dos tilacóides pela via direta (espontânea) ou independente de Sec, Tat ou SRP.

Fonte: Adaptação de Woolhead et al. (2000)

\subsection{Regulação da expressão gênica}

Segundo Rook \& Bevan, (2003), a regulação da expressão gênica representa o alicerce fundamental para o desenvolvimento das plantas em respostas aos estímulos ambientais. As regiões regulatórias dos genes são capazes de detectar estes sinais e responderem ativando ou reprimindo sua expressão. Porém, várias são as formas que a natureza encontrou para regular a expressão gênica. Entretanto, para a maioria dos genes, a regulação transcricional, é de longe, a forma melhor caracterizada.

A análise detalhada de elementos regulatórios nas seqüências de DNA revelou a existência de várias classes de seqüências conservadas no DNA (elementos em cis), que são reconhecidas por fatores transcricionais (proteínas com capacidade de reconhecerem seqüências de nucleotídeos específicas no 
DNA = elementos que agem em cis) (Zhou, 1999). Sendo assim, a especificidade da expressão gênica depende tanto da presença destes elementos em cis na região promotora e/ou enhancers quanto de suas interações com os fatores transcricionais. Obviamente, a própria atividade dos fatores transcricionais pode ser regulada por uma grande variedade de maneiras. O motivo em cis mais característico encontrado na maior parte dos promotores é o TATA BOX que em eucariotos está localizado a uma distância média de $32 \pm 7$ nucleotídeos do sítio de ńicio da transcrição (+1). O motivo TATA-BOX faz parte do que os biólogos moleculares denominam de core promoter. O core promoter, segundo Butler \& Kadonaga (2002), pode ser definido como a região mínima de seqüência de DNA que é suficientemente capaz de dirigir o processo de iniciação da transcrição pela maquinaria da RNA polimerase (expressão basal). Geralmente, o core promoter engloba o sítio de início da transcrição e estende-se ou para esquerda ou para a direita em cerca de 35 nucleotídeos. Dessa forma, em muito exemplos, o core promoter compreende apenas 40 nucleotídeos. Além do TATA-BOX, o core promoter pode englobar o iniciador (Inr), elementos de reconhecimento do fator transcricional TFIIB (BRE) e outros elementos (DPE=dowstream core promoter element) que também podem ser encontrados nessa região (figura 10).

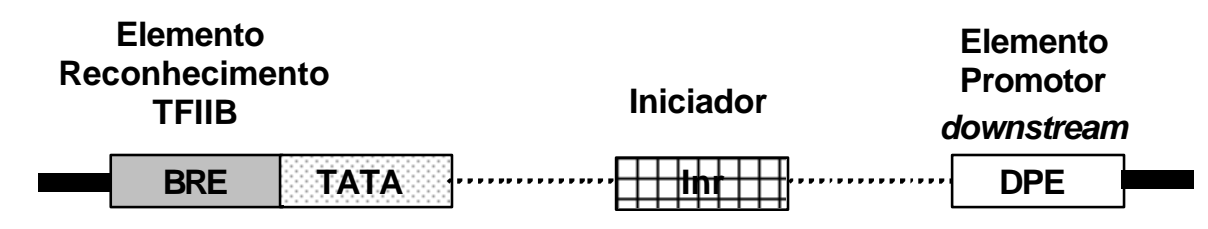

Figura 10 - Esquema representando os elementos do core promoter que podem participar na transcrição pela RNA Polimerase II.

Fonte: Adaptado de Butler \& Kadonaga (2002) 
É importante salientar que esses elementos (motivos) não mostram interdependência, isto é, a presença de todos eles em um mesmo core promoter não é um requerimento absoluto. Por exemplo, não necessariamente todos os core promoters possuem a região TATA-BOX. Sendo assim, fica notório que não existe nenhum elemento em cis que é universal na região promotora. Esse fato, segundo Hehl \& Wingender (2001) é o que justifica a crescente utilização da bioinformática no auxílio de análises e buscas por sequências regulatórias, embora haja a necessidade de experimentação para dar suporte às análises in silico.

De um modo bastante geral, para que exista a expressão basal, além da RNA polimerase II (enzima com muitas subunidades) são necessários fatores auxiliares que fazem parte do denominado Aparato Basal da Transcrição (TFIIA, TFIIB, TFII D, TFIIE, TFIIF e TFIIH). Nos core promoters dependentes da região TATA-BOX, o processo transcricional inicia-se com 0 fator TFIID que é uma proteína multimérica composta pelas seguintes subunidades: a TBP (para TATAbox-binding protein) e cerca de 13 proteínas TAFs (para TBP-associated factors). Após a associação do fator TFIID (reconhecimento da região TATA) há o recrutamento dos outros fatores do aparato basal que juntamente com a RNA Pol II, formam o Complexo de PréIniciação (PIC) dando inicio ao processo de iniciação da transcrição na região +1 .

Além do core promoter, outras seqüências de DNA agindo em cis que regulam a transcrição pela RNA polimerase II, incluem o promotor proximal, enhancers e silenciadores (West et al., 2002). O promotor proximal é a região que engloba os nucleotídeos reunidos nas vizinhanças do sítio de inicio da transcrição (de +250 a -250). Os enhancers e os silenciadores, por sua vez, são sequências (motivos) que agem ativando ou reprimindo a expressão gênica e podem localizar-se à muitos milhares de nucleotídeos do sítio de início da transcrição. Segundo Butler \& Kadonaga (2002), é justamente da interação existente entre os fatores trancricionais que reconhecem os motivos 
pertencentes àregião enhancer ou promotor principal com os do core promoter que faz com que se estabeleça tanto a regulação espacial quanto a temporal da expressão gênica.

Sendo assim, o isolamento de seqüências promotoras e enhancers torna-se uma fato bastante justificado de ser realizado para tentar compreender os aspectos que regem a regulação de uma determinada seqüência gênica. 


\section{MATERIAL E MÉTODOS}

\subsection{Clonagem do cDNA da FtsH-p1 de tomate e localização subcelular}

\subsubsection{Construções gênicas}

Procedimentos padrões foram utilizados na realização das construções gênicas (Sambrook et al., 1989).

\subsubsection{Espécie vegetal}

Todos os procedimentos referentes as etapas de clonagem do cDNA da FtsH-p1 foram realizados com a espécie Lycopersicon esculentum (var. micro-tom). As etapas envolvendo expressão estável e transiente foram realizadas com Nicotiana tabacum (var SR1) e Allium cepa, respectivamente.

\subsubsection{Análise das sequências ortólogas à FtsH-p1 em plantas superiores depositadas em Banco de Dados}

Para a clonagem do cDNA da FtsH-p1 de tomate, uma busca por seqüências similares em plantas superiores depositadas em bancos de dados foi realizada com 0 auxílio do programa "BLAST 2.0 (http://www.ncbi.nlm.nih.gov). O resultado indicou a presença de 6 proteínas sendo nitidamente divididas em duas famílias diferentes (FtsH-p1 e FtsH-p2). Baseando-se nas seqüências provenientes dos acessos AB017480 (FtsH-p1 de 
Nicotiana tabacum) e X90472 (FtsH-p1 de Capisicum annuum) foram desenhados dois oligonucleotídeos degenerados (TOM1 5'

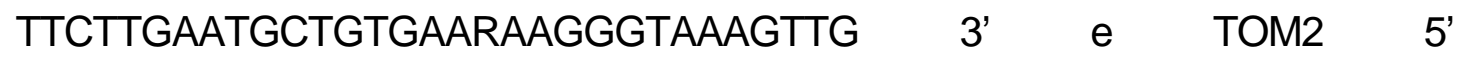
TCTTTCTTCGCTRGGGGCAAAGAAGGT 3') que flanqueavam a região de maior homologia destas sequências.

\subsubsection{Aplificação do fragmento correspondente à região central do gene ortólogo àFtsH-p1 de tomate}

\subsubsection{Preparação do material e soluções para o isolamento de RNA total}

O material e soluções, com exceção de Tris- $\mathrm{HCl}$ e solventes orgânicos utilizados para isolamento de RNA total, foram tratados com dietil pirocarbonato (DEPC 0,1\%) para completa eliminação das RNAses exógenas, conforme Sambrook et al. (1989).

\subsubsection{Extração de RNA de frutos e folhas de tomate}

\subsection{Homogenização}

Amostras $(100 \mathrm{mg})$ de frutos maduros ou folhas de tomate ( $L$. esculentum) e pimentão (C. annuum) foram macerados em almofariz com $1 \mathrm{~mL}$ de $\operatorname{Trizol}^{\circledR}$, e o extrato resultante transferido para tubo tipo Eppendorf de 1,5 mL. $O$ homogenizado foi incubado por 5 minutos à temperatura ambiente, e para reduzir compostos indesejáveis como por exemplo polissacarídeos, lipídeos e DNA, a solução foi centrifugada a $12.000 \times$ (microcentrífuga) por 15 minutos, a $4^{\circ} \mathrm{C}$, e o sobrenadante recolhido em um novo tubo. 


\subsection{Fase de preparação}

Ao tubo Eppendorf, foi adicionado $0,2 \mathrm{~mL}$ de clorofórmio (puro) sob agitação intensa por 15 segundos. Após este procedimento, o tubo foi incubado por 3 minutos àtemperatura ambiente e, posteriormente, centrifugado a $12.000 x g$ (microcentrífuga de mesa) por 15 minutos a $4^{\circ} \mathrm{C}$. (A mistura separase em uma fase vermelha no fundo do tubo - fase fenol/clorofórmio, uma interfase e uma fase aquosa, contendo o RNA, com volume de aproximadamente $60 \%$ do volume de Trizol utilizado na homogeneização).

\subsection{Precipitação do RNA}

Transferiu-se a fase aquosa para um novo tubo Eppendorf $\mathrm{e}$ precipitou-se o RNA adicionando-se $0,5 \mathrm{~mL}$ de isopropanol por $1 \mathrm{~mL}$ de Trizol utilizado no início. (Para melhorar a qualidade do RNA e diminuir a contaminação com DNA, metade da solução de isopropanol foi substituída por 0,250 mL de citrato de sódio 0,8M com cloreto de sódio 1,2M preparado com água tratada com DEPC 0,01\%). As amostras foram incubadas à temperatura ambiente por 10 minutos e posteriormente centrifugadas a $12.000 x g$ por 10 minutos, a $4^{\circ} \mathrm{C}$, sendo o sobrenadante removido. O RNA precipitado, normalmente invisível antes da centrifugação, formou um "pellet" gelatinoso no fundo do tubo.

\subsection{Lavagem do RNA}

O "pellet" foi lavado uma vez com $1 \mathrm{~mL}$ de etanol 75\% (preparado com água tratada com DEPC 0,01\%) e a amostra resultante misturada no "vortex" e centrifugada a $7.500 x g$ por 5 minutos, a $4{ }^{\circ} \mathrm{C}$. O sobrenadante foi descartado. 


\subsection{Ressuspensão do RNA}

Secou-se o "pellet" de RNA a temperatura ambiente por 5-10 minutos. Posteriormente, ele foi ressuspendido em $20-80 \mu \mathrm{L}$ de água livre de RNAse (tratada com DEPC 0,01\%) passando a solução algumas vezes através da ponteira da pipeta. Essa amostra foi incubada por 10 minutos, a $55-60^{\circ} \mathrm{C}$. Para verificar a presença de RNA, leituras espectrofotométricas da solução obtida foram tomadas à $260-280 \mathrm{~nm}$. Amostras de RNA parcialmente dissolvidas tem uma razão $\mathrm{A}_{260} / \mathrm{A}_{280}<1,6$.

\subsubsection{Eletroforese de RNA em gel desnaturante}

A separação eletroforética das amostras de RNA total foi conduzida em gel de agarose em condições desnaturantes e específicas para RNA seguindo o protocolo descrito por Sambrook e colaboradores (1989) com algumas modificações. 1,2g de agarose foi fundida junto com um tampão FA (pH 7,0) 10X concentrado, composto de $200 \mathrm{mM}$ de ácido 3-[Nmorpholino]propanesulfonic (MOPS), $50 \mathrm{mM}$ de acetato de sódio e $10 \mathrm{mM}$ de EDTA. Quando a agarose se encontrava em aproximadamente $65^{\circ} \mathrm{C}$, adicionou-se 1,8 $\mathrm{mL}$ de formaldeído $37 \%$ (12,3M) e $1 \mu \mathrm{L}$ de brometo de etídeo (10 mg/mL). Esta solução foi vertida em um suporte sólido e após sua polimerização, foi equilibrada por 30 minutos com tampão de corrida FA (1X) composto de $100 \mathrm{~mL}$ de tampão $\mathrm{FA}$ (10x), $20 \mathrm{~mL}$ de formaldeído $37 \%$ (=12,3M) e $880 \mathrm{~mL}$ de água livre de RNAse. 4 volumes de amostra de RNA foram misturados à 1 volume de uma solução estoque de tampão de carregamento do RNA 5X concentrada, composta de $16 \mu \mathrm{L}$ de solução de azul de bromofenol saturada, $80 \mu \mathrm{L}$ de EDTA $500 \mathrm{mM}(\mathrm{pH}$ 8,0), $720 \mu \mathrm{L}$ de formaldeído 37\% (=12,3M), $2 \mathrm{~mL}$ de glicerol 100\%, $3084 \mu \mathrm{L}$ de formamida, $4 \mathrm{~mL}$ de tampão $\mathrm{FA}$ (10X) e água livre de RNase até um volume final de $10 \mathrm{~mL}$. Antes do gel ser 
carregado, as amostras de RNA juntamente com o tampão de carregamento foram aquecidos por 5 minutos a $65^{\circ} \mathrm{C}$.

\subsubsection{Síntese da primeira fita de cDNA usando o KIT SUPERSCRIPT II PRE- AMPLFICATION SYSTEM ${ }^{\circledR}$ para RT-PCR (Gibco BRL)}

Em um tubo Eppendorff estéril $(0,5 \mathrm{~mL})$, foi adicionado $1 \mu \mathrm{L}$ de oligo(dT), $2 \mu \mathrm{L}(5 \mu \mathrm{g})$ de RNA obtido na extração anterior e $12 \mu \mathrm{L}$ de água tratada com DEPC $0,01 \%$. A mistura foi aquecida a $70^{\circ} \mathrm{C}$ por 10 minutos e colocada no gelo por 1 minuto. Adicionaram-se $4 \mu \mathrm{L}$ de tampão First Strand (5X), $2 \mu \mathrm{L}$ de DTT $(0,1 \mathrm{M})$ e $1 \mu \mathrm{L}$ de mix dNTP (10mM). Os componentes foram misturados e incubados a $42^{\circ} \mathrm{C}$ por 2 minutos após os quais foi adicionado $1 \mu \mathrm{L}$ (200 unidades) de SuperScript II (Transcriptase Reversa). O tubo foi incubado a $42^{\circ} \mathrm{C}$ por 50 minutos e a reação inativada por aquecimento a $70^{\circ} \mathrm{C}$ por 15 minutos. Ao tubo foi adicionado $1 \mu \mathrm{L}$ (2 unidades) de RNAse $\mathrm{H}$ de E. coli e o mesmo incubado a $37^{\circ} \mathrm{C}$ por 20 minutos. O cDNA foi então usado como molde para amplificação por PCR.

\subsubsection{Reação de PCR para amplificação da seqüência específica correspondente àregião central do gene FtsH-p1}

Para amplificar o fragmento específico, foram adicionados os seguintes componentes em um tubo Eppendorf:

- $10 \mu \mathrm{L}$ de tampão (10X) para PCR (200mM de TrisHCl $(\mathrm{pH} 8,4), 500 \mathrm{mM} \mathrm{KCl})$

- $3 \mu \mathrm{L}$ de $\mathrm{MgCb}(50 \mathrm{mM})$

- $2 \mu \mathrm{L}$ de dNTP mix (10mM)

- $1 \mu \mathrm{L}$ de oligonucleotídeo degenerado TOM 1 (30 pmol)

- $1 \mu \mathrm{L}$ de oligonucletídeo degenerado TOM2 (30 pmol)

- $\quad 1 \mu \mathrm{L}$ de Taq DNA polimerase (5 unidades $/ \mu \mathrm{L}$ )

- $\quad 2 \mu \mathrm{L}$ de cDNA (da reação anterior)

- $80 \mu \mathrm{L}$ de água estéril 


\section{Programa de PCR:}

- $94^{\circ} \mathrm{C}$ por 3 minutos

- $\quad 94^{\circ} \mathrm{C}$ por 1 minuto

- $55^{\circ} \mathrm{C}$ por 1 minuto

- $\quad 72^{\circ} \mathrm{C}$ por 90 segundos

- $72^{\circ} \mathrm{C}$ por 3 minutos

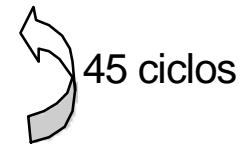

\subsubsection{Extração do fragmento desejado (região central) do gel de agarose}

As amostras obtidas pela reação de PCR foram aplicadas em gel de agarose 1\%. Um fragmento de 1272 pares de bases foi amplificado e, posteriormente, purificado do gel de agarose utilizando-se o Kit Qiaex $\|^{\circledR}$ da Qiagen.

\subsubsection{Clonagem do fagmento proveniente da reação de PCR (1272 pb) utilizando o Kit Sure Clone $^{\mathrm{TM}}$ Ligation da Amersham Pharmacia Biotech}

Muitas polimerases termoestáveis possuem uma atividade de polimerização independente de "template", adicionando um único dATP (adenina) na extremidade 3' do fragmento amplificado. Essa atividade pode interferir na subsequente clonagem dos fragmentos gerados por PCR. Neste Kit, o produto de PCR é então preparado para ligação utilizando-se a atividade exonucleásica 3'-5' do fragmento Klenow da DNA polimerase I para remover a extremidade 3'-protuberante composta de uma única base adenina. Na mesma reação, os produtos da reação de PCR são também fosforilados na extremidade 5', devido a presença da enzima $T_{4}$ polinucleotídeo quinase. Esse fragmento é então ligado a um vetor pUC 18 previamente digerido com Sma I e desfosforilado, também fornecido pelo Kit. 


\subsubsection{Reação Blunting/Kinasing}

Segundo recomendações do fabricante, a quantidade de DNA necessária para a reação Bunting/Kinasing, varia conforme o número de pares de bases do fragmento. Dessa forma, em tubos do tipo Eppendorf, foram adicionados cerca de 200 a $300 \mathrm{ng}$ do fragmento amplificado da região central (1272 pares de bases). Adicionou-se $1 \mu \mathrm{L}$ de fragmento Klenow, $2 \mu \mathrm{L}$ de tampão Blunting/kinasing (10X), $1 \mu \mathrm{L}$ de $\mathrm{T}_{4}$ polinucleotídeo kinase e água estéril até um volume final de $20 \mu \mathrm{L}$. Essa mistura foi incubada por 30 minutos a $37^{\circ} \mathrm{C}$. Posteriormente, adicionaram-se $20 \mu \mathrm{L}$ de solução fenol/clorofórmio, a solução foi agitada no "vortex" e, posteriormente, centrifugada por 1 minuto a 13000xg (microcentrifuga de mesa). A camada superior (aquosa) foi coletada e vertida em uma coluna de purificação MicroSpin contendo Sephacryll S-200 (fornecida pelo kit).

\subsubsection{Ligação}

Para a reação de ligação, em um tubo do tipo Eppendorf, foram adicionados os seguintes componentes: $2 \mu \mathrm{L}$ do efluente da coluna, $1 \mu \mathrm{L}$ do vetor pUC18 digerido com Sma I e desforilado (50 ng), $10 \mu \mathrm{L}$ de tampão de ligação (2X), $1 \mu \mathrm{L}$ de solução DTT (200 mM), $1 \mu \mathrm{L}$ de $\mathrm{T}_{4}$ DNA ligase e $5 \mu \mathrm{L}$ de água estéril. Essa reação foi incubada por 2 horas a $16^{\circ} \mathrm{C}$. Essa reação gerou 0 vetor pUC18-FtsH-p1 (1272 pb).

\subsubsection{Preparo de células competentes de E. coli (JM 109) para transformação}

A bactéria $E$. coli (JM 109), estocada à $-80^{\circ} \mathrm{C}$, foi inoculada em 2 $\mathrm{mL}$ de $\mathrm{LB}$ e incubada por 15 horas a $37^{\circ} \mathrm{C}$. Após este período, $500 \mu \mathrm{L}$ dessa 
suspensão foram colocados em $50 \mathrm{~mL}$ de meio LB estéril e mantidos sob agitação (180 rpm) a $37^{\circ} \mathrm{C}$ por aproximadamente 2 horas onde a absorbância $\left(D_{600}\right)$ não ultrapassou os valores 0,3-0,4. Nesse ponto, a cultura foi transferida para um tubo SS-34 e centrifugada a $6000 \mathrm{rpm}$ (rotor SLT 50 da Sorvall) por 2 minutos a $4^{\circ} \mathrm{C}$. O sobrenadante foi descartado e o "pellet" ressuspendido em $40 \mathrm{~mL}$ de solução $\mathrm{CaCl}_{2}(50 \mathrm{mM})$ e mantido no gelo por cerca de 30 minutos. Após este período, o tubo foi novamente centrifugado durante 2 minutos, a $4^{\circ} \mathrm{C}(6000 \mathrm{rpm}$ - rotor SLT 50 da Sorvall), o sobrenadante descartado e o "pellet" ressuspendido em 2,5 mL de $\mathrm{CaCb}(50 \mathrm{mM})$.

\subsection{Meios de cultura}

Para crescimento de E. coli e Agrobacterium tumefaciens foi utilizado o meio de cultura Luria-Bertani (LB), composto de $1 \%(\mathrm{p} / \mathrm{v})$ de bactotriptona, $0,5 \%(\mathrm{p} / \mathrm{v})$ de extrato de levedo, $1 \%(\mathrm{p} / \mathrm{v})$ de $\mathrm{NaCl}, \mathrm{pH} 7,5$, acrescido de $0,01 \%(\mathrm{p} / \mathrm{v})$ de canamicina (para E. coll) e $0,01 \%(\mathrm{p} / \mathrm{v})$ de rifampicina (para A. tumefaciens). Quando necessário, $0,8 \%$ de bacto-agar foi adicionado ao meio.

Para a transformação e crescimento das plantas, o meio MS de Murashige \& Skoog (1962) foi adquirido da SIGMA e suplementado com 0,8\% $(\mathrm{p} / \mathrm{v})$ de ágar. Foram também utilizados os meios MSACKC que consiste no meio básico MS acrescido de $2 \times 10^{-5} \%(\mathrm{p} / \mathrm{v})$ de ácido indol acético, $2 \times 10^{-5} \%(\mathrm{p} / \mathrm{v})$ de 6 -BAP, $0,04 \%(\mathrm{p} / \mathrm{v})$ de carbenicilina, $0,01 \%(\mathrm{p} / \mathrm{v})$ de canamicina e $0,04 \%$ $(\mathrm{p} / \mathrm{v})$ de cefotaxime. O meio MSAKC que é o mesmo descrito anteriormente sem a adição de 6-BAP e carbenicilina.

\subsubsection{Transformação de E. coli (JM 109)}

Para a transformação, foram utilizados $200 \mu \mathrm{L}$ de células competentes e $5 \mu \mathrm{L}$ da ligação. As células foram incubadas no gelo por 30 
minutos, sendo em seguida, submetidas à um choque térmico de $42^{\circ} \mathrm{C}$, por 1 minuto e novamente deixadas no gelo. Adicionourse $1,0 \mathrm{~mL}$ de meio $\mathrm{LB}$ e manteve-se a suspensão celular por 1 hora a $37^{\circ} \mathrm{C}$. Em seguida, a amostra foi centrifugada a $13000 \mathrm{rpm}$ (microcentrífuga de mesa) por 1 minuto e foram descartados aproximadamente $900 \mu \mathrm{L}$ do sobrenadante. As células foram colocadas em suspensão com o resíduo do meio líquido que permaneceu no tubo. As células foram plaqueadas em placa de Petri contendo meio de cultura LB com o antibiótico ampicilina (100mg/L), X-gal (1 mg/placa) e IPTG $100 \mathrm{mM}$ (15 $\mu \mathrm{L} /$ placa). As placas foram incubadas a $37^{\circ} \mathrm{C}$, por 20 horas.

\subsubsection{Avaliação da transformação ("screening" por PCR diretamente nas bactérias)}

As colônias que cresceram no meio seletivo e perderam a capacidade de quebrar o substrato X-gal (colônias brancas) devido a introdução do inserto no sítio de multiclonagem, foram repicadas em outra placa ("Master") e procedeu-se uma reação de PCR utilizando-se diretamente as bactérias, para identificar as colônias que receberam o vetor pUC18-FtsH-p1(1272pb). Na reação de PCR para "screening" das colônias, uma pequena quantidade de bactéria foi inoculada em $25 \mu \mathrm{L}$ de água e lisadas a $94^{\circ} \mathrm{C}$. Adicionou-se em cada reação, uma mistura contendo $15,2 \mu \mathrm{L}$ de água estéril, $5 \mu \mathrm{L}$ de tampão para PCR (10X), $3 \mu \mathrm{L}$ de $\mathrm{MgCl}_{2}$ (25mM), 0,5 $\mu \mathrm{L}$ de dNTP mix (2,5 mM), 0,5 $\mu \mathrm{L}$ do iniciador universal, $0,5 \mu \mathrm{L}$ do iniciador reverso e $0,3 \mu \mathrm{L}$ de Taq DNA polimerase $(5 \mathrm{u} / \mu \mathrm{L})$. Foram conduzidas 45 repetições do ciclo de amplificação composto de:

- $\quad 94^{\circ} \mathrm{C}$ por 2 minutos

- $\quad 94^{\circ} \mathrm{C}$ por 1 minuto

- $\quad 55^{\circ} \mathrm{C}$ por 1 minuto

- $\quad 72^{\circ} \mathrm{C}$ por 2 minutos

- $\quad 72^{\circ} \mathrm{C}$ por 3 minutos

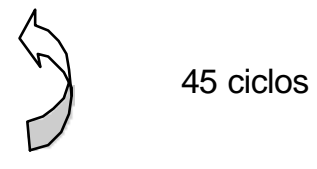




\subsubsection{4 "Mini-prep" para extração dos plasmídios pUC18 FtsH-p1 (1272pb) das colônias selecionadas}

Para extração dos plasmídios das colônias selecionadas, utilizout se o método da lise alcalina (Sambrook et al., 1989).

\subsubsection{Sequenciamento do DNA dos clones obtidos}

Alguns clones positivos foram enviados para sequenciamento (sequenciador de DNA ABI PRISM 377) no laboratório de Entomologia, Fitopatologia e Zoologia Agrícola da ESALQ, sob a coordenação do Prof. Luiz Eduardo Aranha Camargo.

A reação de sequenciamento, foi realizada usando-se os procedimentos descritos no manual do kit $A B I$ PRISM $^{\otimes}$ Big Dye ${ }^{T M}$ TERMINATOR CYCLE SEQUENCING READY REACTION KITS. Seguindo este protocolo, em tubos de 0,2 $\mathrm{mL}$ foram adicionados $2 \mu \mathrm{L}$ de mix Big Dye (que contém dNTP, terminadores (ddNTPs) associados à substâncias fluorescentes e AmpliTaq DNA polimerase, FS), 3 picomoles dos iniciadores (universal ou reverso), 10,5 $\mu \mathrm{L}$ de água estéril, $6 \mu \mathrm{L}$ de tampão Tris- $\mathrm{HCl} p H 9,0$ contendo cloreto de magnésio e 0,5 $\mu \mathrm{L}$ de DNA plasmidial (200-500 ng). A seguinte reação de PCR foi utilizada:

- $96^{\circ} \mathrm{C}$ por 2 minutos

- $96^{\circ} \mathrm{C}$ por 20 segundos

- $50^{\circ} \mathrm{C}$ por 10 segundos

- $60^{\circ} \mathrm{C}$ por 4 minutos

- $\quad 72^{\circ} \mathrm{C}$ por 7 minutos 25 ciclos

Após a reação de amplificação, a amostra foi transferida para tubos do tipo Eppendorf de 0,65 mL e adicionou-se uma solução contendo 20 $\mu \mathrm{L}$ de água estéril $+60 \mu \mathrm{L}$ de isopropanol. Essa mistura foi deixada à temperatura ambiente por 15 minutos e centrifugada em uma microcentrifuga 
de mesa (velocidade máxima) por 20 minutos. 0 sobrenadante foi cuidadosamente descartado e o "pellet" lavado com $250 \mu \mathrm{L}$ de etanol $70 \%$ (preparado na hora). Centrifugourse por mais 15 minutos sob as mesmas condições anteriores e o sobrenadante novamente descartado. Os tubos, com as tampas abertas, foram colocados por 1 minuto em um termociclador previamente aquecido a $90^{\circ} \mathrm{C}$ para a completa evaporação da água das amostras.

No laboratório onde foi realizado o sequenciamento, as amostras foram ressuspendidas em $4 \mu \mathrm{L}$ de tampão contendo 5 partes de formamida e 1 parte de tampão de carregamento $(0,25 \%$ azul de bromofenol, $0,25 \%$ xileno cianol e $40 \%$ sacarose), o DNA foi desnaturado à $98^{\circ} \mathrm{C}$ por 2 minutos e $1 \mu \mathrm{L}$ de cada amostra foi aplicado no gel por Daniela Truffi.

As colônias com as sequências desejadas foram repicadas e estocadas em glicerol a $-80^{\circ} \mathrm{C}$.

\subsubsection{Subclonagem do fragmento de $1272 \mathrm{pb}$ correspondente à região central do gene FtsH-p1}

Para a eapa de subclonagem, $5 \mu \mathrm{g}$ do plasmídio pUC18 FtsHp1(1272pb) foram primeiramente digeridos com as enzimas de restrição EcoRl e BamHI para a liberação do fragmento de 1272 pb, que foi purificado do gel de agarose, conforme descrito anteriormente. Aproximadamente $2 \mu \mathrm{g}$ desse fragmento foram digeridos com a enzima Sau3Al que deveria reconhecer 4 sítios de restrição dentro desta seqüência e produzir 5 fragmentos correspondentes a 104, 134, 457, 486 e 503 pares de bases, respectivamente. $O$ produto da reação de digestão foi colocado em gel de agarose e os fragmentos foram purificados. É importante salientar, que alguns destes fragmentos apresentam extremidades Sau3A1 (compatível com o sítio BamHI) e outros Sau3A1 e EcoRl. 
Após esta etapa, os fragmentos foram clonados no vetor pBluescript SK(-) (Stratagene) previamente digerido somente com BamHI ou então duplamente digeridos com BamHI e EcoRI. Procedimentos padrões estabelecidos por Sambrook e colaboradores, (1989) foram utilizados nas manipulações desenvolvidas durante as etapas de clonagem. Novamente, as colônias obtidas de todos os 5 eventos de transformação foram analisadas via sequenciamento conforme metodologia já descrita anteriormente.

\subsubsection{Obtenção da extremidade 5' do gene FtsH-p1 à partir do fragmento amplificado (1272 pb), utilizando o kit 5'-RACE (RAPID AMPLIFICATION of cDNA ENDS) da Gibco-BRL}

\subsubsection{Isolamento do RNA total}

A metodologia utilizada na extração do RNA total foi detalhada anteriormente no item 3.1.4.2.

\subsubsection{Síntese da primeira fita do cDNA}

Para a síntese da primeira fita de cDNA foi necessário desenhar um oligonucleotídeo sequência específico (GSP1TOM = TTCACCTTCAGAAACTGATA 3') cuja seqüência foi obtida do fragmento amplificado e sequenciado anteriormente (fragmento de 1272 pares de bases)

Em um tubo do tipo Eppendorf $(0,65 \mathrm{~mL})$ foram adicionados $2 \mu \mathrm{L}$ do iniciador GSP1-TOM (2,5 picomoles), $5 \mu \mathrm{L}$ de amostra de RNA total (aproximadamente $5 \mu \mathrm{g}$ ) e $8,5 \mu \mathrm{L}$ de água estéril tratada com DEPC 0,01\%. A mistura foi então incubada por 10 minutos a $70^{\circ} \mathrm{C}$ para desnaturar o RNA. $\mathrm{O}$ tubo foi colocado no gelo por 1 minuto onde, posteriormente, adicionaram-se os seguintes componentes: 2,5 $\mu \mathrm{L}$ de tampão de PCR (10X), 2,5 $\mu \mathrm{L}$ de $\mathrm{MgCl}$ (25mM), $1 \mu \mathrm{L}$ de dNTP (10mM) e 2,5 $\mu \mathrm{L}$ de DTT $(0,1 \mathrm{M})$. A mistura foi incubada 
por 1 minuto a $42^{\circ} \mathrm{C}$ onde então, adicionourse $1 \mu \mathrm{L}$ de SUPERSCRIPT ${ }^{\mathrm{TM}} \|$ (Transcriptase Reversa) e deixou-se a amostra sob incubação durante 50 minutos a $42^{\circ} \mathrm{C}$. Após este tempo, para finalizar a reação, incubourse o tubo por 15 minutos a $70^{\circ} \mathrm{C}$. Para degradar a fita de RNA do híbrido cDNA-RNA formado, foi adicionado $1 \mu \mathrm{L}$ de RNAse e a reação incubada a $37^{\circ} \mathrm{C}$ por 30 minutos.

\subsubsection{Purificação do cDNA}

Para purificar e isolar o cDNA obtido dos dNTPs e dos oligonucleotídeos GSP1-TOM não incorporados, o kit 5' RACE apresenta um sistema denominado GlassMAX DNA isolation Spin Cartridge. Nessa etapa, 120 $\mu \mathrm{L}$ da solução Binding Solution ( $\mathrm{Nal}$ 6M) foram adicionados na reação da primeira fita. Essa solução ( $\mathrm{Nal}+\mathrm{CDNA}$ ) foi transferida para um Glass MAX Spin Cartridge que foi então centrifugado a 13000xg (microcentrífuga de mesa) por 20 segundos. O Cartridge foi removido para um novo tubo do tipo Eppendorf. Foram adicionados $400 \mu \mathrm{L}$ do Tampão de Lavagem (do próprio kit) previamente refrigerado $\left(4^{\circ} \mathrm{C}\right)$ e centrifugou-se a amostra a $13000 \times \mathrm{xg}$ (microcentrífuga de mesa) por 20 segundos, onde descartou-se 0 sobrenadante. Esta etapa de lavagem foi repetida 4 vezes. Posteriormente, o Cartridge foi lavado 2 vezes com $400 \mu \mathrm{L}$ de etanol $70 \%\left(4^{\circ} \mathrm{C}\right)$ seguindo $\mathrm{O}$ mesmo procedimento anterior. Após retirar todo o etanol $70 \%$ do fundo do Eppendorf, centrifugou-se por mais 1 minuto à $13000 x g$. O Cartridge foi então transferido para um novo tubo, onde foram adicionados $50 \mu \mathrm{L}$ de água estéril previamente aquecida a $65^{\circ} \mathrm{C}$ para eluir o cDNA. A amostra bi posteriormente centrifugada por 20 segundos a $13000 x g$. 


\subsubsection{Adição de uma cauda homopolimérica (oligo-dC) na extremidade 3' do cDNA purificado utilizando a enzima Deoxinucleotidil Transferase Terminal (TdT)}

Em um tubo do tipo Eppendorf $(0,65 \mathrm{~mL})$ foram adicionados $6,5 \mu \mathrm{L}$ de água estéril, $5 \mu \mathrm{L}$ de Tailing Buffer (5X), $2 \mu \mathrm{L}$ de dCTP (2mM) e $10 \mu \mathrm{L}$ da solução de cDNA purificada com o Cartridge. Essa mistura foi incubada por 2 minutos a $94^{\circ} \mathrm{C}$ e então rapidamente resfriada no gelo por 1 minuto. Adicionour se $1 \mu \mathrm{L}$ de TdT (Deoxinucleotidil transferase terminal) e incubou-se por 10 minutos a $37^{\circ} \mathrm{C}$. Posteriormente, a enzima foi inativada por calor $\left(65^{\circ} \mathrm{C}\right.$ por 10 minutos).

\subsubsection{Reação de PCR com o cDNA dC-Tailed}

Para a reação de amplificação do cDNA dC-Tailed, de forma a conseguir a extremidade $5^{\prime}$ do gene $\mathrm{FtsH}-\mathrm{p} 1$ de tomate, foi necessário utilizar dois oligonucleotídeos: um específico (GSP2-TOM $=5^{\prime}$ CGCCAGAATATCGATTAAATCCGCGTC 3') que se encontra na região 3' do iniciador GSP1-TOM e o AAP (Abridge Anchor Primer = oligonucleotídeo oligoDG + seqüência adaptadora) que é fornecido pelo kit e tem a propriedade de se anelar-se na seqüência poli-C do cDNA dC-Tailed.

Em um tubo de PCR $(0,65 \mathrm{~mL})$ foram adicionados $31,5 \mu \mathrm{L}$ de água esterilizada, 5,0 $\mu \mathrm{L}$ de tampão de PCR (10X). 3,0 $\mu \mathrm{L}$ de MgCb (25mM), 1,0 dNTP (10mM), 2,0 $\mu \mathrm{L}$ (20 picomoles) do oligonucleotídeo GSP2-TOM $(10 \mu \mathrm{M}), 2$ $\mu \mathrm{L}$ (20 picomoles) do iniciador AAP, 5,0 $\mu \mathrm{L}$ de cDNA dC-Tailed e $0,5 \mu \mathrm{L}$ de Taq DNA polimerase (5 unidades/ $\mu \mathrm{L})$. A seguinte reação de amplificação foi utilizada: 
- $94^{\circ} \mathrm{C}$ por 2 minutos

- $\quad 94^{\circ} \mathrm{C}$ por 1 minuto

- $\quad 55^{\circ} \mathrm{C}$ por 1 minuto

- $\quad 72^{\circ} \mathrm{C}$ por 2 minutos

335 ciclos

- $\quad 72^{\circ} \mathrm{C}$ por 7 minutos

\subsubsection{Extração do fragmento 5' FtsH-p1 do gel de agarose}

A metodologia utilizada na extração e purificação do fragmento 5'FtsH-p1 (700 pares de bases) do gel de agarose, assim como as metodologias de clonagem do fragmento obtido no vetor pUC18 foram semelhantes às detalhadas nos itens 3.1 .8 e 3.1.9. As colônias obtidas foram analisadas e confirmadas via sequenciamento (ver metodologia acima)

\subsubsection{Obtenção da extremidade 3' do gene FtsH-p1 à partir do fragmento clonado no item 3.1.9.}

\subsubsection{Isolamento do RNA total}

A metodologia utilizada na extração do RNA total foi detalhada anteriormente no item 3.1.4.2.

\subsubsection{Síntese da primeira fita do cDNA}

Para a síntese da primeira fita de cDNA foi necessário utilizar um ologonucleotídeo que além da região rica em timinas (oligo dT) apresenta uma região adaptadora necessária para o reconhecimento de um segundo oligonucleotídeo (oligo-d(T)-anchor 5’ GACCACGCGTATCGATGTCGAC(T) 18 da Boehringer). Este oligo foi gentilmente cedido pela professora Maria de 
Fátima Grossi de Sá, do Centro Nacional de Recursos Genéticos e Biotecnologia (CENARGEN/EMBRAPA).

Em um tubo do tipo Eppendorf $(0,65 \mathrm{~mL})$ foram adicionados $2 \mu \mathrm{L}$ de oligo $\mathrm{d}(\mathrm{T})$-anchor (25 picomoles), $5 \mu \mathrm{L}$ de amostra de RNA total (aproximadamente $5 \mu \mathrm{g}$ ) e $8,5 \mu \mathrm{L}$ de água estéril tratada com DEPC. A mistura foi então incubada por 10 minutos a $70^{\circ} \mathrm{C}$ para desnaturar o RNA. O ubo foi colocado no gelo por 1 minuto onde, posteriormente, adicionaram-se os seguintes componentes: 2,5 $\mu \mathrm{L}$ de tampão de PCR (10X), 2,5 $\mu \mathrm{L}$ de $\mathrm{MgCl}$ (25mM), $1 \mu \mathrm{L}$ de dNTP (10mM) e 2,5 $\mu \mathrm{L}$ de DTT (0,1M). A mistura foi incubada por 1 minuto a $42^{\circ} \mathrm{C}$ onde então, adicionou-se $1 \mu \mathrm{L}$ de SUPERSCRIPT ${ }^{\mathrm{TM}} \|$ (Transcriptase Reversa) e deixou-se sob incubação durante 50 minutos a $42^{\circ} \mathrm{C}$. Após este tempo, para finalizar a reação, incubou-se o tubo por 15 minutos a $70^{\circ} \mathrm{C}$. Para degradar a fita de RNA do híbrido cDNA-RNA formado, foi adicionado $1 \mu \mathrm{L}$ de RNAse e a reação incubada a $37^{\circ} \mathrm{C}$ por 30 minutos.

\subsubsection{Reação de PCR para a obtenção da região 3'FtsH-p1 de tomate}

Para obter a extremidade 3' do gene FtsH-p1 de tomate, foi necessário utilizar um oligonucleotídeo específico (GSP1-TOM4= 5'TTCCTCGAGGCCAAGCCGGTGGTC 3') e um oligonucleotídeo que se anela especificamente à região adaptadora do iniciador oligo $\mathrm{d}(\mathrm{T})$-anchor (dT-AP), o Anchor Primer (AP).

Em um tubo de PCR $(0,65 \mathrm{~mL})$ foram adicionados $31,5 \mu \mathrm{L}$ de água esterilizada, 5,0 $\mu \mathrm{L}$ de tampão de PCR (10X), 3,0 $\mu \mathrm{L}$ de $\mathrm{MgCb}(25 \mathrm{mM}), 1,0$ dNTP (10mM), 2,0 $\mu \mathrm{L}$ (20 picomoles) do iniciador GSP1 (tomato 4) (10 $\mu \mathrm{M}), 2 \mu \mathrm{L}$ (25 picomoles) do iniciador AP, 5,0 $\mu \mathrm{L}$ de cDNA produzido na reação anterior e $0,5 \mu \mathrm{L}$ de Taq DNA polimerase (5 unidades $/ \mu \mathrm{L}$ ). A seguinte reação de amplificação foi utilizada: 
- $94^{\circ} \mathrm{C}$ por 2 minutos

- $\quad 94^{\circ} \mathrm{C}$ por 1 minuto

- $\quad 55^{\circ} \mathrm{C}$ por 1 minuto

- $\quad 72^{\circ} \mathrm{C}$ por 2 minutos

335 ciclos

- $\quad 72^{\circ} \mathrm{C}$ por 7 minutos

\subsubsection{Extração do fragmento 3' FtsH-p1 do gel de agarose}

A metodologia utilizada na extração do fragmento 3'FtsH-p1 do gel de agarose bem como sua clonagem no vetor pUC18, transformação de células bacterianas (JM 109) e sequenciamento, foram desenvolvidas de forma semelhante æ̀s detalhadas nos itens 3.1.8, 3.1.9, 3.1.12 e 3.1.15.

\subsubsection{Obtenção do cDNA completo da FtsH-p1 de tomate utilizando DNA polimerase de alta fidelidade.}

Para evitar a formação de quimeras entre os diferentes fragmentos clonados (uma vez que existem parálogos com alta similaridade entre as seqüências), resolveu-se amplificar o CDNA da FtsH-p1 de tomate fazendo-se uso da DNA polimerase Pfu (Promega). Para isso, dois oligos específicos foram desenhados de forma a anelarem-se às extremidades lider (5' UTR) e (3'UTR) do cDNA da FtsH-p1 de tomate:

LIDER= 5' CCCAGATCTCCAATGGCCAATGCT 3' e TRAILER= 5' CACCAATGTATCTTCCCCACTC 3'

\subsubsection{Reação de PCR com a DNA polimerase Pfu}

Na reação foram utilizados cerca de $1 \mu \mathrm{g}$ de cDNA (proveniente da reação RT-PCR de RNA extraídos de frutos de tomate), 5uL de tampão de reação (10X concentrado) contendo $\mathrm{MgSO}_{4}, 200 \mu \mathrm{M}$ de dNTPs, $1 \mu \mathrm{M}$ de cada 
oligo específico (LIDER e TRAILER) e 1,5 unidades da enzima Pfu. O fragmento obtido foi clonado no vetor pUC18 e confirmado, via sequenciamento, corresponder ao cDNA completo da FtsH-p1 de tomate.

\subsubsection{Construções gênicas envolvendo a região amino-terminal da FtsH- p1 e clonagem no vetor binário para transformação de plantas.}

As construções gênicas contendo diferentes comprimentos da região aminoterminal da FtsH-p1 de tomate e o gene repórter mGFP5 que codifica para a green fluorescent protein (GFP) dirigidas por um promotor de expressão em plantas (35S) foram realizadas da seguinte forma:

Para a realização da construção 35S-TP-GFP, dois iniciadores foram desenhados a fim de amplificarem a região correspondente ao primeiro ATG até alguns aminoácidos após o possível ponto de clivagem do peptídeo de trânsito predito utilizando-se programa apropriado (Nielsen et al., 1997). Os iniciadores utilizados para amplificação apresentavam em suas extremidades, sítios de restrição (Bg/ll e Spel, respectivamente) para facilitar a clonagem e foram preparados de forma a estarem em fase de leitura com o vetor de expressão em plantas (pCambia 1302) (Roberts et al., 1997).

ATG: 5' CCCAGATCTCCAATGGCCAATGCT 3' (utilizado em todas as $B g l$ II construções).

TP: 5'CCCACTAGTAGCAGCTTTAGATGG 3'

A segunda construção (35S-TP-H1-GFP), compreendeu todo o peptídeo de trânsito e a região que codifica para a primeira região hidrofóbica (H1). Os iniciadores utilizados foram o ATG (citado acima) e o: 


\section{H1: 5'CCCACTAGTAGGTTTTGGTGCTTCAGC 3'}

A terceira (35S-TP-H1-loop-GFP) é formada pelo peptídeo de trânsito (TP), o primeiro domínio hidrofóbico $(\mathrm{H} 1)$ mais a região hidrofílica

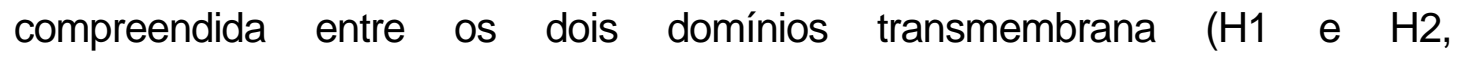
respectivamente). Finalmente, o quarto gene quimérico (35S-TP-H1-loop-H2GFP) compreendeu o peptídeo de trânsito até o final da segunda região hidrofóbica $(\mathrm{H} 2)$ mais 11 aminoácidos da proteína madura. Iniciadores utilizados:

LOOP: 5' CCCACTAGTCCCATTACCCCCTTCACC 3'

H2: 5' CCCACTAGTTCCAGGCCCACCTGGCGG 3'

\subsubsection{Amplificação dos fragmentos}

Os iniciadores acima foram utilizados para amplificar os fragmentos desejados utilizando-se como molde, o vetor pUC18 FtsH-p1 (completa) amplificado anteriormente com a enzima Pfu. Nas reações de amplificação, foram utilizados $1 \mu \mathrm{g}$ de DNA molde, 5,0 $\mu \mathrm{L}$ de tampão de PCR (10X concentrado), $2 \mu \mathrm{L}$ de cloreto de magnésio (50 mM), $1 \mu \mathrm{L}$ de um mix de dNTPs (10mM), 30 picomoles de cada iniciador específico e 0,5 unidades de Taq DNA polimerase.

\subsubsection{Restrição dos fragmentos e do vetor de expressão em plantas}

Os fragmentos TP, TP-H1, TP-H1-loop, TP-H1-Loop-H2 foram digeridos com as enzimas Spel e Bg/ll. Após purificação, estes fragmentos 
foram inseridos dentro dos sítios correspondentes do vetor binário utilizado para transformação de plantas (pCAMBIA 1302) produzindo os vetores de transformação pCAMBIA-35S-TP-GFP-NOS, pCAMBIA-35S-TP-H1-GFP-NOS, pCAMBIA-35S-TP-H1-loop-GFP-NOS e pCAMBIA-35S-TP-H1-loop-H2-GFPNOS, respectivamente.

\subsubsection{Ensaio de expressão transiente da GFP em células epidérmicas de cebola}

Na técnica de bombardeamento de micropartículas utilizada, cerca de $1 \mu \mathrm{g}$ de DNA plasmidial (pCAMBIA+construções) foi precipitado sobre partículas de tungstênio (50 $\mu \mathrm{L}$ de solução $60 \mathrm{ng} / \mu \mathrm{L}$ ) através de mistura contendo cloreto de cálcio (50 $\mu \mathrm{L}$ de solução $2,5 \mathrm{M}$ ) e espermidina "free base" (20 $\mu \mathrm{L}$ de solução $0,1 \mathrm{M}$ ). Esta mistura foi centrifugada por 2 minutos a 12000 rpm em microcentrífuga de mesa e o "pellet" lavado duas vezes em etanol 95\% sendo, finalmente, ressolubilizado em $25 \mu \mathrm{L}$ de etanol 95\%. Quatro microlitros desta mistura foram usados no bombardeamento de cada placa de Petri contendo "fatias" (camadas) de cebola que estavam posicionadas no centro das placas, formando uma área alvo circular de cerca de $2 \mathrm{~cm}$ de diâmetro. As partículas, recobertas com o DNA de interesse, foram aceleradas em direção a este tecido e todos os parâmetros referentes aos disparos foram realizados conforme metodologia descrita pelo fabricante (BioRad). Após o bombardeamento as epidermes de cebola foram incubadas a $22^{\circ} \mathrm{C}$ no escuro por 19 horas (Giglione et al., 2000). A visualização da GFP foi realizada em microscópio de fluorescência (Axiophot2-Zeiss), com os filtros FITC (450-490) e H546 (Zeiss). 


\subsubsection{Transformação de Agrobacterium tumefaciens}

A transformação de $A$. tumefaciens (LBA4404) foi realizada da seguinte maneira: $2 \mathrm{~mL}$ de uma cultura de células de $A$. tumefaciens, crescidas durante a noite, a $28^{\circ} \mathrm{C}$, foram inoculados em $50 \mathrm{~mL}$ de meio $\mathrm{LB}$ e mantidos sob agitação até atingir a densidade óptica $\left(\mathrm{OD}_{600 \mathrm{~nm}}\right)$ de aproximadamente 0,5 . A cultura foi, então, centrifugada a $5000 \mathrm{rpm}$ por 5 minutos, a $4^{\circ} \mathrm{C}$. O sobrenadante foi descartado e as células ressuspendidas em $1 \mathrm{~mL}$ de $\mathrm{CaCl}_{2}$ (20mM) gelado. Cerca de $1 \mu \mathrm{g}$ de DNA plasmidial, extraído via QIAGEN, das construções (pCAMBIA-35S-TP-GFP-NOS, pCAMBIA-35S-TP-H1-GFP-NOS, pCAMBIA-35S-TP-H1-loop-GFP-NOS, pCAMBIA-35S-TP-loop-H2-GFP-NOSGFP e pCAMBIA 35S-GFP-NOS) foram adicionados a $100 \mu \mathrm{L}$ das células competentes e incubados no gelo por 30 minutos. Após este período, a mistura foi congelada em nitrogênio líquido e, a seguir, descongelada em banho $\left(37^{\circ} \mathrm{C}\right)$ por 5 minutos. $1 \mathrm{~mL}$ de LB foi adicionado e as células foram mantidas sob agitação a $28^{\circ} \mathrm{C}$ por 2 horas. Os tubos foram centrifugados por 30 segundos em microcentrífuga de mesa e o sobrenadante, descartado. As células foram ressuspendidas em 100 $\mu \mathrm{L}$ de LB, plaqueadas em LB ágar + canamicina $(100 \mu \mathrm{g} / \mathrm{mL})+$ rifampicina $(50 \mu \mathrm{g} / \mathrm{mL})$ e incubadas a $28^{\circ} \mathrm{C}$ por cerca de 2 dias.

\subsubsection{Transformação de plantas de Nicotiana tabacum com as construções pCAMBIA-35S-TP-GFP-NOS, pCAMBIA-35S-TP-H1- GFP-NOS, pCAMBIA-35S-TP-H1-loop-GFP-NOS e pCAMBIA-35S- TP-H1-loop-H2-GFP-NOS.}

Discos foliares de aproximadamente $1 \mathrm{~cm}^{2}$ foram retirados de plantas de Nicotiana tabacum, variedade SRI, crescidas in vitro, e colocados em meio MS (Murashige \& Skoog, 1962). Os discos foram perfurados com uma agulha contendo A. tumefaciens transformada com as construções. Após 3 
dias, os discos foliares foram transferidos para meio de cultura MS + higromicina $(25 \mu \mathrm{g} / \mathrm{mL})+$ carbenicilina $(400 \mu \mathrm{g} / \mathrm{mL})+$ cefotaxime $(500 \mu \mathrm{g} / \mathrm{mL})+$ IAA $(0,2 \mu \mathrm{g} / \mathrm{mL})+6$-BAP $(2,2 \mu \mathrm{g} / \mathrm{mL})$, que permite a regeneração (organogênese) das plantas transformadas resistentes à higromicina. $O$ enraizamento foi favorecido pela transferência das plântulas pelo meio MSAKC. Posteriormente, as plântulas enraizadas foram transferidas para vasos e aclimatadas em casa de vegetação, juntamente com plantas selvagens (WT) que serviram de controle.

\subsubsection{Extração de DNA e verificação da presença do T-DNA nas plantas}

A fim de detectar a presença do T-DNA nas plantas obtidas, procedeu-se a análise por PCR utilizando-se de iniciadores específicos. A extração de DNA foi efetuada usando-se o protocolo descrito por Edwards et al., (1991). Discos foliares com cerca de $0,5 \mathrm{~cm}^{2}$ foram coletados usando a tampa estéril do próprio tubo tipo Eppendorf. O tecido foi macerado sem adição de tampão à temperatura ambiente por 15 segundos. Foram adicionados 400 $\mu \mathrm{L}$ de tampão de extração (200mM de Tris $\mathrm{HCl}$ pH 7,5, $200 \mathrm{mM}$ de $\mathrm{NaCl}, 25$ $\mathrm{mM}$ de EDTA e $0,5 \%$ de SDS) e os tubos agitados por 5 segundos. O extrato foi centrifugado (13000 rpm em microcentrífuga de mesa) por 1 minuto e $300 \mu \mathrm{L}$ do sobrenadante foram transferidos para novos Eppendorfs. Após esse procedimento, foram adicionados $300 \mu \mathrm{L}$ de isopropanol e a solução resultante foi deixada em repouso por 2 minutos em temperatura ambiente. Os tubos Eppendorfs foram centrifugados (13000 rpm em microcentrífuga de mesa) por 5 minutos e os sobrenadantes descartados. Os precipitados, após a secagem, foram dissolvidos em $100 \mu \mathrm{L}$ de $1 \mathrm{X}$ Tris EDTA (TE) composto de $10 \mathrm{mM}$ de Tris- $\mathrm{HCl}$ pH 7,6 e 1 mM de EDTA pH 8,0. As condições utilizadas nas reações de PCR, após a otimização para todas as construções, foram as seguintes: 5 $\mu \mathrm{L}$ do DNA extraído, 0,6 $\mu \mathrm{L}$ de dNTP 2,5 mM, 1 unidade de Taq DNA polimerase, 5,0 $\mu \mathrm{L}$ de tampão de reação $10 \mathrm{X}$ concentrado e 30 picomoles de 
cada iniciador. A reação de amplificação utilizada consistiu de 35 ciclos cada um composto de desnaturação $\left(95^{\circ} \mathrm{C}\right.$ por 45 segundos), anelamento $\left(55^{\circ}\right.$ por 45 segundos) e elongação ( $73^{0}$ por 150 segundos).

\subsubsection{Expressão dos transgenes}

\subsubsection{Extração de proteínas totais}

Aproximadamente $1 \mathrm{~g}$ de folha fresca foi macerado em nitrogênio líquido e cerca de $2,5 \mathrm{~mL}$ de tampão de extração composto de $0,1 \mathrm{M}$ de Tris-Cl $\mathrm{pH} 7,6$ e $0,1 \%(\mathrm{p} / \mathrm{v})$ de ácido ascórbico foi adicionado à amostra. Ao descongelar, o extrato foi recolhido em tubos Eppendorfs e centrifugado por 2 minutos a $14000 \mathrm{rpm}$ em microcentrífuga de mesa. Após a centrifugação, o sobrenadante foi coletado em novos tubos Eppendorfs e armazenados a $-80^{\circ} \mathrm{C}$ para as posteriores análises.

\subsubsection{Análise da concentração de proteínas}

O teor de proteína no extrato foi determinado com base no método descrito por Bradford (1976), onde $10 \mu \mathrm{L}$ de extrato das amostras foram adicionados a $1 \mathrm{~mL}$ do reagente de Bradford (50 mg Coomassie Briliant Blue G250 , dissolvido em $25 \mathrm{~mL}$ de etanol, aos quais adiciona-se $50 \mathrm{~mL}$ de ácido fosfórico e completa-se o volume a $500 \mathrm{~mL}$ com água) para reagir por 2 minutos. Após a reação, determinou-se a concentração protéica das amostras via espectrofotômetro com base na densidade ótica a $595 \mathrm{~nm}$ tomando-se como base uma curva padrão construída com BSA (soro de albumina bovina) em

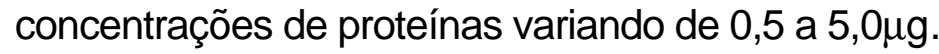




\subsubsection{Eletroforese}

As proteínas $(\sim 10 \mu \mathrm{g})$ foram solubilizadas em $80 \mathrm{mM}$ de Tris-Cl, $2 \%(\mathrm{p} / \mathrm{v})$ de SDS, $10 \%(\mathrm{p} / \mathrm{v})$ de glicerol, 0,005\% (p/v) de azul de bromofenol e $1 \%(\mathrm{p} / \mathrm{v})$ de dithiothreitol, $\mathrm{pH} 6,8(\mathrm{HCl})$ por 15 minutos a $56^{\circ} \mathrm{C}$, e, então, separadas eletroforeticamente por SDS em gel de poliacrilamida (Laemmli, 1970), à voltagem constante de $100 \mathrm{~V} / \mathrm{gel}$. As proteínas foram transferidas para uma membrana de nitrocelulose $(0,45 \mu \mathrm{m})$ da BioRad utilizando amperagens de: $75 \mathrm{~mA}$ por 12 minutos, $175 \mathrm{~mA}$ por 15 minutos, $400 \mathrm{~mA}$ por 25 minutos e, finalmente, $450 \mathrm{~mA}$ por 10 minutos.

\subsubsection{Imunodetecção}

Após a transferência, a membrana de nitrocelulose foi lavada, sob agitação, com aproximadamente $50 \mathrm{~mL}$ de tampão fosfato salino (PBS) composto de $137 \mathrm{mM}$ de $\mathrm{NaCl}, 2,68 \mathrm{mM}$ de $\mathrm{KCl}, 30,25 \mathrm{mM}$ de $\mathrm{NaH}_{2} \mathrm{PO}_{4}, 1,76$ $\mathrm{mM}$ de $\left.\mathrm{KH}_{2} \mathrm{PO}_{4}, \mathrm{pH} 7,4\right)$ durante 5 minutos. A seguir, foi saturada com uma solução contendo $5 \%$ de leite em pó desnatado e 0,2\% (v/v) de Tween 20. A membrana foi lavada 3 vezes por 10 minutos com tampão Tris salino (TBS) + $0,1 \%$ ( $v / v)$ Tween 20, e incubada por 1 hora com os diferentes anticorpos em TBS (várias diluições testadas). Após a incubação com o anticorpo primário (anti-GFP-1:5000; anti-LHCP-1:40000 e anti-SRP-54 1:10000), a membrana foi novamente lavada 3 vezes por 10 minutos em TBS contendo $0,1 \%$ de Tween 20 (v/v) e incubada por uma hora com o anticorpo secundário anti-rabbit IgG conjugado com a fosfatase alcalina (Promega) na diluição de 1/10.000. Novamente, a membrana foi lavada 3 vezes por 10 minutos em TBS contendo $0,1 \%$ de Tween $20(\mathrm{v} / \mathrm{v})$ e revelada com o produto FAST BCIP/NBT (SIGMA), conforme recomendações do fornecedor.

Os anticorpos anti-LHCP e o anti-SRP54 foram gentilmente cedidos pelo Prof. Ken Cline (University of Florida, USA). O anticorpo primário anti-GFP foi adquirido da Invitrogen. 


\subsubsection{Isolamento de cloroplastos e tilacóides}

Para o isolamento de cloroplastos, cerca de 10 gramas de folhas foram lavadas com uma solução aquosa de $0,1 \%$ de Tween 20 . Todos os passos subsequentes foram realizados a $4^{\circ} \mathrm{C}$. As folhas foram colocadas em um liquidificador contendo $100 \mathrm{~mL}$ de tampão de homogenização [0,33M de sacarose, $50 \mathrm{mM}$ de Tris- $\mathrm{Cl} \mathrm{pH} 8,0,0,2 \%(\mathrm{p} / \mathrm{v})$ de BSA, 0,04\% (v/v) de $\beta$ mercaptoetanol e $0,2 \%(\mathrm{p} / \mathrm{v})$ de PVP (polivinilpirrolidona) insolúvel] e 3 a 5 pulsos foram efetuados para o completo rompimento celular. $O$ homogenizado foi filtrado utilizando-se 2 camadas de papel Miracloth e duas frações de $1 \mathrm{~mL}$ foram recolhidas em tubos Eppendorf. Um dos tubos foi mantido no gelo [homogenizado $(\mathrm{H})$ ] e o outro centrifugado por 5 minutos a $13000 \mathrm{rpm}$ (microcentrífuga de mesa). Deste último, separa-se o precipitado $(P)$ e 0 sobrenadante citossólico (S) em outros tubos Eppendorfs. O restante do homogenizado filtrado foi centrifugado (3 minutos, $3.500 \mathrm{rpm}$, rotor Sorvall STmicro). O sobrenadante foi eliminado e o precipitado ressuspendido em $2 \mathrm{~mL}$ de tampão de suspensão [0,4M de manitol, $10 \mathrm{mM}$ de KH2PO4 pH 7,2, 0,2\% (p/v) BSA]. Essa amostra foi adicionada sobre dois gradientes de Percoll preparados em um tubo "Corex" [ $4 \mathrm{~mL}$ de Percoll $80 \%$ (v/v), 0,25M de sacarose e 4,8mL de Percoll 40\% (v/v), 0,25M de sacarose]. Os tubos Corex foram centrifugados por 10 minutos, 10000rpm, rotor HL-50T da Sorvall. Após a centrifugação, a fração enriquecida de cloroplastos foi coletada na interface das camadas de Percoll e diluídos em tampão de suspensão sem BSA. As amostras foram centrifugadas por 3 minutos a $3500 \mathrm{rpm}$ no rotor HL-50T. O sobrenadante foi descartado e 0 precipitado ressuspendido em $1 \mathrm{~mL}$ de tampão de suspensão sem BSA. Essa etapa foi repetida várias vezes para eliminação do Percoll. O precipitado final foi ressuspendido em $100 \mu \mathrm{L}$ de tampão de suspensão sem BSA. Esse isolamento de cloroplastos foi adaptado de Bartlet et al., (1982), Pilon et al., (1992) e SilvaFilho et al., (1997). Para o isolamento das frações correspondentes ao estroma (proteínas solúveis) e membranas dos tilacóides (fração insolúvel), da fração 
enriquecida de cloroplastos, nós utilizamos a técnica desenvolvida por Schuler \& Zielinski (1989). Para isso, aproximadamente $50 \mu \mathrm{g}$ de cloroplastos isolados (intactos) foram ressuspendidos em $200 \mu \mathrm{L}$ de tampão de lise composto de 62,5 M de Tris. Cl pH 7,5 e 2mM de $\mathrm{MgCl}_{2}$. Essa mistura foi incubada por 15 minutos no gelo sendo ocasionalmente (2 em 2 minutos) agitada vigorosamente. Após esse período de incubação, a amostra foi centrifugada por cerca de 5 minutos $(12000 \mathrm{xg})$. O sobrenadante, composto de fração solúvel, foi alíquotado e armazenado. O "pellet" foi novamente ressuspendiido em $200 \mu \mathrm{L}$ de tampão de lise e centrifugado por 5 minutos (12000xg). O "pellet" resultante, composto da fração insolúvel dos tilacóides, foi ressuspendido em $10 \mu \mathrm{L}$ de água destilada e também armazenado.

\subsection{Clonagem da região promotora do gene FtsH-p1, utilizando a técnica PCR-TAIL}

Para clonar a região 5' flanqueadora do gene FtsH-p1, optou-se por utilizar uma técnica denominada PCR-TAIL (thermal asymmetric interlaced PCR), desenvolvida por Liu \& Whittier em 1995. Ela consiste em utilizar iniciadores específicos em combinação com iniciadores curtos, degenerados e de seqüências arbitrárias. Um programa de PCR bastante elaborado composto de superciclos contendo um ciclo de baixa estringência e dois de alta estringência permite que apenas os fragmentos seqüência específicos sejam exponencialmente amplificados

$\mathrm{Na}$ tentativa de clonar a região promotora do gene utilizando desta técnica, 7 iniciadores arbitrários e degenerados e 9 oligos que se anelavam especificamente na região 5' do gene FtsH-p1, foram desenhados baseando-se nos procedimentos descritos por Liu \& Whittier (1995). 
Iniciadores arbitrários (AP):

AP1: 5' NTCGA(G/C)T(A/T)T(C/C)G(A/T)GTT 3'

AP2: 5' NGTCGA(G/C)?(A/T)GANA(A/T)GAA 3'

AP3: 5' (A/T)GTGNAG(A/T)ANCANAGA 3'

AP4: 5' TG(A/T)GNAG(A/T)ANCA(G/C)AGA 3'

AP5: 5' AG(A/T)GNAG(A/T)ANCA(A/T)AGG 3'

AP6: 5' CA(A/T)CGICNGAIA(G/C)GAA 3'

ÁP7: 5' TC(G/C)TICGNACIT(A/T)GGA 3'

Iniciadores específicos (EP):

TAIL1: 5' GTACAGCATTGGCCATTGGTGG 3'

TAlL2: 5' TGGGAACCCAAGAAATTGGAA 3'

TAIL3: 5' GGTGTGGGAGGAGAAACAAAG 3'

TAIL4: 5' GGAGTGAAGATGGAAATACCTTGAGGTT 3'

TAIL5: 5' GATAGTTTCCCAAGGG 3'

TAIL6: 5' CCCAAGGGTTATATTT 3'

TAIL7: 5' CGTTTGCATGACTAGC 3'

TAIL8: 5' GTTTTTCCTCCCTACC 3'

TAIL9: 5' CAAGGTATTTCCATCT 3'

Para o sucesso da técnica PCR-TAIL, o isolamento e purificação de DNA é uma etapa bastante importante, pois requer que este esteja livre de polissacarídeos, substâncias fenólicas e compostos secundários. Para contornar esses problemas, optoutse por utilizar o método de extração baseado no uso do detergente CTAB (Brasileiro et al., 1998). Na extração, 3 gramas de material vegetal fresco foram colocados em um almofariz e imediatamente pulverizados com nitrogênio líquido. $O$ material obtido foi rapidamente transferido para um tubo de polipropileno de $50 \mathrm{~mL}$ contendo $15 \mathrm{~mL}$ de tampão CTAB [CTAB 2\% (p/v); NaCl 1,4 M; Tris-HCl 100 mM, pH 8,0; EDTA 20 mM; $\beta$ mercaptoetanol $0,2 \%(\mathrm{v} / \mathrm{v})$ ] pré aquecido a $65^{\circ} \mathrm{C}$. Fechourse o tubo e misturout se gentilmente até o pó ficar homogeneamente distribuído. A amostra foi incubada em banho-maria a $60^{\circ} \mathrm{C}$ por 30 minutos, agitando-se ocasionalmente o tubo para que o extrato ficasse ressuspendido. Após este aquecimento, deixou-se a mistura atingir a temperatura ambiente, quando foram adicionados $15 \mathrm{~mL}$ de uma solução composta de clorofórmio:álcool isoamílico (24:1; v/v). A 
mistura foi agitada manualmente por 10 minutos. $O$ tubo foi centrifugado a $5000 x g$ por 10 minutos a temperatura ambiente, para a separação da fase orgânica da fase aquosa. A fase superior (fase aquosa) foi transferida para um novo tubo de $50 \mathrm{~mL}$ e a extração clorofórmio:álcool isoamílico repetida mais duas vezes. Posteriormente, RNAse A (concentração final de $100 \mathrm{mg} / \mathrm{mL}$ ) foi adicionada ao tubo que foi incubado a $37^{\circ} \mathrm{C}$ por 30 minutos. Adicionaram-se 0,6 volumes de isopropanol a $-20^{\circ} \mathrm{C}$ àmistura que foi agitada suavemente até formar uma rede de filamentos visíveis, que foi recuperado com o auxílio de uma pipeta. Depois de secos, os filamentos foram ressuspendidos em $5 \mathrm{~mL}$ de tampão $\mathbb{E}$ (Tris- $\mathrm{HCl} 10 \mathrm{mM}$, pH 8,0; EDTA $1 \mathrm{mM}$ ) e armazenados a $-20^{\circ} \mathrm{C}$. Nenhuma etapa extra de purificação foi realizada.

\subsubsection{PCR-TAIL}

Para a primeira reação de PCR (PCR primário) utilizourse cerca de $200 \mathrm{ng}$ de DNA genômico, $2 \mathrm{mM}$ de $\mathrm{MgCl}_{2}, 400 \mathrm{nM}$ do iniciador específico TAIL4, $3 \mu \mathrm{M}$ do iniciador arbitrário (um para cada tubo de reação), $200 \mu \mathrm{M}$ de dNTP e 1 unidade de Taq DNA polimerase para um volume final de $20 \mu \mathrm{L}$. Após o término do PCR primário, $1 \mu \mathrm{L}$ de uma diluição de $1 / 50$ de cada tubo de reação do PCR primário foi utilizada como DNA molde na reação secundária. Foram em seguida adicionados $400 \mathrm{nM}$ do iniciador específico 3 (TAIL3) e $2 \mu \mathrm{M}$ do mesmo iniciador arbitrário utilizado no tubo da reação primária. Os outros componentes foram utilizados na mesma concentração da reação primária. $\mathrm{Na}$ reação terciária, foi usado $1 \mu \mathrm{L}$ de uma diluição $1 / 10$ das reações secundárias com os iniciadores específicos TAIL2 e TAIL1 (400 nM) mais $0,2 \mu \mathrm{M}$ do iniciador arbitrário comum. A solução de reação compreendeu todos os componentes nas mesmas concentrações das reações anteriores. Abaixo estão listados os ciclos usados no PCR TAIL. 


\begin{tabular}{|c|c|c|c|}
\hline Reação & Programa & $\mathbf{N}^{9}$ Ciclos & Temperaturas/tempos \\
\hline \multirow{5}{*}{ Primário } & 1 & 1 & $93^{\circ} \mathrm{C}, 1 \mathrm{~min} ; 95^{\circ} \mathrm{C}, 1 \mathrm{~min}$ \\
\hline & 2 & 5 & $94^{\circ} \mathrm{C}, 30 \mathrm{seg} ; 55^{\circ} \mathrm{C}, 1 \mathrm{~min} ; 72^{\circ} \mathrm{C}, 2,5 \mathrm{~min}$ \\
\hline & 3 & 1 & $\begin{array}{c}94^{\circ} \mathrm{C}, 30 \text { seg; } 25^{\circ} \mathrm{C}, 3 \mathrm{~min} ; \text { ramping para } \\
72^{\circ} \mathrm{C}(\mathrm{em} 3 \mathrm{~min}), 72^{\circ} \mathrm{C}, 2,5 \mathrm{~min}\end{array}$ \\
\hline & 4 & 15 & $\begin{array}{l}94^{\circ} \mathrm{C}, 10 \mathrm{seg} ; 60^{\circ} \mathrm{C}, 1 \mathrm{~min} ; 72^{\circ} \mathrm{C}, 2,5 \mathrm{~min} ; \\
94^{\circ} \mathrm{C}, 10 \mathrm{seg} ; 60^{\circ} \mathrm{C}, 1 \mathrm{~min}, 72^{\circ} \mathrm{C}, 2,5 \mathrm{~min} ; \\
94^{\circ} \mathrm{C}, 10 \mathrm{seg} ; 35^{\circ} \mathrm{C}, 1 \mathrm{~min}, 72^{\circ} \mathrm{C}, 2,5 \mathrm{mi}\end{array}$ \\
\hline & 5 & 1 & $72^{\circ} \mathrm{C}, 2,5 \min$ \\
\hline \multirow[t]{2}{*}{ Secundário } & 6 & 12 & $\begin{array}{l}94^{\circ} \mathrm{C}, 30 \mathrm{seg} ; 50^{\circ} \mathrm{C}, 1 \mathrm{~min}, 72^{\circ} \mathrm{C}, 2,5 \mathrm{~min} \\
94^{\circ} \mathrm{C}, 30 \mathrm{seg} ; 50^{\circ} \mathrm{C}, 1 \mathrm{~min}, 72^{\circ} \mathrm{C}, 2,5 \mathrm{~min} \\
94^{\circ} \mathrm{C}, 30 \text { seg; } 35^{\circ} \mathrm{C}, 1 \mathrm{~min}, 72^{\circ} \mathrm{C}, 2,5 \mathrm{~min}\end{array}$ \\
\hline & 5 & 1 & $72^{\circ} \mathrm{C}, 2,5 \mathrm{~min}$ \\
\hline \multirow{2}{*}{ Terciário } & 7 & 20 & $94^{\circ} \mathrm{C}, 15 \mathrm{seg} ; 35^{\circ} \mathrm{C}, 1 \mathrm{~min}, 72^{\circ} \mathrm{C}, 2,5 \mathrm{~min}$ \\
\hline & 5 & 1 & $72^{\circ} \mathrm{C}, 2,5 \min$ \\
\hline
\end{tabular}

Quadro 1 - Parâmetros utilizados no programa PCR-TAIL.

\subsubsection{Clonagem e sequenciamento dos fragmentos obtidos nas reações PCR-TAIL e busca por motivos regulatórios}

Os fragmentos provenientes das reações PCR-TAlL foram purificados do gel de agarose e, posteriormente, clonados no vetor pUC18 utilizando-se o kit Sure Clone Ligation (Amersham Pharmacia Biotech) conforme metodologia já descrita (3.1.9). Esses fragmentos foram sequenciados e suas seqüências analisadas pelo programa PLACE "database" (http:/www.dna.affrc.go.jp/htdocs/PLACE/) que realiza buscas de motivos regulatórios na sequência em questão, através de comparações com uma biblioteca contendo sítios de ligação a fatores de transcrição encontrados em promotores de plantas. 


\subsubsection{Deleções e clonagem dos fragmentos no vetor pCAMBIA $1281 Z$}

Para as analisar e verificar quais motivos regulatórios eram realmente importantes tanto para a expressão temporal quanto espacial e descobrir qual era a região promotora mínima, resolvemos realizar várias construções gênicas envolvendo o gene repórter uidA, que codifica a enzima Bglucuronidase (GUS). Para isso foi utilizado o vetor pCambia $1281 Z$ que foi devidamente projetado para a clonagem e caracterização de regiões promotoras em plantas (Roberts et al, 1997).

\subsubsection{Construções gênicas envolvendo a região promotora da FtsH-p1 e clonagem no plasmídio binário para transformação de plantas (pCambia 1281Z).}

Para identificação da região promotora mínima, bem como a contribuição das diferentes regiões no padrão de atividade do promotor, quatro construções gênicas foram realizadas.

Para a primeira construção (GUS 1), dois iniciadores foram desenhados a fim de amplificarem a região correspondente ao início do transcrito (+1) sem entretanto abranger a possível região TATA-BOX. Os iniciadores utilizados para a amplificação apresentavam em suas extremidades, sítios de restrição para facilitar a clonagem e foram preparados de forma a estarem em fase de leitura com o vetor de expressão em plantas. É importante salientar que o iniciador PROMOGUS 5 foi utilizado em todas as construções.

PROMOGUS 1: 5' CCCGGATCCGAAGATGGAAATAC 3' Bam H I

PROMOGUS 5: 5' CCCCCATGGTGGAACAAGATTT 3'

Nco I 
A segunda construção (GUS 2), compreendeu um fragmento de aproximadamente 370 pares de bases que englobava a região TATA BOX mais alguns motivos provavelmente regulados pela luz de acordo com o programa PLACE "database" (http://www.dna.affrc.go.jp/htdocs/PLACE/). O iniciador desenhado para amplificar esse fragmento foi:

\section{PROMOGUS 2: 5' CCCGGATCCGGCCCAATTCTCT 3'}

$$
\text { Bam H I }
$$

A terceira construção (GUS 3), compreendeu um fragmento de 650 pares de bases e a (GUS 4) o fragmento completo (1700 pares de bases).

\section{PROMOGUS 3: 5' CCCGGATCCGAAGATGGAAATAC 3'}

Bam H I

PROMOGUS 4: 5' CCCGGATCCTCATGCAGCATAAT 3'

Bam H I

Os iniciadores acima, foram utilizados para amplificar os fragmentos desejados utilizando-se como molde, o vetor pUC18 PROMOTOR (1700 pares de bases). Nas reações de amplificação, foram utilizados $1 \mu \mathrm{g}$ de DNA molde, 5,0 $\mu \mathrm{L}$ de tampão de PCR (10X concentrado), $2 \mu \mathrm{L}$ de cloreto de magnésio (50 mM), $1 \mu \mathrm{L}$ de um mix de dNTPs (10mM), 30 picomoles de cada iniciador específico e 0,5 unidades de DNA polimerase. O programa utilizado no termociclador foi o mesmo descrito no item 3.1.21.1. Esses fragmentos foram purificados do gel de agarose para serem utilizados nas etapas subsequentes.

Para as reações de restriçôes os fragmentos GUS 1, GUS 2, GUS 3, GUS 4 e o vetor binário pCAMBIA $1281 \mathrm{Z}$ foram digeridos com as enzimas $\mathrm{BamHI}$ e Ncol. As reações de ligação efetuadas foram as mesmas que as descritas anteriormente e seus produtos utilizados nos procedimentos de 
transformação de $A$. tumefaciens e, posteriormente de plantas, conforme metodologia detalhadamente descrita nos ítens 3.1.24 e 3.1.25.

\subsubsection{Expressão transiente e estável do gene uidA (GUS)}

Para os ensaios de expressão transiente em células epidérmicas de cebola e transformação estável de $N$. tabacum foram utilizadas as mesmas metodologias descritas anteriormente (3.1.23 e 3.1.24).

\subsubsection{Ensaio histoquímico da enzima ß-glucuronidase (GUS)}

Para verificar a atividade de GUS optou-se por utilizar o ensaio histoquímico que é um método qualitativo, baseado na clivagem do substrato 5bromo-4-cloro-3-indolil-beta-D-glucoronídeo (x-gluc) pela Beta-glucoronidase (GUS) (Jefferson et al., 1987). O produto desta reação, na presença de oxigênio, forma dímeros, resultando em um precipitado insolúvel de cor azul. Após o bombardeamento, os tecidos foram mergulhados em um tampão de reação composto de $100 \mathrm{mM}$ de $\mathrm{NaH}_{2} \mathrm{PO}_{4} \cdot \mathrm{H}_{2} \mathrm{O}, 0,5 \mathrm{mM}$ de $\mathrm{K}_{4} \mathrm{Fe}(\mathrm{CN})_{6} \cdot 3 \mathrm{H}_{2} \mathrm{O}, 10$ $\mathrm{mM}$ de $\mathrm{Na}_{2}$ EDTA. $2 \mathrm{H}_{2} \mathrm{O}, 0,1 \%$ de Triton X-100 e $1 \mathrm{mM}$ de X-Gluc e incubados no escuro a $37^{0} \mathrm{C}$ por 16 horas. Após este período, o tampão de reação foi substituído por etanol $70 \%$ cujo objetivo é interromper a reação. Após várias lavagens com água destilada, os tecidos foram observados em microscópio óptico.

\subsubsection{Ensaio fluorimétrico da enzima ß-glucuronidase (GUS)}

\subsubsection{Preparação do extrato celular}

Os extratos foram preparados através da maceração do material vegetal (100mg) por cerca de 1 minuto em $500 \mu \mathrm{L}$ de tampão de extração 
composto de $50 \mathrm{mM}$ de $\mathrm{NaH}_{2} \mathrm{PO}_{4}, 10 \mathrm{mM}$ de $\beta$-mercapetanol, $10 \mathrm{mM}$ de EDTA (pH 8,0), 0,1\% de Sódio Sarcosil, 0,1\% de Triton X-100 e 20\% de metanol. Em seguida, as amostras foram centrifugadas (para a sedimentação dos tecidos vegetais macerados) a $12000 \times \mathrm{xg}$ por 10 minutos a $4^{\circ} \mathrm{C}$. O sobrenadante foi transferido para novo tubo e mantido no gelo. $A$ atividade da $\beta$-glucuronidase foi determinada, misturando-se $50 \mu \mathrm{L}$ do extrato celular (sobrenadante) com 150 $\mu \mathrm{L}$ de tampão de reação (tampão de extração acrescido de $2 \mathrm{mM}$ de $\mathrm{MUG}$ ) pré aquecido $\left(37^{\circ} \mathrm{C}\right)$. As amostras (extrato celular + tampão de reação) foram incubadas à $37^{\circ} \mathrm{C}$ no escuro, a reação foi interrompida em diferentes intervalos de tempo através da adição de $20 \mu \mathrm{L}$ da mistura de reação à $1,98 \mathrm{~mL}$ de tampão de parada $\left(0,2 \mathrm{M}\right.$ de $\left.\mathrm{Na}_{2} \mathrm{CO}_{3}\right)$. Em seguida foi medida a fluorescência das amostras no fluorímetro DYNA QUANT ${ }^{T^{T}} 200$ devidamente calibrado (solução padrão de MU) seguindo todas as recomendações do fabricante (Hoefer). 


\section{RESULTADOS E DISCUSSÃO}

Uma das linhas de pesquisa do Laboratório de Biologia Molecular de Plantas (Departamento de Genética, ESALQ/USP) é estudar proteínas codificadas por um único gene que são direcionadas simultaneamente æ̀ mitocôndrias e cloroplastos de plantas (Silva-Filho, 2003).

Dentre os diferentes cDNAs codificando para proteínas da família AAA caracterizados em pimentão (Capsicun annuum), dois correspondiam à proteases do tipo $\mathrm{FtsH}$, notadamente bcp (hoje classificada como FtsH-p1) e cacp (hoje classificada como uma FtsH-p2). Porém, segundo informações de G. Holné (comunicação pessoal), apenas uma delas (a BCP) apresentava uma seqüência de direcionamento típica de proteínas direcionadas æ̀̀ mitocôndrias embora fossem encontradas associadas aos tilacóides no interior de cloroplastos. Sendo assim, a FtsH-p1 (BCP) tornourse um modelo interessante para estudar a possibilidade de um duplo direcionamento em importante família de proteínas.

\subsection{Análise das seqüências similares à FtsH em plantas superiores no Banco de Dados GenBanK ${ }^{1}$}

Seis proteases do tipo das FtsHs em plantas superiores foram identificadas no GenBanK:

\footnotetext{
${ }^{1}$ (http://www.ncbi.nlm.nih.gov/PubMed/)
} 
1- CaPfff= Capsicum annuum Pftf (cacp, AJ012165) - completa

2- NtPftf= Capsicum annuum Pftf (AF117339) - completa

3- AtPfff= Arabidopsis thaliana Pfff (3201633) - genômico

4- $\mathrm{CaFtsH}=$ Capsicum annuum FtsH (bcp, X90472) - parcial

5- NtFtsH= Nicotiana tabacum FtsH (AB017480) - completa

6- AtFtsH= Arabidopis thaliana FtsH (X99808) - completa

O alinhamento das seqüências mostrou que as proteases podiam ser agrupadas em dois grupos distintos: no primeiro, as seqüências mostravamse com alta similaridade à CACP (FtsH-p2) de pimentão e, no segundo, as seqüências agrupavam-se com a BCP (FtsH-p1). A fim de clonar o cDNA da $\mathrm{BCP}$ (FtsH-p1) em frutos de tomate, foram utilizadas as seqüências correspondentes æ̀ BCPs de tabaco (acesso AB017480) e de pimentão (acesso X90472), por se tratarem de espécies da mesma família (Solanaceae). Esse estudo comparativo indicou que as duas seqüências apresentavam uma alta similaridade em termos de aminoácidos ( $85 \%$ de identidade) e que eram bastante conservados, principalmente, em suas regiões centrais. Baseando-se nessa observação, dois oligonucleotídeos degenerados foram desenhados de forma a flanquearem essa seqüência bastante conservada (ver metodologia experimental).

Após o estabelecimento da técnica de extração de RNA e síntese de cDNA (RT-PCR) de frutos maduros de tomate, esses oligonucleotídeos degenerados foram utilizados na tentativa de encontrar essa região central de alta homologia nesta espécie (Lycopersicon esculentum Mill. cv. MicroTom). O resultado desta reação de PCR mostrou amplificação de um fragmento que correspondia a 1272 pares de bases que foi, imediatamente purificado, clonado e sequenciado conforme descrito na metodologia experimental. 


\subsection{Análise em Banco de Dados}

Após a reação de sequenciamento, a fim de verificar se a seqüência correspondente ao fragmento clonado (1272 pares de bases) correspondia realmente ao gene que codificava a FtsH (BCP ou FtsH-p1), a seqüência foi alinhada com as seqüências disponíveis e comparadas com àquelas depositadas no banco de dados GenBanK. A região amplificada (1272 pares de bases) apresentou $90 \%$ de identidade em termos de seqüência de nucleotídeos com a BCP (FtsH-p1) de pimentão e 85\% com o ortólogo de tabaco, indicando que o fragmento amplificado correspondia à seqüência FtsH esperada.

\subsection{Obtenção das extremidades 5' e 3' do gene FtsH-p1 via RACE (Rapid Amplification of cDNA Ends)}

Após a constatação de que $\mathrm{o}$ fragmento amplificado e sequenciado correspondia àregião central do gene FtsH-p1 (BCP) de tomate, a etapa seguinte consistiu em obter a seqüência completa do gene. Utilizando-se das técnicas 5' e 3'-RACE (metodologia experimental) foi possível amplificar dois fragmentos de aproximadamente 700 e 650 pares de bases, respectivamente. Estas seqüências mostraram alta similaridade com as seqüências dos ortólogos de fumo e pimentão.

\subsection{Obtenção do gene FtsH-p1 completo em uma única reação, utilizando uma DNA polimerase de alta fidelidade}

Um aspecto importante a ser considerado é que o cDNA completo da FtsH-p1 (BCP) de tomate, foi montado a partir de três fragmentos de DNA obtidos em diferentes momentos. Portanto, havia possibilidade de que 0 fragmento completo fosse uma quimera formada a partir de três fragmentos de 
diferentes origens (devido a presença de genes parálogos). Um outro aspecto que merece ser mencionado, é que em todas as etapas de clonagem e sublonagem foi utilizada uma Taq DNA polimerase comum, portanto passível de introdução de erros durante as reações de amplificação.

A fim de amplificar o cDNA completo em uma única reação (utilizando-se de uma polimerase de alta fidelidade), foram utilizados dois iniciadores cujas seqüências anelavam-se respectivamente às regiões 5'- e 3' não traduzidas do mRNA da FtsH-p1 de tomate. Foi amplificado um fragmento de 2272 nucleotídeos que, após as etapas de clonagem e sequenciamento, mostrourse corresponder ao cDNA completo da FtsH-p1 de tomate. No que se refere a seqüência de aminoácidos, ele apresenta $89 \%$ de identidade com a FtsH-p1 de pimentão e 86\% com a FtsH-p1 de tabaco (figura 11).

\subsection{Domínios estruturais}

Apesar das sequências de nucleotídeos e aminoácidos da FtsH-p1 de tomate apresentarem uma alta similaridade com as seqüências das FtsHsp1 de pimentão e tabaco, foi necessário identificar os principais motivos estruturais que são característicos de todas as proteínas que fazem parte desta família bem como prever o possível sítio de clivagem do peptídeo de trânsito.

A seqüência de aminoácidos codificada pelo cDNA da FtsH-p1 de tomate, revelou a presença de uma cópia do módulo AAA (seqüência de aproximadamente 250 aminoácidos que engloba tanto os motivos ATPásicos Walker $A$ e Walker $B$ quanto a seqüência $S R H$ ), duas regiões hidrofóbicas na região amino-terminal correspondentes aos domínios transmembrana e o motivo de ligação ao metal $\mathrm{Zn}^{+2}$ na região carboxi-terminal (figura 13).

A localização sub-celular da FtsH-p1 de tomate baseada no programa Target-P (http://www.cbs.dtu.dk/services/TargetP/) (Emanuelsson et al., 2000), indicou tratar-se de uma proteína cloroplástica (figura 12). Esta observação está de acordo com trabalhos que mostram que ortólogos da FtsH 
p1 são localizados nos cloroplastos (Lindhal, 1996; Marbach et al., 2001, e Adam, 2001).

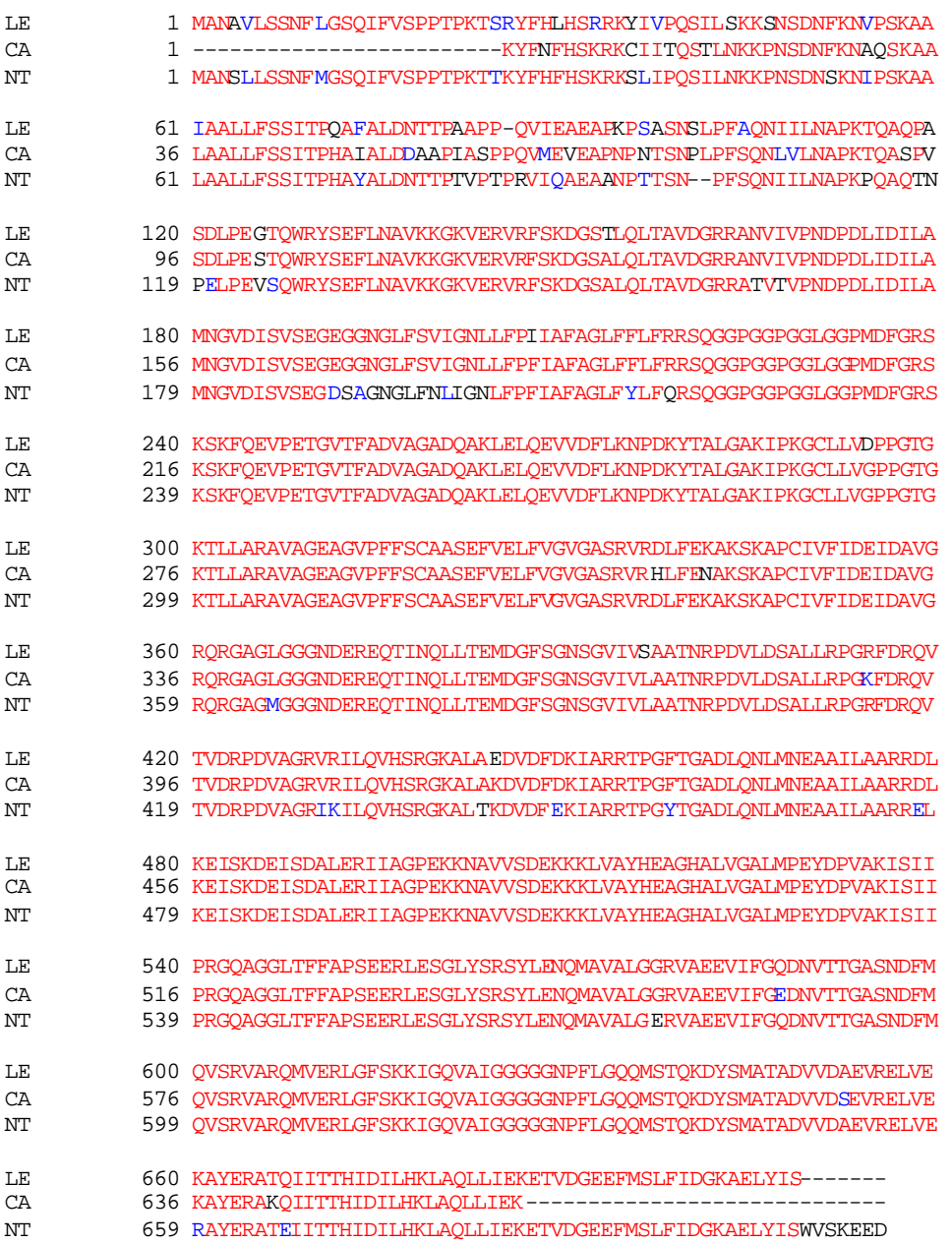

Figura 11 - Comparação das sequências de aminoácidos do produto do gene FtsH-p1 de Lycopersicon esculentum (LE), Capsicum annuum (CA) e Nicotiana tabacum (NT). Este alinhamento foi feito usandose o programa FASTA. Resíduos idênticos estão representados em vermelho, resíduos em azul indicam similaridade funcional. Os traços (-) indicam deleções e letras em preto indicam ausência de similaridade. 
O possível sítio de processamento estromal, baseado também no programa Target-P (http://www.cbs.dtu.dk/services/TargetP/) (Nielsen et al., 1997), foi localizado entre os aminoácidos 57 e 58 a partir da extremidade $\mathrm{N}$ terminal (figura 12 e 13). A presença do di-peptídeo MA no início da sequência, além de resíduos básicos (notadamente argininas) e frequência alta de serinas, indicam tratar-se de um típico peptídeo de trânsito presente em proteínas destinadas aos cloroplastos (figura 13) (Von Heijne et al., 1989).

\begin{tabular}{|c|c|c|c|c|}
\hline Seqüência & Plastidial & Mitocondrial & Secretório & Sítio Clivag. \\
\hline 129 aa & 0,834 & 0,149 & 0,011 & 57 \\
\hline
\end{tabular}

Figura 12 - Resultado proveniente do programa Target-P (os primeiros 129 aminoácidos foram usados na análise).

Nota: Score $=0,834$ (Plastidial) $=$ apresenta alta probabilidade de estar localizada nos plastídios e muito baixo score de localização mitocondrial. Sítio Clivagem=57 provável sítio de clivagem da seqüência de direcionamento pela peptidase estromal.

Entretanto, contrariando observações prévias (G. Houlné, comunicação pessoal), a FtsH-p1 de tomate não possui características de uma seqüência de direcionamento mitocondrial (Glaser et al., 1998).

Paralelamente, uma análise baseada no perfil filogenético e na predição da localização subcelular pelo programa Target $\mathrm{P}$ das $\mathrm{FtsHs}$ de procariontes e eucariontes estava sendo realizada no Laboratório de Biologia Molecular de Plantas da ESALQ/USP (Marbach et al., 2001). Baseados em sequências depositadas no GenBanK e junto ao projeto SUCEST da FAPESP, os autores revelaram, que além da existência de genes que codificavam proteínas plastidiais (FtsH-p1, FtsH-p2 e FtsH-p3) existiam também genes que codificavam para FtsHs mitocondriais. (Marbach et al., 2001) 

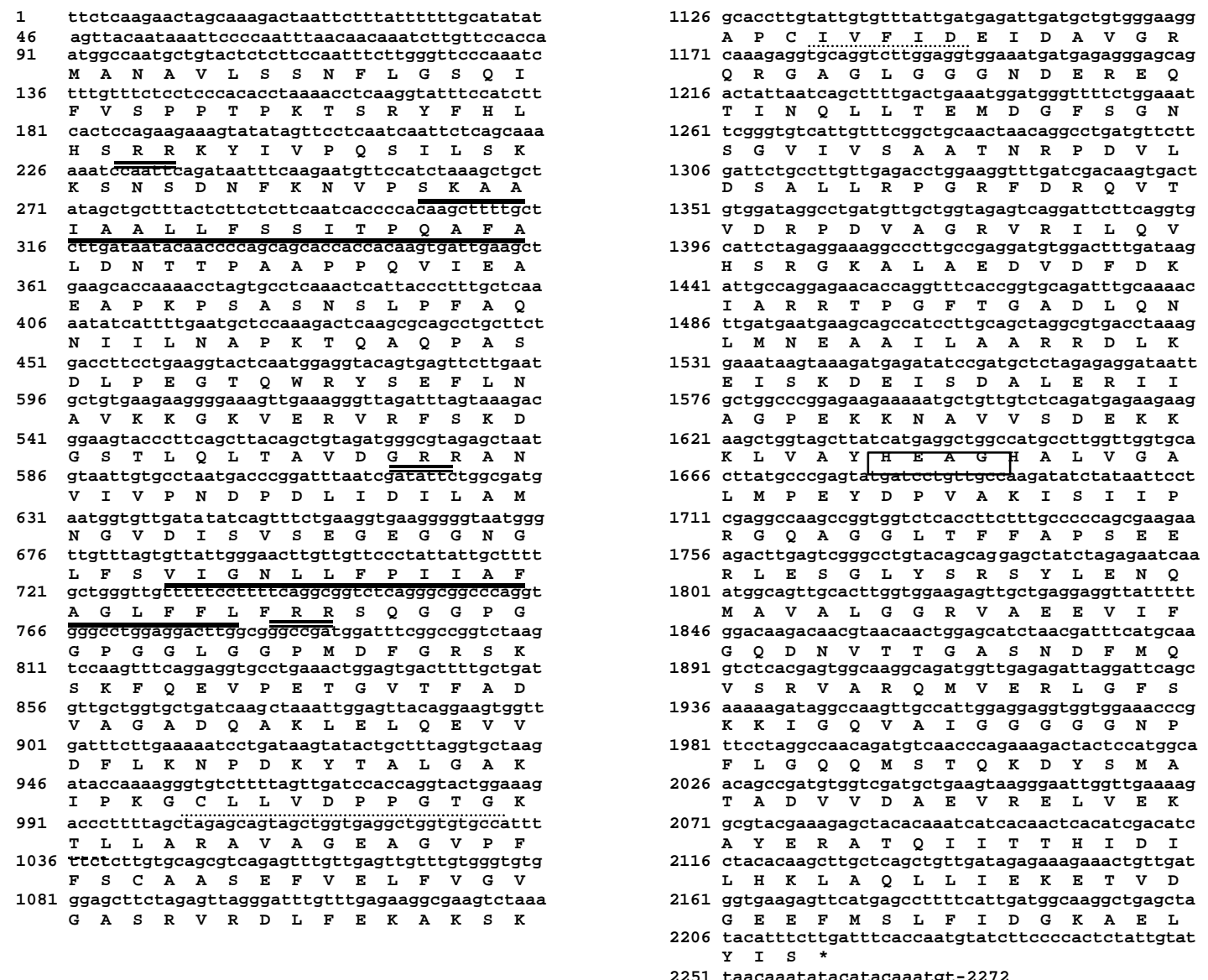

Figura 13 - Sequência de nucleotídeos e de aminoácidos da FtsH-p1 de tomate (Lycopersicon esculentum Mill. cv. MicroTom) deduzidas após as etapas de clonagem e subclonagem. Linhas simples $=$ indicam os possíveis domínios hidrofóbicos. Linhas tracejadas = motivos de ligação ao ATP. Linha dupla = regiões onde se localizam as duplas argininas $(\mathrm{RR})$. Seta vertical = possível sítio de processamento estromal. A caixa mostra o domínio de ligação ao metal $\mathrm{Zn}^{+2}$. 
Essas observações reforçaram os dados obtidos pelo presente trabalho e indicaram que a FtsH-p1 de tomate, provavelmente, não seria direcionada simultaneamente à mitocôndrias e cloroplastos, conforme sugestões iniciais (Guy Houlné, comunicação pessoal). Estas observações foram posteriormente comprovadas experimentalmente em ensaios de expressão transiente em células epidérmicas de cebola que expressavam proteínas de fusão baseadas na sequência de direcionamento da FtsH-p1 de tomate e a proteína fluorescente GFP (veja abaixo).

Em função destas observações, o objetivo inicial do projeto foi modificado. Desta forma, algumas alterações foram incorporadas ao trabalho de modo a explorar outros aspectos relacionados à $\mathrm{FtsH}-\mathrm{p} 1$ de tomate. $\mathrm{O}$ direcionamento da proteína FtsH (p1 e p2) no interior dos cloroplastos é um processo muito pouco conhecido. Em um trabalho relativamente recente, Summer e colaboradores (2000), sugeriram que a região responsável pela localização da proteína Pftf de pimentão (um ortólogo à FtsH-p2 de tabaco ou CaCP de pimentão) era determinada pela sua região $\mathrm{N}$-terminal, mais especificamente seu primeiro domínio hidrofóbico. Para verificar se a FtsH-p1 de tomate apresentava o mesmo padrão de direcionamento, foram realizadas algumas construções gênicas envolvendo fragmentos de diferentes tamanhos da região N-terminal do gene que codifica a FtsH-p1 de tomate e o gene repórter que codifica para a proteína GFP ("green fluorescent protein") todas dirigidas por um promotor de expressão constitutiva em plantas (35S).

A figura 14, mostra que a primeira construção (35S-TP-GFP) compreendeu apenas o peptídeo de trânsito da FtsH-p1 (deduzido a partir do programa de predição de seqüência Target-P) fusionado à proteína GFP. A segunda construção (35S-TP-H1-GFP) foi formada pelo peptídeo de trânsito mais a região que codifica o primeiro domínio hidrofóbico $(\mathrm{H} 1)$ fusionado à proteína GFP. A terceira construção (35S-TP-H1-Loop-GFP), incluiu o peptídeo de trânsito mais a primeira região hidrofóbica seguida da região hidrofílica (loop) que antecede a segunda região hidrofóbica $(\mathrm{H} 2)$. Finalmente, o último gene 
quimérico (35S-TP-H1-Loop-H2-GFP) foi formado pelo peptídeo de trânsito mais a alça hidrofílica, a região H2 e 11 aminoácidos da proteína madura da FtsH-p1.

a)

TP I loop II

FtsH

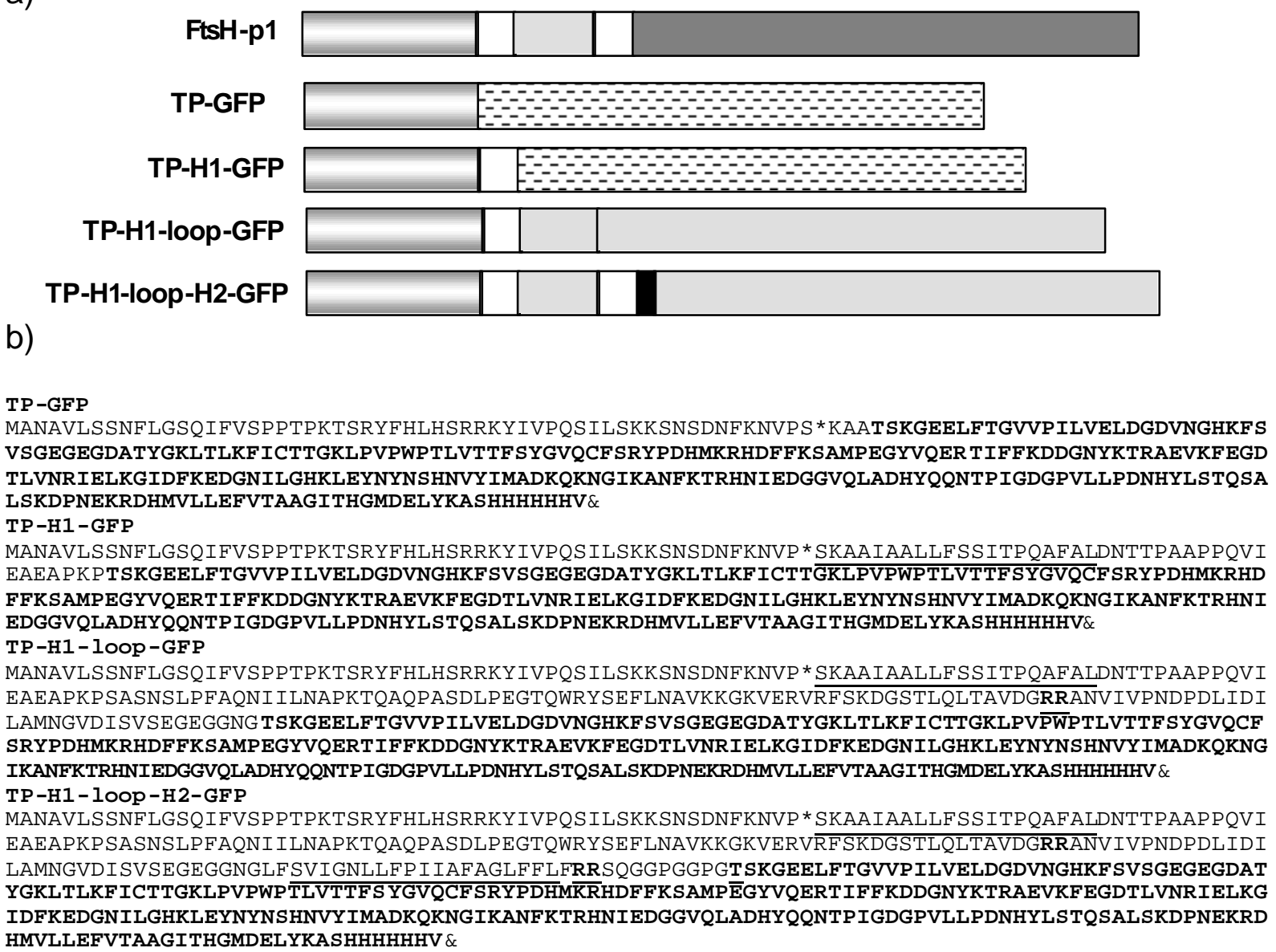

Figura 14 - a) Esquema representativo das construções gênicas, conforme detalhado na metodologia experimental e resultados e discussão. b) Seqüência de aminoácidos provenientes das construções gênicas. Em negrito está representada a seqüência da GFP. Grifado = domínios hidrofóbicos. 


\subsection{Localização subcelular da FtsH-p1 in vivo}

A localização subcelular da FtsH-p1 de tomate foi determinada a partir da expressão transiente da construção 35S-TP-GFP em células de cebola. Como controles, foram utilizados os vetores pCAMBIA 35S-GFP (expressa a GFP no citosol das células), o RecA-GFP (expressa a GFP apenas nos cloroplastos) (Köhler et al., 1997), a construção $\beta$-GFP que expressa a GFP na matriz mitocondrial (Duby et al., 2001) e a construção SYCO-GFP (que expressa a GFP em ambas as organelas) (Peeters et al., 2001) (Figura 15).

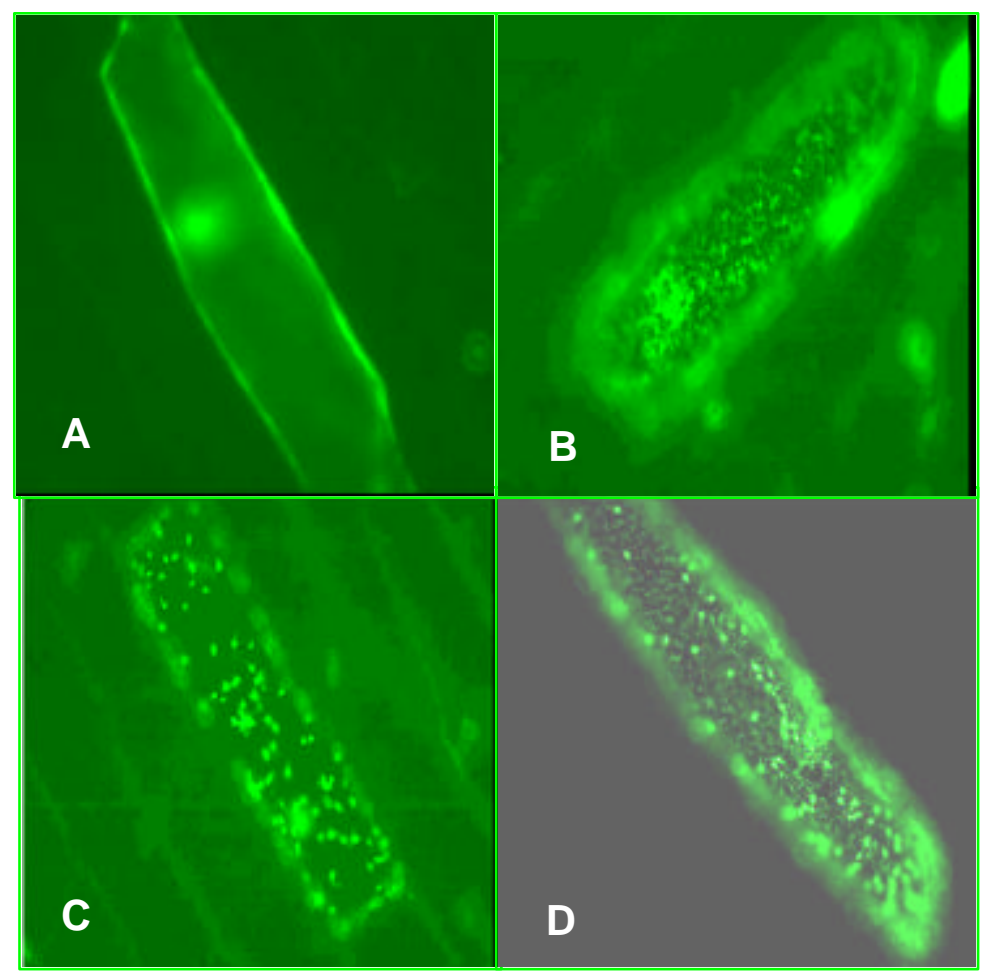

Figura 15 - Fotos tiradas em microscópio de fluorescência no qual células epidérmicas de cebola expressam a GFP em diferentes compartimentos subcelulares. Em A, observa-se o perfil ou características das células que expressam a GFP no citosol (construção 35S-GFP). Em B, as células expressam a GFP no interior das mitocôndrias $\beta$ GFP). Em C, a GFP é expressa apenas nos plastídeos (RecA-GFP). Em D, duplodirecionamento da GFP para cloroplastos e mitocôndrias (SYCO-GFP). 
De acordo com o perfil filogenético e a predição de sua localização subcelular, observa-se que todas as proteínas de fusão (TP-GFP, TP-H1-GFP, TP-H1-loop-GFP e TP-H1-loop-H2-GFP) localizam-se especificamente nos plastídeos (figura 16).

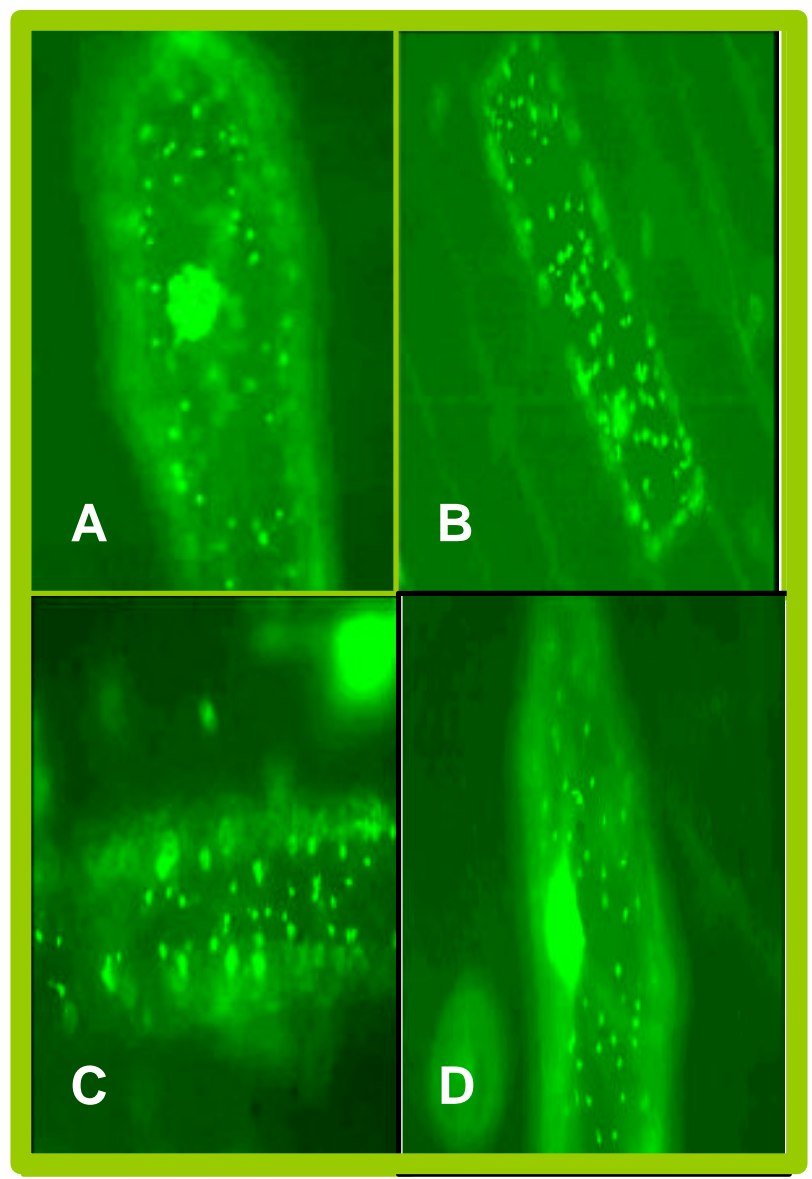

Figura 16 - Fotos tiradas em microscópio de fluorescência no qual células epidérmicas de cebola expressam a GFP provenientes das construções gênicas. A, B, C e D: construções TP-GFP, TP-H1GFP, TP-H1-LOOP-GFP e TP-H1-LOOP-H2-GFP, respectivamente. 
Portanto, a hipótese de que a FtsH-p1 pudesse ser transportada à mitocôndrias simultaneamente aos cloroplastos, mostrou-se incorreta.

A fim de estudar a translocação da FtsH-p1 æ̀ membranas dos tilacóides, as construções envolvendo a região N-terminal da FtsH-p1 fusionadas à GFP, foram expressas de forma estável em plantas de tabaco $(N$. tabacum), utilizando-se o sistema $A$. tumefaciens.

Após as etapas de transformação genética via $A$. tumefaciens, várias plântulas (provenientes das diferentes construções gênicas) foram regeneradas em meio contendo um agente seletivo (antibiótico higromicina). Posteriormente, as plântulas enraizadas em meio seletivo foram analisadas quanto à presença do T-DNA via PCR. Em seguida, as plantas foram transferidas para vasos e aclimatadas em casa de vegetação, juntamente com plantas selvagens (WT) que serviram de controle.

\subsection{Expressão do transgene}

A presença do T-DNA não necessariamente indica que o gene de interesse introduzido seja expresso. O chamado efeito de posição, relacionado ao locus no qual o gene foi inserido, faz com que variações expressivas na expressão de um gene sejam observadas, inclusive o total silenciamento do gene de interesse (Mlynarova et al., 1996). Assim sendo, metodologias que monitorem a expressão do gene inserido são necessárias à caracterização molecular das plantas. A confirmação da transcrição dos genes quiméricos nas plantas transgênicas foi observada a partir de experimentos utilizando-se a metodologia do RT-PCR (Reverse Transcriptase-Polymerase Chain Reaction). Os resultados mostraram a presença de transcritos específicos à todas as construções utilizadas nos diferentes transformantes independentes, enquanto não houve detecção de transcritos nas plantas não transformadas (dados não mostrados). Plantas transgênicas expressando os diferentes cassetes foram 
avaliadas quanto à presença da proteína GFP via Western Blot utilizando-se o anticorpo anti-GFP (figura 17).

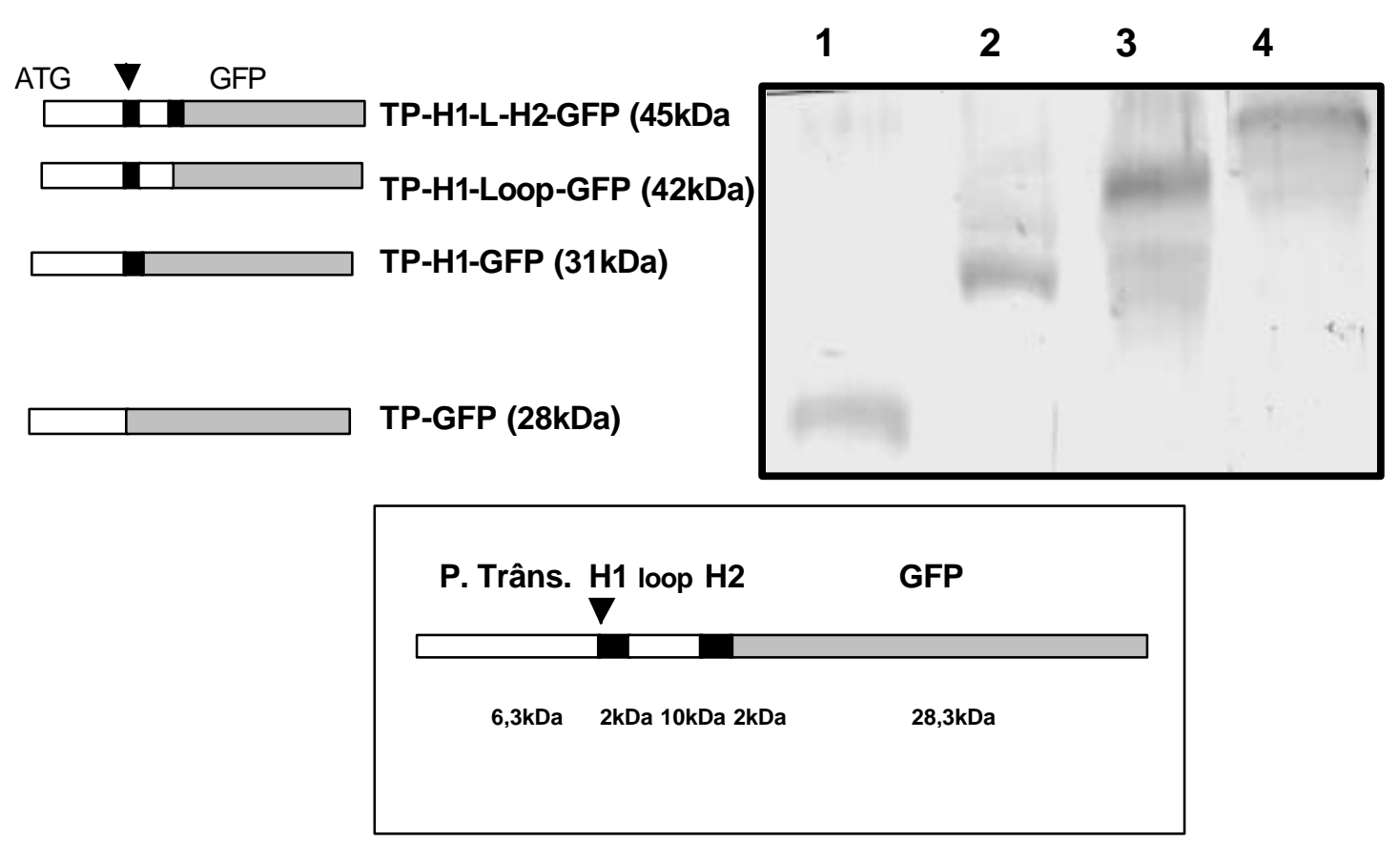

Figura 17 - Figura mostrando a imunodetecção (Western Blot usando anti-GFP) no extrato proteico total de plantas. Os pesos moleculares (kDa) referem-se aos obtidos após o primeiro processamento (o sítio de processamento esta sinalizado com uma seta). Também estão representados os peso moleculares (aproximados) de todos os domínios da proteína FtsH-p1.

Os resultados mostraram que 0 anticorpo reconheceu especificamente a GFP quando fusionada ⿱亠े regiões $\mathrm{N}$-terminais da FtsH-p1 de tomate. Um resultado interessante foi observado em relação ao processamento das proteínas de fusão. De acordo com dados prévios, o processamento de proteínas destinadas aos tilacóides ocorre em duas fases distintas. Primeiramente, o peptídeo de trânsito é removido por uma protease estromal, 
enquanto que um segundo processamento ocorre na membrana dos tilacóides (Robinson et al., 2000). Os dados obtidos com o Western Blot a partir de um extrato celular total mostram a ocorrência de apenas um único processamento (figura 17). Curiosamente, Summer e colaboradores (2000) mostraram que após a importação da proteína Pftf de pimentão (ortólogo da FtsH-p2 de tabaco) nos cloroplastos, a região imediatamente posterior a primeira região hidrofóbica (supostamente envolvida na exportação da FtsH-p2 para as membranas dos tilacóides), sofria uma segunda clivagem por uma peptidase tilacoidal liberando a proteína na membrana desprovido do primeiro domínio hidrofóbico. Este segundo processamento não ocorre com as proteínas quiméricas sugerindo que a GFP não é inserida na membrana do tilacóide. Este modelo indicaria que o segundo processamento ocorreria após a integração da proteína na membrana (interações hidrofóbicas com a membrana). A idéia de que o reconhecimento e processamento da FtsH ocorra após sua inserção reforça a idéia de que a proteína seja primeiramente inserida antes de efetuar sua translocação (Brüser \& Sanders, 2003). Uma outra possibilidade é que a FtsH-p1 de tomate apresente um mecanismo diferente da FtsH-p2 no que diz respeito ao direcionamento para as membranas dos tilacóides, isto é, após o processo de exportação, a FtsH-p1 não sofreria a segunda clivagem pela peptidase tilacoidal ficando dessa forma ancorada nas membranas com seus dois domínios hidrofóbicos. Portanto, a determinação da localização das proteínas quiméricas dentro dos cloroplastos tornou-se essencial para o entendimento de suas propriedades de direcionamento.

\subsection{Localização intra-plastidial das proteínas de fusão}

A partir da obtenção de cloroplastos intactos isolados via gradientes de Percoll, foram obtidas duas frações subsequentes: a fração estromal (solúvel) e uma fração contendo os tilacóides. A qualidade do fracionamento intra-cloroplastidial foi verificada a partir da utilização de 
anticorpos específicos dirigidos contra uma proteína estromal SRP54 (Mori et al., 1999) e uma proteína da membrana dos tilacóides, a LHCP (Summer \& Cline, 1999) (Figura 18). Como esperado, a GFP não foi detectada nas plantas não transformadas (WT).

Os resultados do Western Blot nas plantas transgênicas confirmam, primeiramente, as observações com a expressão transiente das proteínas quiméricas no qual a GFP foi direcionada aos plastídeos. Entretanto, o resultado mais importante e inesperado mostra que nenhuma das proteínas quiméricas em estudo foi direcionada aos tilacóides, principalmente, a proteína TP-H1-loop-H2-GFP, que possui os domínios hidrofóbicos capazes de reter a FtsH-p1 nos tilacóides.

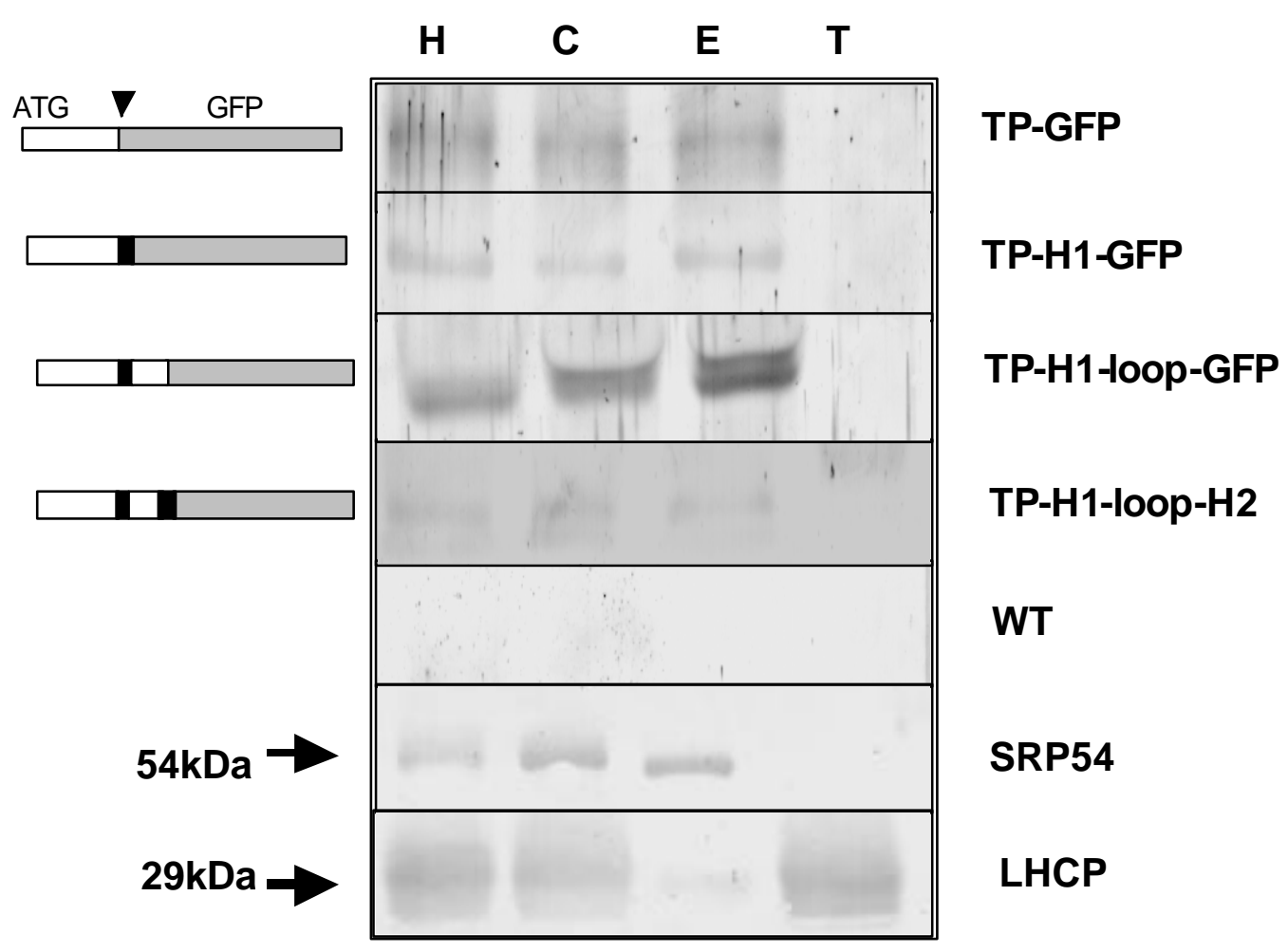

Figura 18 - Figura mostrando a imunodetecção (Western Blot) usando anti-GFP nas seguintes frações subcelulares: $H=$ homogenizado total, $\mathrm{C}=$ fração enriquecida de cloroplastos, E=fração solúvel do cloroplasto (estroma) e T=fração enriquecida de tilacóides. 
Estas observações trazem reflexões importantes sobre 0 mecanismo de transporte da FtsH-p1 de tomate àmembrana dos tilacóides. Um primeiro aspecto a ser analisado é o tipo de mecanismo envolvido, ou seja, qual o tipo de sistema de exportação utilizado. A caracterização de uma proteína da família das FtsHs-p2 em pimentão (Pftf) mostrou que esta protease segue a via Tat-dependente (presença do motivo RRXFLK no peptídeo de trânsito (Summer et al., 2000). Uma observação intrigante é que alguns membros da família da FtsHs de plantas que são direcionados aos tilacóides não apresentam este motivo conservado que está presente em praticamente todas as proteínas que seguem a via Tat, tanto em bactérias quanto em plantas (Dalbey \& Robinson, 1999). Curiosamente, ortólogos da FtsH-p1 de tomate não apresentam este motivo em sua região N-terminal (figura 19). Portanto, alguns pontos importantes merecem ser objeto de uma discussão mais aprofundada. Será que este grupo de FtsHs, incluindo a FtsH-p1 de tomate, que não apresenta o motivo RRXFLK, utiliza parte da via Tat que seria independente do motivo baseado na dupla arginina? Se for o caso, estas observações podem ampliar significativamente os substratos Tat-dependentes. Alguns trabalhos tem mostrado a não essencialidade do duplo $\mathrm{RR}$ na região aminoteminal, pois pequenas variações neste motivo mostraram não interferir na translocação da via Tat. Entretanto, as alterações foram sempre substituindo as argininas por lisinas, ou seja, mesmo grupo funcional (Maduenõ et al., 1994; Summer et al., 1999; Molik et al., 2001). Também é possível supor que a presença de outras argininas na sequência poderiam desempenhar o papel do motivo RRXFLK. Isto indicaria que há uma certa flexibilidade na localização destas duplas-argininas na região N-terminal das proteínas que seguem a via Tat. Interessantemente, ao analisar-se a sequência da FtsH-p1 de tomate, outras três duplas-argininas são encontradas (figura 13). A primeira dupla RR é encontrada dentro do peptídeo de trânsito, portanto provavelmente não deve ser considerada devido ao fato de ser eliminada por ocasião do processamento da proteína pela protease estromal. A segunda é encontrada dentro da região hidrofílica entre os dois segmentos 
hidrofóbicos ( $\mathrm{H} 1$ e $\mathrm{H} 2)$. Entretanto, os aminoácidos adjacentes não seguem o padrão observado no motivo RRXFLK. Finalmente, uma terceira dupla RR é encontrada logo após a hélice hidrofóbica H2. Neste caso, foi demonstrado experimentalmente no caso da Pftf que esta região (também presente nesta proteína) não é um elemento essencial à via Tat. Entretanto, a possibilidade de uma variação quanto à localização do motivo RRXFLK parece ser remota uma vez que o principal determinante da via Tat é a presença do motivo RR imediatamente antes de uma região hidrofóbica (Robinson et al., 2000). Uma outra alternativa interessante é que membros de uma mesma família (no caso as FtsHs) possam utilizar sistemas de exportação distintos. Estas especulações podem ser testadas experimentalmente e serão objeto de estudo posterior.

Uma crítica que pode ser feita ao trabalho é que a proteína repórter utilizada, no caso a GFP, pode não funcionar como um modelo para estudos da via Tat. Entretanto, em um trabalho recente, Marques e colaboradores (2003) mostraram que a GFP é eficientemente translocada aos tilacóides pela via Tat, embora não o seja quando fusionada a peptídeos de trânsito que utilizam a via Sec. Isto porque a via Tat permite a translocação de proteínas na sua estrutura terciária, enquanto que na via Sec isto não é possível (Robinson et al., 2000). A GFP, ao chegar ao estroma, adquire sua estrutura terciária e é capaz de emitir fluorescência (Marques et al., 2003), sendo portanto, um bom modelo para estudo do sistema Tat. 
CAPAN-CAA0 9935 NICTA-AAD 17230 ARATH-AAO41866 ARATH-AAF 65925 CAPAN-CAA62084 NICTA-BAA33755 MEDSA-AAK15322 ARATH-AAM 67567 ARATH-AAM83215

CAPAN-CAA0 9935 NICTA-AAD 17230 ARATH-AAO41866 ARATH-AAF 65925 CAPAN-CAA62084 NICTA-BAA33755 MEDSA-AAK15322 ARATH-AAM 67567 ARATH-AAM83215

CAPAN-CAA0 9935 NICTA-AAD17230 ARATH-AAO41866 ARATH-AAF 65925 CAPAN-CAA62084 NICTA-BAA33755 MEDSA-AAK15322 ARATH-AAM 67567 ARATH-AAM83215

CAPAN-CAA0 9935 NICTA-AAD17230 ARATH-AAO41866 ARATH-AAF 65925 CAPAN-CAA62084 NICTA BAA33755 MEDSA-AAK15322 ARATH-AAM 67567 ARATH-AAM83215

CAPAN-CAA09935 NICTA-AAD 17230 ARATH-AAO41866 ARATH-AAF 65925 CAPAN-CAA62084 NICTA BAA33755 MEDSA-AAK15322 ARATH-AAM 67567 ARATH-AAM83215

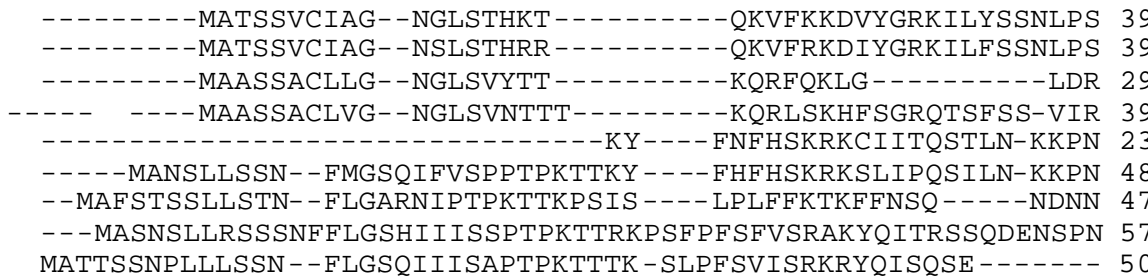

SGKT SRVVVKASLQ-QRPDEGRRGFLKLLLGNVGLGAPALLGNGKAYADEQG-------- 90 SSKTSRIAVKASLQ-QRPDEGRRGFLKLLLGNVGLGVPALLGDGKAYADEQG-------- 90 TSKVT--VVKASLD-EKKHEGRRGFFKLLLGNA-AAGVGLLAS GNANADEQGQ------ - 78 TSKVN--VVKASLDGKKKQEGRRDFLKILLGN---AGVGLVAS GKANADEQG-------- 86 SDNFKNAQSKAALAALLF SS ITP HA IALDDAAP IASP PQVMEVEAPNPNTSNP LPF SQNL 83 SDNSKNIPSKAALAALLFSSITPHAYALDNTTPTVP TPRVIQAEAANPTTSN--PFSQNI 106 NNNSEP IKSAAVSALILSSMFTPAALAADNLPPP P P PVLEAQPNQLNPANSTS-PFSQNI 106 GKP NSP F S SQVALAA I LLSS I SS SP LALAVVDEPASP SVVIESQAVKP S TP SP -LF IQNE 116 -KLMKSLP SQAALAALLFS--SSSPQALAVNEPVQPPAPTITAEAQSPNLST---FGQNV 104

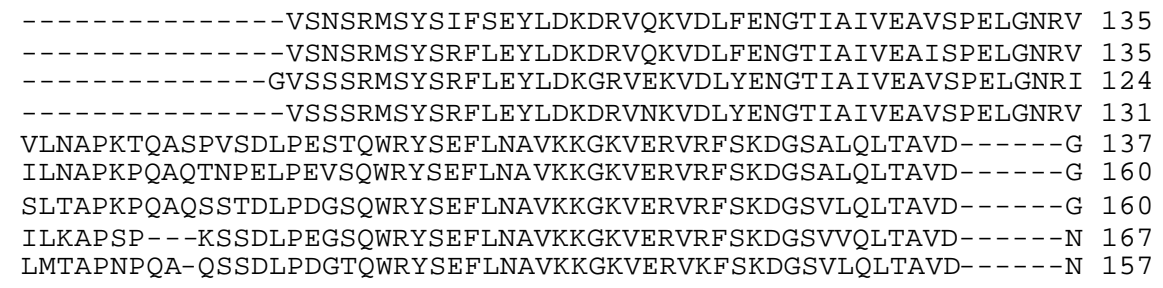

QRVRVQLPGLSQELLQKFREKNIDFAAHNAQEDSGSLIFNLIGNLAFPLILIGGLFLLSRR 196 QRVRVQLP GLSQELLQKLREKNIDFAAHNAQED SGSF LFNLIGNLAFPLILIGGLFLLSRR 196 ORVRVOLPGLSOELLOKLRAKNIDFAAHNAOEDOGSP I LNLIGNLAFPVILIGGLFLLSRR 185 ERVRVQLPGLSQELLQKLRAKN IDFAAHNAQED QGSVLFNLIGNLAFPALLIGGLFLLSRR 192 RRANVIVP-NDPDLIDI LAMNGVDISVS-EGE-GGNGLF SVIGNLLFPFIAFAGLFF LFRR 195 RRATVTVP-NDPDLIDI LAMNGVDISVS-EGDSAGNGLFNLIGN-LFPFIAFAGLFYLFOR 218 RRANVIVP-NDPDLIDI LAMNGVDISVS-EGE-QGNGLFSFVGSLLLPFLAFAGLFLIFRR 218 RRASVIVP-NDPDLIDILAMNGVDISVS-EGESSGNDLFTVIGNLIFPLLAFGGLFLLFRR 226 RRATVIVP-NDPDLIDILAMNGVDISVS-EGEG-GNGLFDF I GNLLFP LLAFGGLFYLFRG 215

4

SNGG-MGGP GGP GNP LAFGQSKAKFQMEPNTGVT 229 SPGG-MGGP GGP GNP LAFGQSKAKFQMEPNTGVT 229 SSGG-MGGP GGP GFP LQIGQSKAKFOMEPNTGVT 218 SGGG-MGGP GGP GNP LQFGQSKAKFQMEPNTGVT 225 SQGG-PGGP GGLGGPMDFGRSKSKFQEVPETGVT 228 SQGG-PGGPGGLGGPMDFGRSKSKFQEVPETGVT 251 GQGG-PGGP GGLGGPMDFGRSKSKFQEVPETGVT 251 AQGGP GGGP GGLGGPMDFGRSKSKFQEVPETGVS 260 GQGG-AGGPGGLGGPMDFGRSKSKFQEVPETGVT 248

Figura 19 - Alinhamento das seqüências provenientes dos dois grupos de FtsHs. Os acessos representados em rosa representam as FtsHs-p2 e os acessos em negrito, as FtsHs-p1. Em vermelho, estão representdos os RRs (ver texto). A seta está indicando o RR que acredita-se ser responsável pela exportação (via Tat) das FtsHsp1. Em azul, as regiões hidrofóbicas. 
Os resultados obtidos neste trabalho vão contra, de uma certa maneira, ao modelo atual de inserção de proteínas na membrana pela via Tat. Este modelo estabelece que para a formação do translocon, a maquinaria Tat deve reconhecer a região hidrofóbica juntamente com o RR. Assim, aparentemente, a inserção da FtsH-p1 de tomate nas membranas dos tilacóides além de ser determinada pelos motivos estruturais presente em sua região amino-terminal, é também dependente da informação presente na proteína madura necessária para a interação com as membranas ou mesmo com um fator desconhecido. Ou seja, a inserção da proteína na membrana depende de informação presente na proteína madura, seja de forma direta interagindo com proteínas e lipídios de membrana, seja via indireta a partir de substratos ainda não identificados. Para confirmar estas observações, seria importante realizar uma construção na qual a sequência completa da FtsH-p1 de tomate seria fusionada àGFP. Este controle é extremamente importante para verificar se realmente a GFP ficaria associada àmembrana dos tilacóides.

\subsection{Clonagem da região promotora do gene FtsH-p1, utilizando a técnica PCR-TAIL}

Apesar do controle da expressão gênica e a degradação de proteínas regulatórias via proteases celulares estar bem documentado em bactérias, pouco se sabe sobre os mecanismos que regulam o processo em plantas, principalmente no que se refere aos mecanismos de regulação dos genes que codificam para as FtsHs. A abordagem que foi explorada, foi clonar a região promotora do gene $\mathrm{FtsH}-\mathrm{p} 1$ e fusioná-la ao gene repórter uidA (GUS) e estudar sua regulação em diferentes tecidos (expressão espacial), em diferentes estádios de desenvolvimento (expressão temporal) e em resposta a estímulos ambientais ou situações de estresse.

Para clonar a região 5' flanqueadora do gene FtsH-p1, optou-se por utilizar uma técnica denominada PCR-TAIL (thermal asymmetric interlaced 
PCR), desenvolvida por Liu \& Whittier em 1995. Ela consiste em utilizar oligonucleotídeos específicos em combinação com iniciadores curtos, degenerados e de seqüências arbitrárias.

Após inúmeras tentativas, conseguiu-se amplificar um fragmento de aproximadamente 650 pares de bases. Para realmente comprovar que esse fragmento correspondia à região promotora do gene $\mathrm{FtsH}-\mathrm{p} 1$ de tomate e não uma banda inespecífica, ele foi clonado e sequenciado. Para se certificar que a seqüência proveniente do sequenciamento correspondia à uma região promotora e continha motivos regulatórios específicos, utilizou-se o programa disponível na internet e que se destina especificamente para esse propósito. 0 programa forneceu como dados de saída dezenas de motivos, dos quais alguns estão representados na figura 20.

XXXXXXXGAGTGAAGATGGAAATACCTTGTGTTTCGGTAGGGAGGAAAAACATTTGCTAGTC ATGCAAACGTTAACAACAAATATAACCCTTGGGAAACTATCGTTTAATATTTGCTTAACTCAC AAAATTTAGTTTATTGTATGATACTTTCTCACAAGATTTTAAAGCGTGGCTAAAAAAGGTCCA CAATTCATCCAACAGAAAAAAGAAGGATCATTTTGAAAATTTCACCAACACAACACAGAGAC CTTCCCTTGGGTTGGGCCACATTCTTATGACAAGATGAATGATTTAATGGGCCTTGTACCCA CTCTACAGCATCCTTAGGCCCAATTCTCTGTGCTATTGAGCAGTGAATACAAGCTTGAGCCT TCATTCTTTGTTITGATAGTCCGATTGAATTTAAATTCACGTACTAGAGAGATAACTCGACA TCAATGACTCAGCACGAGAATAAGAATGTATAGTAAATATT...

TATA

BOX

TGCGGATTTCCATTTTTTTCCCACATAAATATCAATCAAAGGTGACTGGATAA

CATTCTGACACGTAGAAGCAACCCAAACCAACATCCAAATCTATGGCTTCTATTCAATTTCTC AAGAACTAGCAAAGACTAATTCTTATITITGCATATATAGTTACAATAAATTCCCCAATTA ACAACAAATCTTGTTCCACCAATG...FtsH

Figura 20 - Seqüência de nucleotídeos referente àregião promotora do gene da FtsH-p1 de tomate analisada pelo programa PLACE. No interior das caixas podemos observar o possível início do transcrito $(+1)$ e a TATA BOX. Em letras coloridas estão marcados os possíveis motivos regulatórios (GATA=luz, CAAT BOX, TाTTC=giberelina, etc). 
Vários motivos, principalmente os relacionados ao core promoter foram encontrados e estão de acordo com os dados disponíveis na literatura (a possível região TATA-BOX encontra-se situada a aproximadamente 30 pares de base do início do transcrito (inferida através da técnica 5' RACE). Porém, os dados mais conclusivos referem-se aos motivos que aparentemente são reconhecidos por fatores responsíveis à luz. Esse dado confere com os disponíveis na literatura que mostram que as FtsHs são realmente reguladas por esse fator ambiental (Ivashuta et al., 2002). Entretanto, baseando-se em artigos que envolvem experimentos com regiões promotoras, optou-se por ampliar a região disponível de forma a tentar melhor representar os principais motivos regulatórios. Após algumas tentativas, obteve-se um fragmento de aproximadamente 1100 pares de bases que após o sequenciamento, mostrouse representar a região 5' do gene da FtsH-p1. Dessa forma, obteve-se um fragmento de aproximadamente $1700(650+1100)$ pares de bases (dados não mostrados).

\subsection{Construções gênicas envolvendo a região promotora da FtsH-p1 e o gene uidA (GUS) para transformação de plantas}

Para caracterizar as regiões regulatórias do promotor, quatro construções gênicas a partir de deleções da extremidade 5' do promotor da FtsH-p1 fusionadas ao gene reporter uidA foram preparadas. Para isso foi utilizado o vetor pCambia 1281 Z (Roberts et al., 1997), no qual o gene gus está desprovido de região promotora. Todos os dados referentes as etapas de clonagem, bem como os oligos utilizados, estão descritos na metodologia experimental.

A construção GUS 1 abrange a sequência 5'-UTR (até a região do correspondente ao início do transcrito $(+1)$, sem entretanto abranger a possível região TATA-BOX. A construção (GUS 2), compreendeu um fragmento de aproximadamente 370 pares de bases que engloba a região TATA BOX mais 
uma sequência de nucleotídeos onde são identificados alguns motivos putativos regulados pela luz e giberelina. A terceira (GUS 3), corresponde àum fragmento de 650 pares de bases, e finalmente, a construção (GUS 4) compreende o fragmento de aproximadamente 1700 pares de bases obtido da fusão do primeiro fragmento $(650 \mathrm{pb})$ com o que foi gerado na segunda reação de PCR TAlL (1100 pb) (figura 21).

\begin{tabular}{|llllll|} 
AUX LUZ Outros LUZ & GIB TATA +1 & & ATG \\
\hline &
\end{tabular}

GUS 1

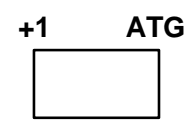

GUS 2
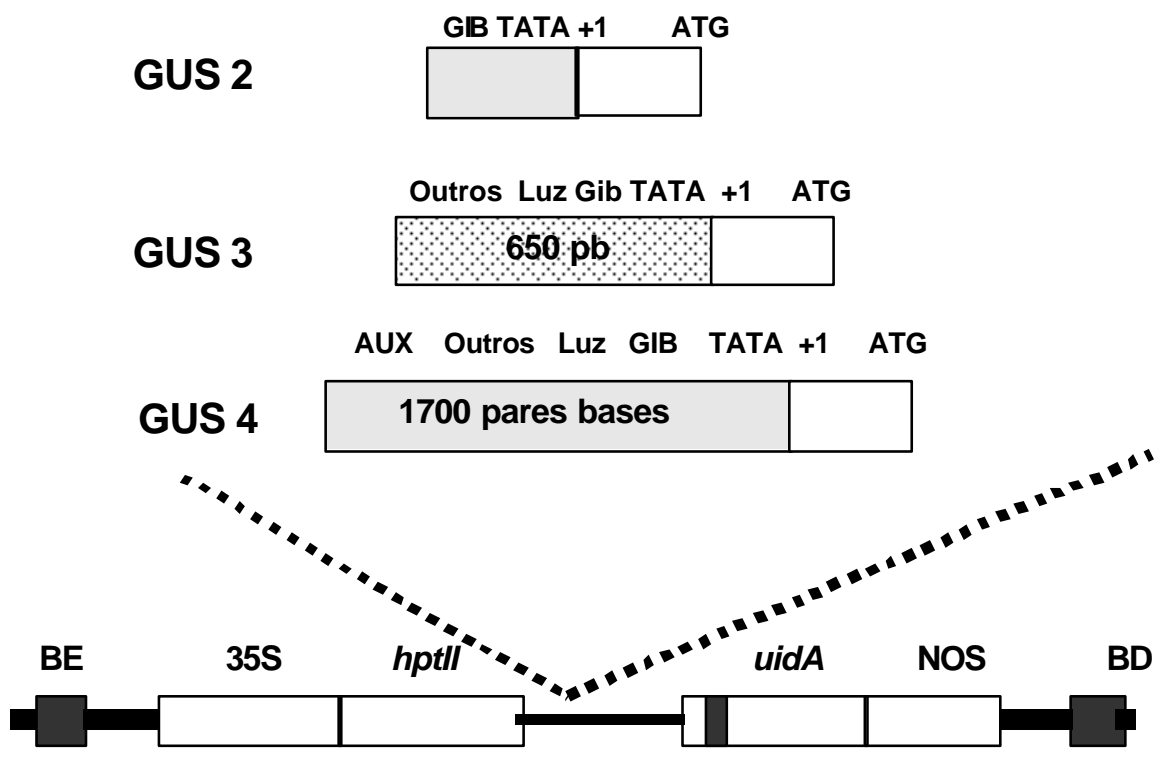

Figura 21 - Representação esquemática dos fragmentos amplificados e ulilizados na inserção no vetor de expressão pCAMBIA $1281 Z$. $\mathrm{BD}$ e $\mathrm{BE}$ representam as bordas direira e esquerda do T-DNA, respectivamente. 
A fim de verificar se a região clonada (1700 pares de bases) era capaz de dirigir a expressão do gene repórter uidA (GUS), foi realizado um ensaio de expressão transiente em células da epiderme de cebola com três diferentes vetores. Como controle positivo, utilizourse o vetor pCambia 1301, que contém o 35S-GUS como cassete de expressão em plantas. Como controle negativo, foi utilizado o vetor pCambia 1281Z, no qual o gene uidA não apresenta uma região regulatória, portanto, a proteína GUS não é expressa. $O$ vetor pCambia 1281Z+1700pb+GUS (construção GUS4), juntamente com as outras construções foram introduzidos nas células de cebola via método da biobalística. O teste histoquímico revelou que a região 5' do gene da FtsH-p1 de tomate contém elementos regulatórios que permitiram a expressão da proteína GUS em um sistema de expressão heterólogo (figura 22). Portanto, a região de 1700 pares de base clonada possui elementos regulatórios capazes de dirigir a expressão de um gene. Entretanto, é difícil determinar se todos os elementos regulatórios presentes na região promotora do gene da FtsH-p1 estão presentes, visto que enhancers podem estar localizados àmilhares de pares de bases a montante do ponto inicial da transcrição (Butler \& Kadonaga, 2002). A expressão obtida com o vetor 35S-GUS e a ausência de expressão com o vetor pCambia $1281 Z$ indicam que os dados obtidos com a construção GUS4 sejam resultado do promotor da FtsH-p1 e não de um artefato do experimento.

Após os resultados obtidos com a expressão transiente, o próximo passo consistiu em verificar a capacidade de regulação destas seqüências (construções) em um sistema estável de expressão. Em uma primeira etapa, optou-se por tentar transformar tanto plantas de tomate quanto de tabaco utilizando o sistema $A$. tumefaciens. Como a região regulatória recém clonada era proveniente de tomate (cultivar MicroTom), a idéia inicial era de utilizar um sistema de expressão baseado em seu contexto natural. Entretanto, as tentativas de transformação de tomate não apresentaram sucesso, pois o cv. MicroTom apresenta, segundo comunicação pessoal do Prof. Dr. Lazaro Peres, 
uma baixa capacidade de regeneração in vitro. Assim sendo, os trabalhos envolvendo a caracterização do promotor da FtsH-p1 foram efetuados em

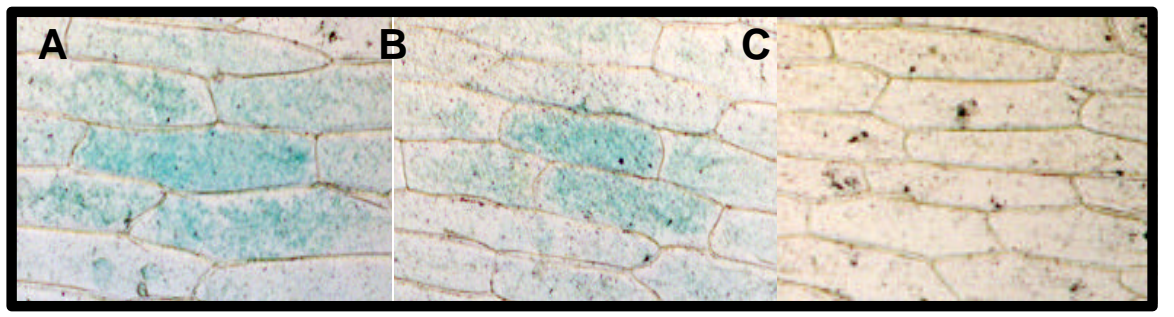

Figura 22 - Detecção da atividade de GUS pelo ensaio histoquímico. A e B: expressão transiente de GUS em células epidérmicas de cebola (aumento 4x) 16 horas após transformação com biobalística com os vetores pCambia1301 (35SGFP) e pCambia1281Z+Promogus4 e pCambia 1281Z, respectivamente.

tabaco, espécie que apresenta um sistema de transfomação já estabelecido no laboratório de Biologia Molecular de Plantas (ESALQ/USP) (Barata et al., 2000; Chabregas et al., 2001).

As etapas que envolveram transformação via $A$. tumefaciens, regeneração em meio contendo um agente seletivo (antibiótico higromicina) e transferência para vasos após o enraizamento das plântulas PCR positivas foram idênticas àquelas descritas na obtenção das plantas expressando a GFP. Após vários ciclos de autofecundação, sementes contendo o T-DNA em homozigose para todas as construções foram usadas na maioria dos experimentos que serão relatados a seguir. Em todos os experimentos, as sementes foram germinadas em meio MS normal e, posteriormente, transferidas para o meio contendo o componente objeto de estudo. 


\subsection{Regulação pela LUZ}

Como comentado anteriormente, vários motivos regulatórios (GATABOX=GATA; GT1=GRWAAW; IBOX=GATAA) que são provavelmente responsíveis à luz (Terzaghi \& Cashmore, 1995; Gilmartin et al., 1990; Zhou, 1999) foram encontrados na região regulatória do gene da FtsH-p1 de tomate. Interessantemente, a luz tem sido relatada como um importante fator de regulação dos níveis de FtsH-p1 em plantas de alfafa (Ivashuta et al., 2002) e FtsH-p2 (var1) em Arabidopsis (Sakamoto et al., 2002), pois mostram seu envolvimento na degradação da proteína D1 presente nos fotossistemas II de plantas. Para verificar que a região promotora da $\mathrm{FtsH}$-p1 de tomate é realmente ativada por esse fator ambiental, foi montado um experimento onde as plântulas (3 meses) de todas as construções foram cultivadas em placas de Petri contendo meio MS em completa escuridão por 48 Horas. Após esse período, as placas foram transferidas para a luz $\left(250 \mu \mathrm{mol} / \mathrm{m}^{2} / \mathrm{s}\right)$ e a atividade GUS nas plântulas inteiras foi determinada seja via teste histoquímico (utilizando-se o substrato X-GLUC) seja pelo método fluorimétrico (com o substrato MUG) no tempo 12 e 24 horas após transferência para o ambiente luminoso (figura 23).

A expressão GUS pelo controle negativo pCambia $1281 Z$ foi insiginificante tanto medida pelo método fluorimétrico quanto pelo histoquímico. Pode-se observar ainda, que as plantas que expressam constitutivamente a enzima GUS, não mostram variação de atividade quando as condições são alteradas (escuro/luz). Entretanto, a atividade GUS proveniente das construções baseadas na região regulatória da FtsH-p1 indica que o gene da FtsH-p1 é regulado pela luz. A construção GUS1, que não contém a região TATA-BOX, apesar de apresentar alguma atividade, pode ser comparada ao ruído de fundo quando comparada com os outros cassetes de expressão. Aumentando-se o comprimento da região promotora, aumenta-se também a atividade da GUS em resposta à luz. Há que ressaltar que a presença de

a) 


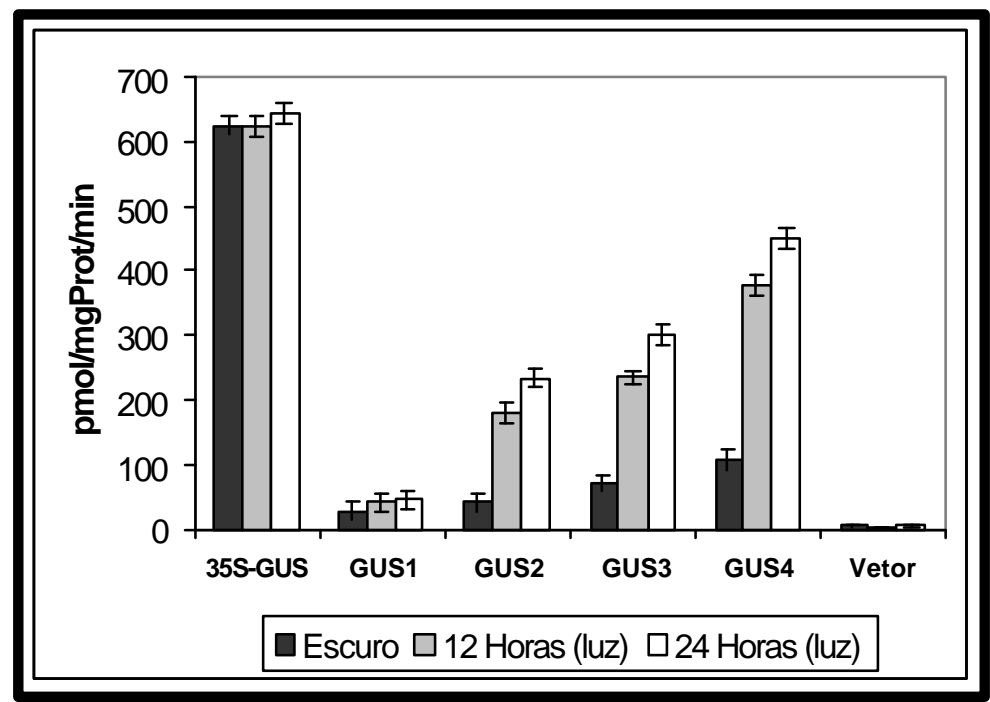

b)

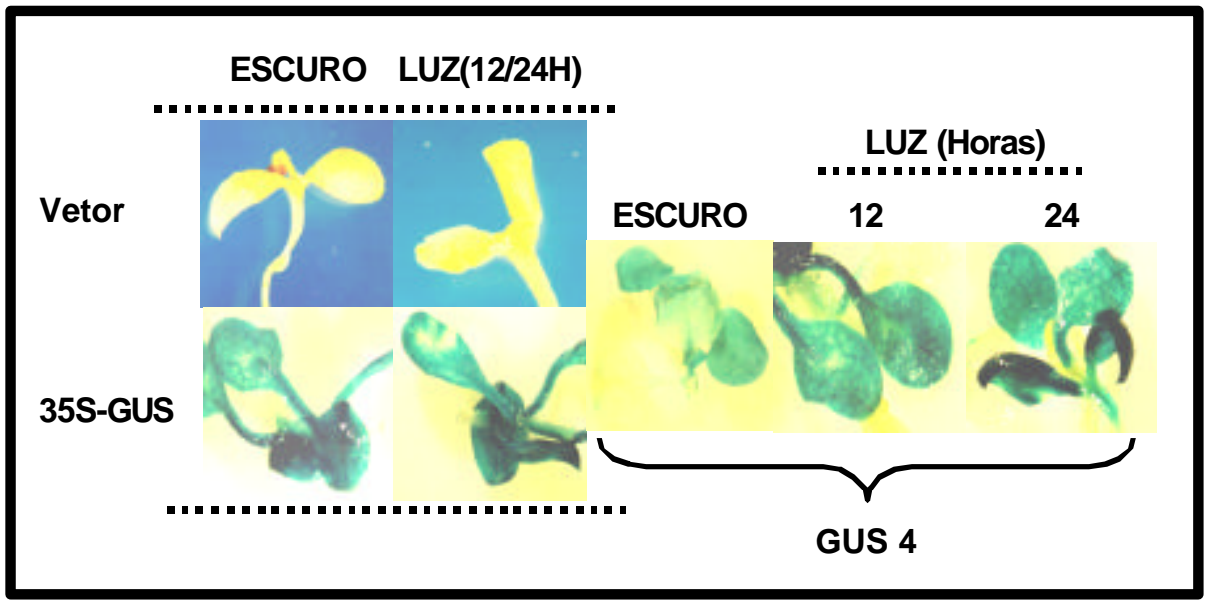

Figura 23 - a) Quantificação da atividade GUS em plântulas transgênicas de tabaco contendo as diferentes construções expostas a diferentes condições de luminosidade. As barras representam a média e o desvio padrão de 10 plantas. b) Detecção da atividade de GUS em plântulas transgênicas (GUS4) realizada pelo ensaio histoquímico.

motivos de 4 bases numa região promotora não necessariamente implica em sequências regulatórias. A probabilidade de ocorrência de uma dada sequência de 4 bases é de 1/64, portanto, provavelmente alguns dos vários motivos 
identificados podem ocorrer ao acaso. Além disso, as regiões promotoras normalmente apresentam uma frequência de AT relativamente superior àquelas encontradas nas sequência codantes e, sendo assim, alguns dos motivos identificados pelo programa de predição de sequências, podem não refletir a situação in vivo. Um outro aspecto, é que estes dados precisam ser reforçados com experimentos monitorando tanto a expressão do gene via mRNA (Northern Blot) e da proteína FtsH-p1. Na verdade, a proteína GUS é altamente resistente à ação de proteases (Jefferson et al., 1987). Portanto, mecanismos de regulação pós-traducionais que possam ocorrer na FtsH-p1, podem não refletir nos ensaios baseados na proteína GUS. Assim sendo, estes resultados preliminares necessitam ser interpretados com precaução e que experimentos adicionais fazem-se necessários para permitir uma melhor análise dos dados obtidos.

\subsection{Regulação por hormônios}

Como na região promotora clonada foram encontrados motivos que, segundo o programa PLACE database, são responsíveis ao hormônio auxina, giberelina e ácido abscísico, foi montado um experimento in vitro onde plântulas (de três meses) crescidas em meio MS normal, foram transferidas para placas contendo meio MS suplementadas com o hormônio em estudo (25 $\mu \mathrm{mol} / \mathrm{L})$ e a atividade GUS avaliada 3 dias depois.

Este experimento, semelhante ao anterior, foi realizado com o extrato protéico obtido das plântulas inteiras. A figura 24, mostra que os extratos das plantas tanto do controle negativo quanto do positivo não respondem a estes tratamentos hormonais. Por outro lado, uma resposta significativa aos hormônios auxina, citocinina e giberelina foi observada em todas as construções (GUS 2, GUS 3 e GUS 4). Entretanto, a construção GUS 2, não mostrou-se tão responsível aos hormônios auxina e citocinina como fizeram as construções GUS 3 e GUS4. Este resultado, confirma os dados disponibilizados pelo 
programa de predição. A região regulatória usada na construção GUS2, segundo este programa, não apresenta motivos que são conhecidamente responsíveis a estes hormônios. Diferentemente, as regiões regulatórias que foram usadas nas construções GUS 3 e GUS 4, apresentam o motivo em cis "TATTTGCTTAA" que segundo Nagao e colaboradores, (1993) é reconhecidamente um motivo responsível àeste hormônio de crescimento.

Entretanto, para estabelecer se a FtsH-p1 de tomate é um elemento da resposta primária ou secundária da auxina necessita-se realizar novos experimentos onde a expressão temporal deve ser acompanhada não apenas e um único ponto ( 3 dias após a transferência para o meio contendo o hormônio) mas sim, desde o momento em que foi estabelecida a transferência do meio de crescimento. Segundo Abel \& Theologis (1996), a cascata de sinalização que se inicia após a percepção do hormônio vegetal auxina gera, em questão de minutos, aumento ou diminuição da expressão gênica de muitos genes (genes de resposta primária=auxin/IAA) sem que haja a necessidade da síntese de novas proteínas. Posteriormente, a nova rota de regulação iniciada por esses genes, segundo dados mais recentes (Zenzer et al., 2001), coloca a regulação proteolítica como um paradigma emergente na via de sinalização da auxina. A remoção de reguladores por proteólise é um método bastante rápido e irreversível de eliminar suas atividades, e aparentemente, é o utilizado por esse hormônio vegetal. Sendo assim, podemos especular que a FtsH-p1 seria um dos componentes utilizados pela via de resposta à auxina no processo de degradação de seus potenciais substratos, no interior de cloroplastos.

Por outro lado, não encontramos (dados disponibilizados pelo programa de predição) nenhum motivo que seria responsível ao hormônio citocicina. O aumento observado da expressão da atividade GUS em resposta a este hormônio, poderia ser explicada devido ao conhecido efeito sinergístico que ocorre entre os hormônios auxina e citocinina (Coenen \& Lomax, 1998). Sabese, que após a exposição de tecidos foliares à soluções de citocininas, ocorre elevação de auxinas livres no interior de suas células. Assim, pode ser que o 
aumento na atividade GUS detectada nos tecidos das plantas transgências contendo as construções GUS 3 e GUS 4 na presença de citocinina seja explicada pelo aumento nos níveis endógenos da auxina.

a)

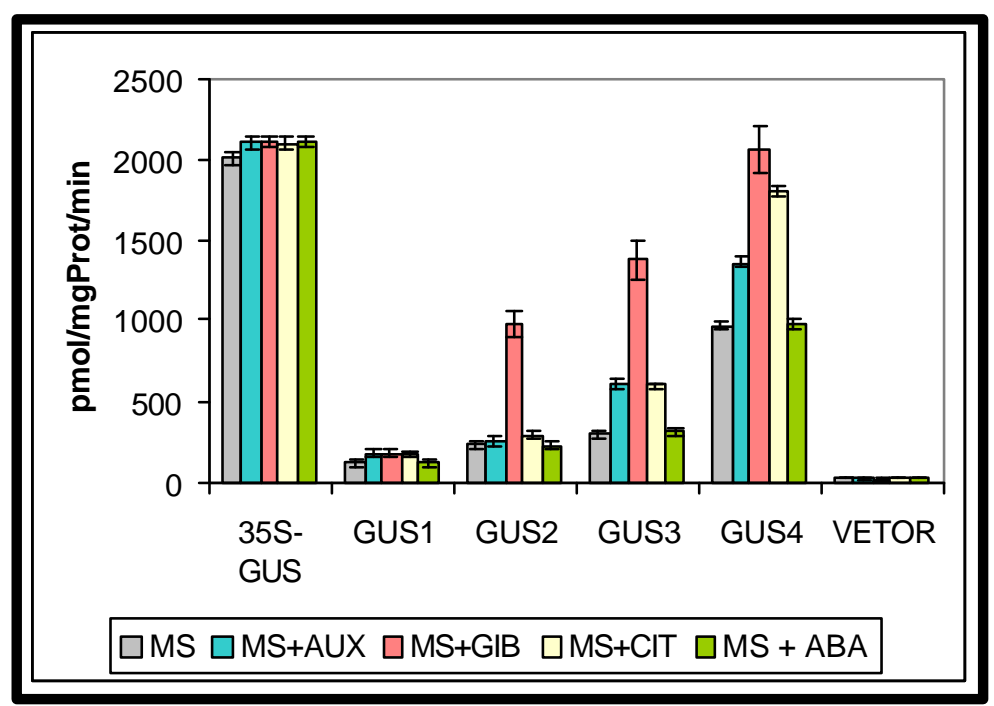

b)

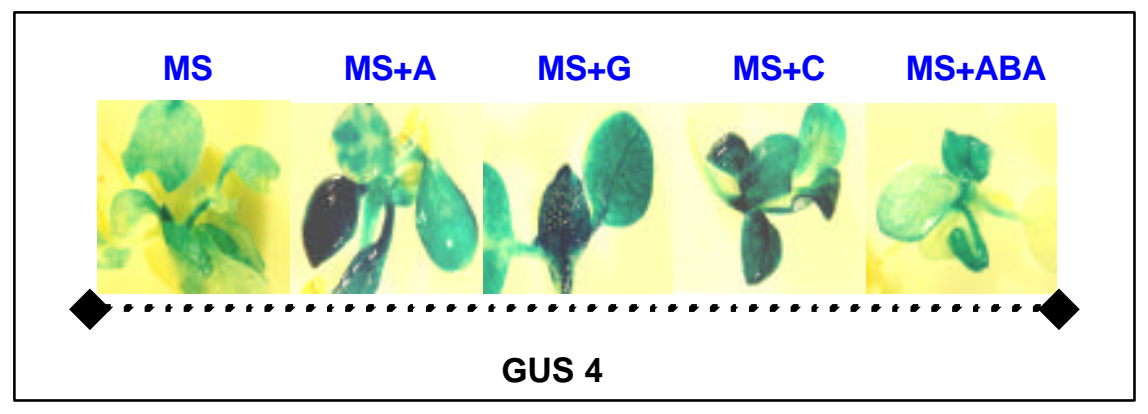

Figura 24 - a) Quantificação da atividade GUS em plântulas transgênicas de tabaco contendo as diferentes construções expostas a diferentes hormônios. As barras representam a média e o desvio padrão de 10 plantas. b) Detecção da atividade de GUS em plântulas transgênicas (GUS4) realizada pelo ensaio histoquímico. 
Contrariamente, na seqüência regulatória da $\mathrm{FtsH}-\mathrm{p} 1$ foram encontrados motivos que foram reportados como sendo regulados por ABA (CATGCA) (Ezcurra et al., 1999). Entretanto, os dados de expressão GUS indicam que a concentração do hormônio utilizada $(25 \mu \mathrm{mol} / \mathrm{L})$ não foi capaz de promover a expressão do gene. Ou ainda, apesar de apresentar um motivo aparentemente relacionado à expressão de genes induzidos por $A B A$, esta sequência cis per se não é suficiente para promover a expressão heteróloga do gene em questão. Uma outra possibilidade, é que uma sequência mais à montande da utilizada nos experimentos seja importante na ativação do gene. Porém, este resultado está em concordância com o obtido por Ivashuta e colaboradores (2002) que mostraram, utilizando a metodologia Northern Blot, que a FtsH-p1 de alfafa não apresenta regulação positiva nem negativa quando na presença deste hormônio. Conforme mencionado anteriormente, estes resultados precisam ser interpretados com cautela uma vez que experimentos adicionais tais como Northern e Western Blot são imprescindíveis para valorização dos dados aqui apresentados.

Como comentado anteriormente e visível na figura 24, diferente dos outros tratamentos, a resposta ao hormônio giberelina (GA3) deurse já com a construção GUS2. Analisando os dados provenientes da análise efetuada in silico, encontramos na sequência regulatória utilizada nessa construção a existência de um motivo (TTTTTCC=PYRIMIDINEBOX) que segundo Cercos e colaboradores (1999), trata-se de um elemento em cis envolvido nessa resposta. Os dados obtidos com os hormônios auxina e giberelina, condizem com o que relata a literatura. Novas interações entre os hormônios clássicos são descobertas a todo momento (Ross \& O’Neill, 2001). Auxina e giberelina, são requeridos para manter o crescimento e elongação de caules, e recentemente, Ross e colaboradores (2000) mostraram que a auxina esta envolvida na promoção da biossíntese da giberelina ativa cujos passos iniciais ocorrem no interior de plastídios. Essa recente descoberta mostrou um novo elo nas interações entre esses dois hormônios responsável por desencadear uma 
grande variedade de respostas envolvidas no desenvolvimento vegetal. Entretanto, dados adicionais seriam essenciais para tentar decodificar a rota estabelecida no processo de ativação da FtsH-p1 por esses hormônios. Se na região regulatória do gene FtsH-p1 de tomate se associam fatores transcricionais (fatores em trans) hormônios específicos, isto é, se são rotas completamente independentes, ou se existe interação sinergística entre esses fatores são dados que merecem ser estudados futuramente.

Certamente, as interações hormonais podem ser dramaticamente afetadas pelo tipo de órgão em questão (Ross \& O'Neill, 2001). Sendo assim, a fim de verificar a existência de uma interação entre regulação tecido-específica e resposta hormonal, foram analisados diferentes tecidos (folhas e caules) das plantas pertencentes à construção que apresentou maior resposta aos hormônios (GUS4) e os dados obtidos estão sintetizados na figura 25.

Percebe-se que os tecidos foliares e os tecidos caulinares responderam (aumento da expressão GUS) positivamente aos hormônios analisados, quando comparados aos tecidos que estavam em meio MS. A regulação positiva gerada pela presença destes hormônios, pode estar associada ao papel das FtsHs no interior dos cloroplastos e plastídios. Além de estar envolvida no processo de degradação da proteína D1 do fotossístema II após dano fotooxidativo, esta proteína poderia estar envolvida no processo de remanejamento de membranas no interior destas organelas (Sakamoto et al., 2002). A partir de estudos fisiológicos e bioquímicos, sabe-se que estes hormônios desencadeiam uma cascata de sinalizações que, na maior parte das vezes, ativam o processo de divisão, elongação e crescimento celular (Zenzer et al., 2001). Sendo assim, na presença destes hormônios, é importante que a cascata de sinalização ative genes que são responsáveis pelo crescimento e remanejamento de membranas porque novas organelas devem ser rapidamente produzidas. A interpretação mais aprofundada destes dados passa por um melhor entendimento da função das FtsHs nos cloroplastos, além da identificação de substratos destas proteases. Entretanto, caso os dados sejam 
confirmados por Northern e Western blot, novas perspectivas relacionadas ao papel das FtsHs e sua regulação são trazidos a tona baseados no controle sua expressão por hormônios.
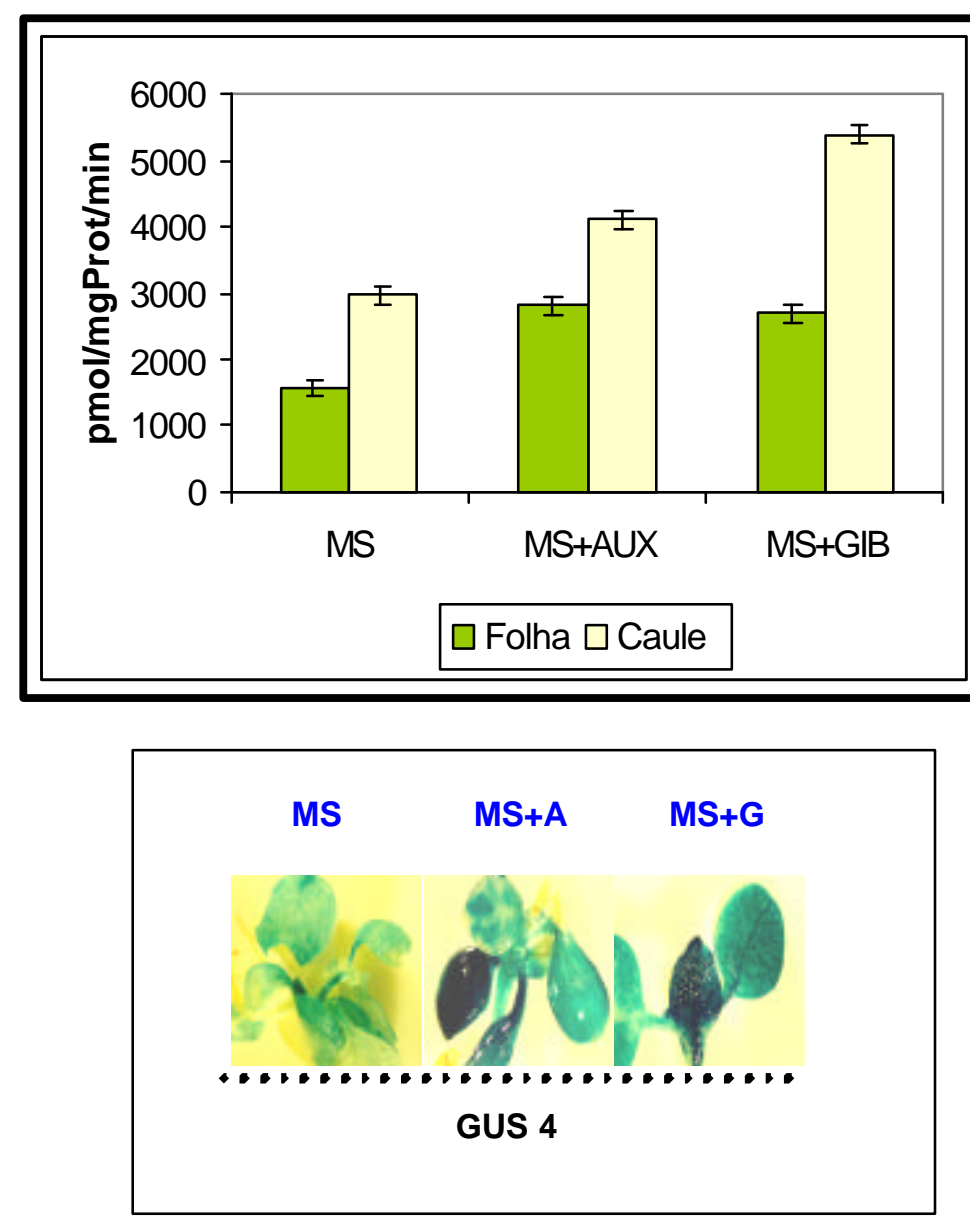

Figura 25 - a) Quantificação da atividade GUS tecido específica em plântulas transgênicas de tabaco (GUS4). As barras representam a média e o desvio padrão de 10 plantas. b) Detecção da atividade de GUS em plântulas transgênicas (GUS4) realizada pelo ensaio histoquímico.

\subsection{Efeito do $\mathrm{H}_{2} \mathrm{O}_{2}$ na expressão da FtsH-p1}


Com o objetivo de estudar o efeito do estresse oxidativo na regulação da expressão do gene GUS controlado pelo promotor da FtsH-p1 de tomate, plantas (3 meses) foram retiradas do meio MS e mergulhadas em uma solução de $\mathrm{H}_{2} \mathrm{O}_{2}(0,3 \%)$ por cerca de 30 minutos. Neste experimento, poderia se esperar um aumento na expressão do gene uidA controlado por nossa região regulatória, uma vez que dados da literatura indicavam que um substrato da $\mathrm{FtsH}$, a proteína D1 é alvo de intenso dano fotooxidativo. Segundo Moon e colaboradores, (2003), o $\mathrm{H}_{2} \mathrm{O}_{2}$ é uma das principais moléculas sinalizadoras que além de participar das respostas às injúrias e defesa àpatógenos, são capazes de gerar danos aos fotossistemas (geram estresse fotoxidativo). Assim, em presença da água oxigenada, esperáva-se que as células na tentativa de reparar os FSII, aumentassem a expressão GUS. Entretanto, as plantas expressando as construções GUS2, GUS3 e GUS4, responderam negativamente àpresença do $\mathrm{H}_{2} \mathrm{O}_{2} \mathrm{~A}$ figura 26 mostra os resultados obtidos apenas com a construção GUS4. Apesar de não estarem representados, tanto as plantas controles (contendo 0 vetor) quanto ì que expressam constitutivamente a proteína GUS não apresentaram alterações de atividade (dados não mostrados). 


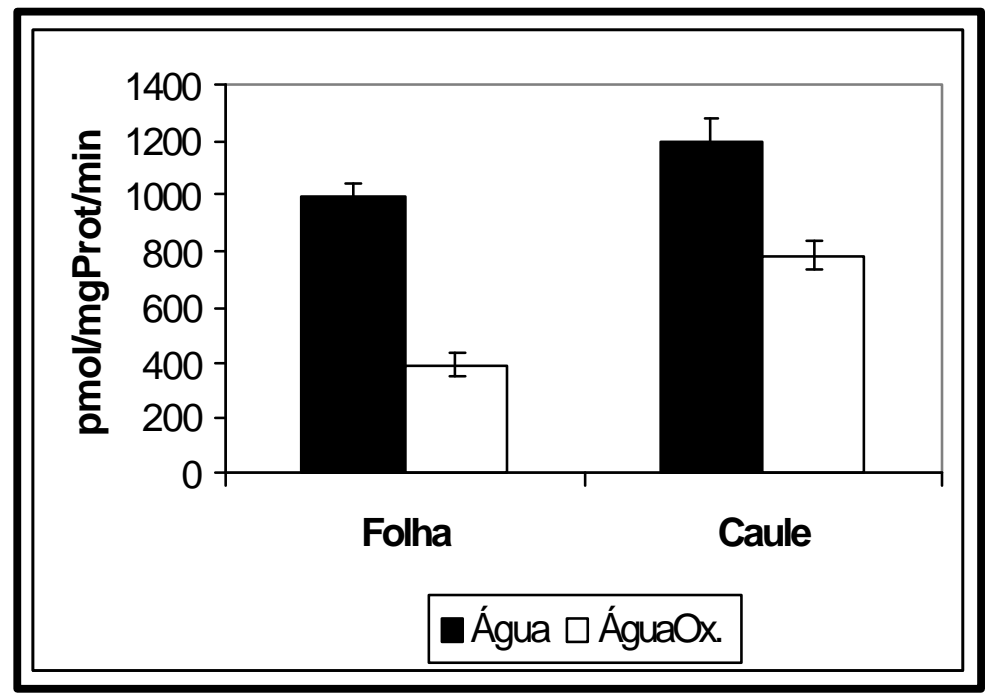

Figura 26 - Quantificação da atividade GUS em diferentes tecidos de plântulas transgênicas de tabaco contendo a construção GUS4 expostas a $\mathrm{H}_{2} \mathrm{O}_{2}$. As barras representam a média e o desvio padrão de 10 plantas.

Uma possível explicação reside no fato de que plantas de tabaco em presença do vírus do mosaico do tabaco, aceleram a resposta hipersensível diminuindo a expressão da FtsH-p1, para que os FSII não sejam reparados e a célula infectada sofra morte celular (não extravasamento do vírus) (Seo et al., 2000). Entretanto, Kovtun e colaboradores (2000) mostraram que a $\mathrm{H}_{2} \mathrm{O}_{2}$ é um potente ativador de uma MAP quinase (mitogen-activated protein kinase) em células foliares de Arabidopsis. A ANP1 (que é a MAPK ativada), após sua ativação pela água oxigeneda, inicia uma cascata de fosforilações que ativa genes envolvidos na resposta ao estresse oxidativo, porém, bloqueia a ação da auxina, paralisando o ciclo celular. Esta observação estabelece uma conexão com os resultados obtidos a partir do efeito da auxina na expressão dos cassetes. Portanto, em presença do agente abiótico $\left(\mathrm{H}_{2} \mathrm{O}_{2}\right)$, a região promotora 
da FtsH-p1 seria inibida de forma semelhante aos genes que são regulados por esse hormônio.

\subsection{Estresse salino e efeito temperatura}

Para verificar se outras formas de estresse químico e ambiental afetavam a regulação da expressão controlada pela região promotora em estudo, as plantas crescidas em meio MS (3 meses) foram transferidas para meio MS com alta concentração salina (250mmol/L de $\mathrm{NaCl})$. O NaCl também é um agente abiótico gerador de espécies reativas de oxigênio (ROS) e possivelmente poderia causar danos no FSII (Willekens et al., 1997). Entretanto, observa-se que as plantas não apresentaram alteração na expressão, medida pela atividade da enzima GUS (figura 27). No gráfico está representado apenas os valores obtidos com a construção GUS 4, pois representa o que ocorreu com as outras construções. Este dado está de acordo com resultados obtidos por Ivashuta et al., (2002) no qual os autores não encontraram alteração na expressão da FtsH-p1 de alfafa quando em presença de $\mathrm{NaCl}$, mostrando que semelhantemente ao ocorrido com o hormônio ABA, o acúmulo da FtsH-p1 não faz parte de um processo geral de respostas envolvidas na eliminação do estresse oxidativo. 
a)

b)
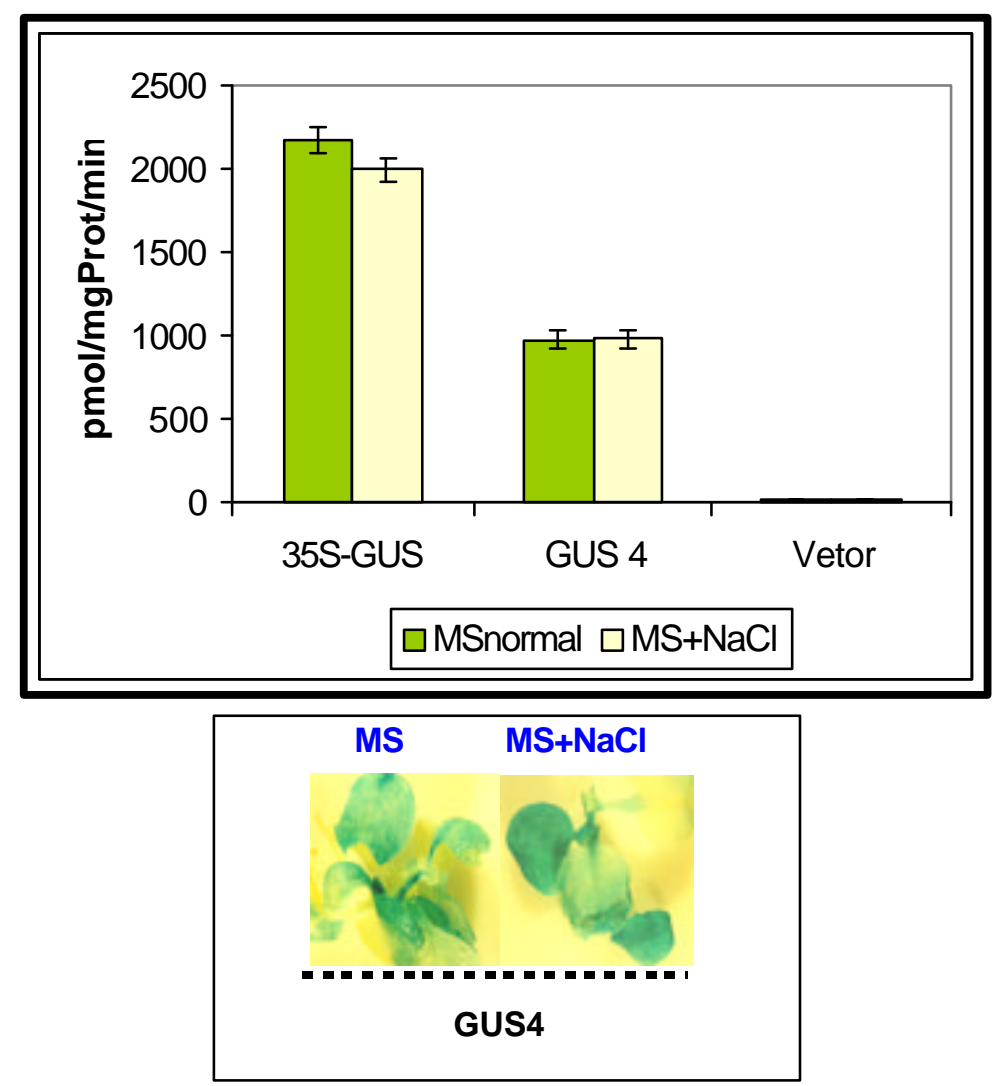

Figura 27 - a) Quantificação da atividade GUS em plântulas transgênicas de tabaco (GUS4) sob estresse salino. As barras representam a média e o desvio padrão de 10 plantas. b) Detecção da atividade de GUS em plântulas transgênicas (GUS4) realizada pelo ensaio histoquímico.

Uma observação interessante e que contraria em parte os dados de Ivashuta e colaboradores (2002) é que não foram observadas alterações na expressão GUS em diferentes temperaturas (figura 28). Segundo estes autores, quando as plantas de alfafa eram aclimatadas e colocadas em condições onde a 
temperatura alcançava $2^{\circ} \mathrm{C}$, as células respondiam aumentando a expressão da FtsH-p1. A situação era completamente invertida, quando elas eram expostas a altas temperaturas $\left(42^{\circ} \mathrm{C}\right.$ por 3 horas). Estes resultados contrastantes devem ser considerados com cautela devido æ̀s particularidades de cada experimento. Primeiro, as plantas utilizadas neste estudo não foram aclimatadas e a temperatura que utilizada neste trabalho de $58^{\circ} \mathrm{C}$ (3 dias) foi superior àquela utilizada pelos autores. Um outro aspecto não menos importante, é que neste estudo foram analisadas plantas de tabaco e no trabalho de Ivashuta et al., (2002), o modelo experimental foi em alfafa. É de se supor que possa haver uma regulação diferencial no controle da expressão das FtsH-p1 entre as plantas analisadas, resultando em respostas distintas para alguns tratamentos.

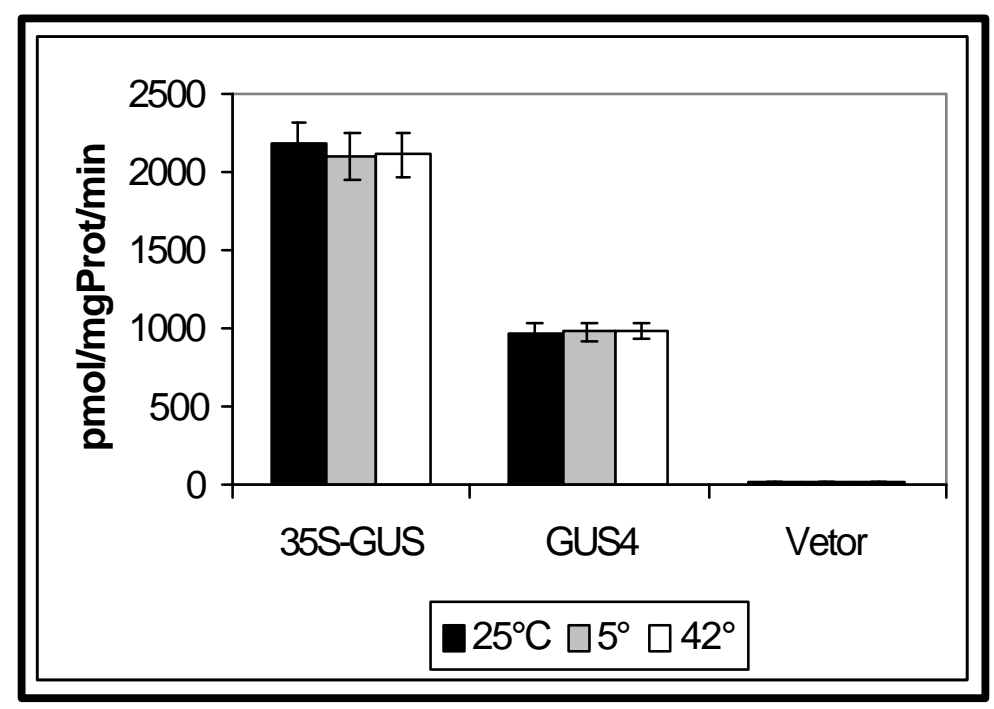

Figura 28 - Quantificação da atividade GUS em plântulas transgênicas de tabaco (GUS4) em diferentes regimes de temperatura. As barras representam a média e o desvio padrão de 10 plantas.

Como comentado anteriormente, é necessário analisar estes dados não de forma absoluta, mas que necessitam de estudos complementares para permitir uma interpretação mais sólida do trabalho. Neste sentido, técnicas 
complementares como Northern e Western blot fornecerão subsídios importantes quanto aos aspectos regulatórios da FtsH-p1, tanto a nível transcricional, pós-transcricional, traducional e pós-traducionais, etc). Outro aspecto que merece ser mencionado refere-se ao tamanho da região clonada. Apesar de 1700 nucleotídeos ser uma região regulatória significativa, dada a complexidade do genoma, não se pode excluir a possibilidade de que outras regiões regulatórias estejam ausentes e por isso interfiram nos efeitos analisados. Finalmente, não menos importante, há que se considerar que o trabalho em questão utiliza um sistema heterólogo de expressão, isto é, o promotor de tomate sendo expresso em plantas de tabaco. Apesar de serem da mesma família, pode ser que haja algum requerimento por um fator trancricional espécie específico que garantiria a expressão ou não sob determinadas condições, apesar de que diversos estudos na literatura venham sendo reportados baseados em sistemas de expressão análogos. 


\section{CONCLUSÕES}

Tendo em vista os resultados apresentados, conclui-se que:

> A FtsH-p1 de tomate contém todos os motivos conservados (ATPásicos e metaprotease) característicos de uma protease FtsH (família AAA) e está localizada no interior de plastídios,

A FtsH-p1 de tomate é exportada aos tilacóides por um mecanismo incomum e que difere dos processos conhecidos de direcionamento de proteínas à membranas,

> A FtsH-p1 de tomate não apresenta o clássico motivo RRXFLK envolvido no direcionamento de proteínas aos tilacóides pelo mecanismo Tat,

> A região promotora da $\mathrm{FtsH}-\mathrm{p} 1$ de tomate responde diferencialmente a estímulos como luz e hormônios vegetais. 


\section{REFERÊNCIAS BIBLIOGRÁFICAS}

ABEL, S.; THEOLOGIS, A. Early genes and auxin action. Plant Physiology, v.111, n.1, p.9-17, 1996.

ADAM, Z.; OSTERSETZER, O. Degradation of unassembled and damaged thylakoid proteins. Biochemical Society Transactions, v.29, n.4, p.427430, 2001.

ADAM, Z.; ADAMSKA, I.; NAKABAYASHI, K.; OSTERSETZER, O.; HAUSSUHL, K.; MANNUELL, A.; ZHENG, B.; VALLON, O.; RODERMEL, S.R.; SHINOZAKI, K.; CLARKE, A.K. Chloroplast and mitochondrial proteases in Arabidopsis: a proposed nomenclature. Plant Physiology, v.125, n.4, p.1912-1918, 2001.

AKIYAMA, Y.; YOSHIHISA, T.; ITO, K. FtsH, a membrane-bound ATPase, forms a complex in the cytoplasmic membrane of Echerichia coli. The Journal of Biological Chemistry, v.270, n.40, p.23485-23490, 1995.

AKIYAMA, Y.; ITO, K. Roles of holigomerization and membrane association in ATPase and proteolytic activities of FtsH in vitro. Biochemistry, v.40, n.25, p.7687-7693, 2001. 
ARLT, H.; TAUER, R.; FELDMANN, H.; NEUPERT, W.; LANGER, T. The YTA10-12 complex, an AAA protease with chaperon-like activity in the inner membrane of mitochondria. The Cell, v.85, n.6, p.875-885, 1996.

ARLT, H.; STEGLICH, G.; PERRYMAN, R.; GUIARD, B.; NEUPERT, M.; LANGER, T. The formation of respiratory chain complexes in mitochondria is under the proteolytic control of $m$-AAA protease. EMBO Journal, v.17, n.16, p.4837-4847, 1998.

ARVIS, P.; SOLL, J. Toc, Tic and chloroplast protein import. Biochymica Biophysica Acta, v.154, n.1-2, p.64-79, 2001.

BAILEY, S.; SILVA, P.; NIXON, P.J.; MULLINEAUX, C.; ROBINSON, C.; MANN, N. Auxiliary functions in photosynthesis: the role of the $\mathrm{FtsH}$ protease. Biochemical Society Transactions, v.29, n.4, p.455-459, 2001.

BAILEY, S.; THOMPSON, E.; NIXON, P.J.; HORTON, P.; MULLINEAUX, C.W.; ROBINSON, C.; MANN, N.H. A critical role for the Var2 FtsH homologue of Arabidopis thaliana in the photosystem II repair cycle in vivo. The Journal of Biological Chemistry, v.277, n.3, p.2006-2011, 2002.

BARATA, R.M.; CHAPARRO, A.; CHABREGAS, S.M.; GONZÁLES, R.; LABATE, C.A.; AZEVEDO, R.A.; SARATH, G.; LEA, P.J.; SILVA-FILHO, M.C. Targeting of the soybean leghemoglobin to tobacco chloroplasts: effects on aerobic metabolism in transgenic plants. Plant Science, v.155, n.2, p.193-202, 2000. 
BARTLETT, S.G.; GROSSMAN, A.R.; CHUA, N-H. Methods in chloroplast Molecular Biology. In: EDEIMAN, M.; HALICK, R.B.; CHUA, NH. (Ed.). In vitro synthesis and uptake of cytoplasmatic-synthesized chloroplast proteins. Amsterdam: Elsevier North-Holland Biomedical Press, 1982. p.1081-1091.

BEYER, A. Sequence analysis of the AAA protein family. Protein Science, v.6, n.10, p.2043-2058, 1997.

BOCHTLER, M.; HARTMANN, C.; SONG, H.K.; BOURENKOV, G.P.; BARTUNIK, H.D.; HUBER, R. The structures of HsIU and the ATPdependent protease HsIU-HsiV. Nature, v.404, n.6771, p.800-805, 2000.

BRADFORD, M.M. A rapid and sensitive method for the quantification of microgram quantities of protein utilizing the principle of protein-dye binding. Analytical Biochemistry, v.72, n.1-2, p.248-254, 1976.

BRASILEIRO, A.C.M; CARNEIRO, V.T.C. (Ed.). Manual de transformação de plantas. Brasília: Embrapa, SPI/Embrapa, Cenargem, 1998. 309p.

BRUCE, B. Chloroplast transit peptides: structure, function and evolution. Trends in Biochemistry Science, v.10, n.10, p.440-447, 2000.

BRUSER, T.; SANDERS, C. An alternative model of the twin arginine translocation system. Microbiology Research, v.158, n.1, p.7-17, 2003.

BUTLER, J.E.F.; KADONAGA, J.T. The RNA polymerase II core promoter: a key component in the regulation of gene expression. Genes and Development, v.16, n.20, p.2583-2592, 2002. 
CERCOS, M.; GOMEZ-CADENAS, A.; HO, T.H.D. Hormonal regulation of a cysteine proteinase gene, EPB-1, in barley aleurone layers: cis-and transacting elements involved in the co-ordinated gene expression regulated by gibberellins and abscisic acid. The Plant Journal, v.19, n.2, p.107-118, 1999.

CHABREGAS, S.M.; LUCHE, D.D.; FARIAS, L.P.; RIBEIRO, A.F.; VAN SLUYS, M-A.; MENCK, C.F.M.; SILVA-FILHO, M.C. Dual targeting properties of the $\mathrm{N}$-terminal sequence of Arabidopsis thaliana $\mathrm{THI} 1$ protein to mitochondria and chloroplasts. Plant Molecular Biology, v.46, n.6, p.639-650, 2001.

CHEN, K.; CHEN, X.; SCHNELL, D.J. Initial binding of preproteins involving the Toc159 receptor can be bypassed during import into chloroplast. Plant Physiology, v.122, n.3, p.813-822, 2000.

CHEN, M.; CHOI, Y.D.; VOYTAS, D.; RODERMEL, S. Mutations in the Arabidopsis VAR2 locus cause leaf variegation due to the loss of a chloroplastic FtsH protease. The Plant Journal, v.22, n.4, p.303-313, 2000.

COENEN, C.; LOMAX, T. The diageotropica gene differentially affects auxin and citokinin responses throughout development in tomato. Plant Physiology, v.117, n.1, p.63-67, 1998.

DALBEY, R.E.; ROBINSON, C. Protein translocation into and across the bacterial plasma membrane and the plant thylakoid membrane. Trends in Biochemistry Science, v.24, n.1, p.17-22, 1999. 
DUBY, G.; OUFATTOLE, M.; BOUTRY, M. Hydrophobic residues within the predicted N-terminal amphiphilic alpha-helix of a plant mitochondrial targeting presequence play a major role in in vivo import. The Plant Journal, v.27, n.6, p.539-549, 2001.

EDWARDS, A.; JOHNSTONE, C.; THOMPSON, C. A simple and rapid method for the preparation of plant genomic DNA for PCR analysis. Nucleic Acids Research, v.19, n.6, p.1349, 1991.

EICHACKER, L.A.; HENRY, R. Function of a chloroplast SRP in thylakoid protein export. Biochimica et Biophysica Acta, v.1541, n.1-2, p.120-134, 2001.

EHRMANN, M.A.; SCHEYHING, C.H.; VOGEL, R.F. In vitro stability and expression of green fluorescent protein under high pressure conditions. Letters in Applied Microbiology, v.32, n.4, p.230-234, 2001.

EMANUELSSON, O.; NIELSEN, H.; BRUNAK, S.; von HEIJINE, G. Predicting subcellular localization of proteins based on their $\mathrm{N}$-terminal amino acid sequence.Journal Molecular Biology, v.300, n.4, p.1005-1016, 2000.

ESTELLE, M. Proteases and cellular regulation in plants. Current Opinion in Plant Biology, v.4, n.3, p.254-260, 2001.

EZCURRA, I.; ELLERSTROM, M.; WYCLIFFE, P.; STALBERG, K.; RASK, L. Interaction between composite elements in the napA promoter: both the $B$ Box ABA-responsive complex and the RY/G complex are necessary for seedspecific expression. Plant Molecular Biology, v.40, n.4, p.699-709, 1999. 
FINAZZI, G.; CHASEN, C.; WOLLMAN, F.A.; deVITRI, C. Thylakoid targeting of Tat passenger proteins shows no $\Delta \mathrm{pH}$ dependence in vivo. EMBO Journal, v.22, n.4, p.807-815, 2003.

GIGLIONE, C.; SEVERO, A.; PIERRE, M.; BOISSON, B.; MEINNEL, T. The Identification of eukaryotic peptide deformylases reveals universality of $\mathrm{N}$ terminal protein processing mechanisms. EMBO Journal, v.19, n.21, p.59165929, 2000.

GILMARTIN, P.M.; SAROKIN, L.; MEMELINK, J.; CHUA, N-H. Molecular light switches for plant genes. The Plant Cell, v.2, n.5, p.369-378, 1990.

GLASER, E.; SJÖLING, S.; TANUDJI, M.; WHELAN, J. Mitochondrial protein import in plants. Signals, sorting, targeting, processing and regulation. Plant Molecular Biology, v.38, n.1-2, p.311-338, 1998.

HAUSSUHL, K.; ANDERSSON, B.; ADAMSKA, I. A chloroplast DegP2 protease performs the primary cleavage of the photodamaged D1 protein in plant photosystem II. EMBO Journal, v.20, n.4, p.713-722, 2001.

HEHL, R.; WINGENDER, E. Database-assisted promoter analyis. Trends in Plant Science, v.6, n.6, p.251-255, 2001.

HUGHENEY, P.; BOUVIER, F.; BADILLO, A.; D'HARLINGUE, A.; KUNTZ, M.; CAMARA, B. Identification of a plastid protein involved in vesicle fusion and/or membrane protein translocation. Proceedings of the National Academy of Sciences of the United States of America, v.92, n.12, p.5630-5634, 1995. 
IVASHUTA, S.; IMAI, R.; UCHIYAMA, K.; GAU, M.; SHIMAMOTO, Y. Changes in chloroplast FtsH-like gene during cold acclimation in alfafa (Medicago sativa). The Journal of Plant Physiology, v.159, n.1, p.85-90, 2002.

JEFFERSON, R.A.; KAVANAGH, T.A.; BEVAN, M.W. GUS fusions: $\beta$ glucuronidase as a sensitive and versatile gene fusion marker in higher plants. EMBO Journal, v.6, n.13, p.3901-3907, 1987.

KARATA, K.; INAGAWA, T.; WILKINSON, A.J.; TATSUTA, T.; OGURA,T. Dissecting the role of a conserved motif (the second region of homology) in the AAA family of ATPases. Journal of Biological Chemistry, v.271, n.37, p.26225-26232, 1999.

KEEGSTRA, K.; CLINE, K. Protein import and routing systems of chloroplasts. The Plant Cell, v.11, n.4, p.557-570, 1999.

KEENAN, R.J.; FREYMANN, D.M.; STROUD, R.M.; WALTER, P. The signal recognition particle. Annual Review Biochemistry, v.70, p.755-775, 2001.

KOHLER, R.H.; ZIPFEL, W.R.; WEBB, W.W.; HANSON, M.R. The green fluorescent protein as a marker to visualize plant mitochondria in vivo. The Plant Journal, v.11, n.3, p.613-621, 1997.

KOVTUN, Y.; CHIU, W.L.; TENA, G.; SHEEN, J. Functional analysis of oxidative stress-activated mitogen-activated protein kinase cascade in plants. Proceedings of the National Academy of Sciences of United States of America, v.97, n.6, p.2940-2945, 2000.

LAEMMLI, U.K. Cleavage of structural proteins during the assembly of the head of bacteriophage T4. Nature, v.227, n.259, p.680-685, 1970. 
LANGER, T. AAA proteases: cellular machines for degrading membrane proteins. Trends in Biochemistry Science, v.25, n.5, p.247-251, 2000.

LANGER, T.; KÄSER, M.; KLANNER, C.; LEONHARD, K. AAA proteases of mitochondria: quality control of membrane proteins and regulatory functions during mitochondrial biogenesis. Biochemical Society Transactions, v.29, n.4, p.431-436, 2001.

LEONHARD, K.; HERRMANN, J.M.; STUART, R.A.; MANNHAUPT, G.; NEUPERT, W.; LANGER, T. AAA proteases with catalytic sites on opposite membrane surfaces comprise a proteolytic system for the ATP-dependent degradation of inner membrane proteins in mitochondria. Embo Journal, v.15, n.16, p.4218-4229, 1996.

LI, X.; HENRY, R.; YUAN, J.; CLINE, K.; HOFFMAN, N.E. A chloroplast homologue of the signal recognition particle subunit SRP54 is involved in the post-translational integration of a protein into thylakoid membranes. Proceedings of the National Academy of Sciences of United States of America, v.92, n.9, p.3789-3793, 1995.

LINDAHL, M.; TABAK, S.; CSEKE, L.; PICHERSKY, E.; ANDERSON, B.; ADAM, Z. Identification, characterization and molecular cloning of homologue of the bacterial FtsH protease in chloroplasts in higher plants. Journal of Biological Chemistry, v.271, n.46, p.29329-29334, 1996.

LINDAHL, M.; SPETEA, C.; HUNDAL, T.; OPPENHEIM, A.B.; ADAM, Z.; ANDERSSON, B. The thylakoid FtsH protease plays a role in the light-induced turnover of the photosystem II D1 protein. The Plant Cell, v.12, n.3, p.419$431,2000$. 
LIU, Y.G.; WHITTIER, R.F. Thermal asymmetric interlaced PCR: automatable amplification and sequencing of insert end fragments from P1 and YAC clones for chromosome walking. Genomics, v.25, n.3, p.674-681, 1995.

LUPAS, A.N.; MARTIN, J. AAA proteins. Current Opinion in Structural Biology, v.12, n.6, p.746-753, 2002.

MADUEÑO, F.; BRADSHAW, S.A.; GRAY, J.C. The thylakoid-targeting domain of the chloroplast Rieske iron-sulfur protein is located in the N-terminal hydrophobic region of the mature protein. Journal of Biological Chemistry, v.269, n.26, p.17458-17463, 1994.

MARBACH, P.A.S.; COELHO, A.S.G.; SILVA-FILHO, M.C. Mitochondrial and chloroplast localization of FtsH-like proteins in sugarcane based on their phylogenetc profile. Genetics and Molecular Biology, v.24, n.1-4, p.183190, 2001.

MARQUES, J.P.; DUDECK, I.; KLÖSGEN, R.B. Targeting of EGFP chimeras within chloroplasts. Molecular Genetics and Genomics. /No prelo/

MATTOO, A.K.; MARDER, J.B.; EDELMAN, M. Dynamics of the photosystem II reaction center. The Cell, v.56, n.2, p.241-246, 1989.

MELIS, A. Photosystem II damage and repair cycle in chloroplasts: what modulates that the rate of photodamage in vivo ? Trends in Plant Physiology, v.4, n.4, p.130-134, 1999.

MLYNAROVA, L.; KEIZER, L.; STIEKEMA, W.J.; NAP, J.P. Approachlng the lower limits of transgene variability. The Plant Cell, v.8, n.9, p.1589-1599, 1996. 
MOLIK, S.; KARNAUCHOV, I.; WEIDLICH, C.; HERRMANN, R.G.; KLÖSGEN, R.B. The Rieske Fe/S protein of the cytochrome b6/f complex in chloroplasts: missing link in the evolution of protein transport pathways in chloroplasts ? Journal of Biological Chemistry, v.276, n.46, p.42761-42766, 2001.

MOON, H.; LEE, B.; CHOI, G.; SHIN, D.; PRASAD, D.T.; LEE, O.; KWAK, S.S.; KIM, D.H.; NAM, J.; BAHK, J.; HONG, J.C.; LEE, S.Y.; CHO, M.J.; LIM, C.O.; YUN, D.J. NDP kinase 2 interacts with two oxidative stress-activated MAPKs to regulate cellular redox state and enhances multiple stress tolerance in transgenic plants. Proceedings of the National Academy of Sciences of the United States of America, v.100, n.1, p.358-363, 2003.

MORI, H.; SUMMER, E.L.; XIANYUE, M.; CLINE, K. Component specificity for the thylakoidal Sec and Delta $\mathrm{pH}$-dependent protein transport pathways. The Journal of Cell Biology, v.146, n.1, p.45-55, 1999.

MORI, H.; CLINE, K. Post-translational protein translocation into thylakoids by the Sec and $\Delta$ pH-dependent pathways. Biochimica et Biophysica Acta, v.1541, n.1-2, p.80-90, 2001.

MORI, H.; CLINE, K. A twin arginine signal peptide and the $\mathrm{pH}$ gradient trigger reversible assembly of the thylakoid $\Delta \mathrm{pH} / \mathrm{Tat}$ translocase. Journal of Cell Biology, v.157, n.2, p.205-210, 2002.

MURASHIGE, T.; SKOOG, F. A revised medium for rapid growth and biossays with tobacco tissue cultures. Plant Physiology, v.15, n.2, p.473-497, 1962.

NAGAO, R.T.; GOEKJIAN, V.H.; HONG, J.C.; KEY, J.L. Identification of proteinbinding DNA sequences in an auxin-regulated gene soybean. Plant Molecular Biology, v.21, n.6, p.1147-1162, 1993. 
NIELSEN, H.; ENGELBRECHT, J.; BRUNAK, S.; VONHEIJINE, G. Identification of prokariotic and eukariotic signal peptides and prediction of their cleavage sites. Protein Enginnering, v.10, n.1, p.1-6, 1997.

OSTERSETZER, O.; ADAM, Z. Light-stimulated degradation of an unassembled Rieske FeS protein by a thylakoid-bound protease: the possible role of the FtsH Protease. The Plant Cell, v.9, n.6, p.957-965, 1997.

PEETERS, N.M.; CHAPRON, A.; GIRITCH, A.; GRANDJEAN, O.; LANCELIN, D.; LHOMME, T.; VIVREL, A.; SMALL, I. Duplication and quadriplication of Arabidopisis thaliana cysteinyl-and asparaginyl-t-RNA syntase genes of organelar origin. Journal of Molecular Evolution, v.50, n.5, p.413-423, 2000.

PILON, M.; KRUIJFF, B.; WEISBEEK, P. New insights into the import mechanism of ferredoxin precursor into chloroplast. Journal of Biological Chemistry, v.267, n.4, p.2548-2556, 1992.

PFISTERER, J.; LACHMANN, P.; KLOPPSTECH, K. Transport of proteins into chloroplasts. Binding of nuclear-coded chloroplast proteins to the chloroplast envelope. European Journal of Biochemistry, v.126, n.1, p.143-148, 1982.

RICHTER, S.; LAMPPA, G.K. Stromal processing peptidases binds transit peptides and initiates their ATP-dependent turnover in chloroplast. The Journal of Cell Biology, v.147, n.1, p.33-43, 1999.

ROBERTS, C.S.; RAJAGOPAL, S.; SMITH, L.A.; NGUYEN, T.A.; YANG, W.; NUGROHO, S.; RAVI, K.S.; CAO, M.L.; VISAYACHANDRA, K.; PATELLI, V.; HARCOURT, R.L.; DRANSFIELD, L.; DESAMERO, N.; SLAMET, I.; KEESE, 
P.; KILIAN, A.; JEFFERSON, R.A. A comprehensive set of modular vectors for advanced manipulations and efficient transformation of plants by both Agrobacterium and direct DNA uptake methods. PCAMBIA Vector release manual versions 3.05. New York, 1997. 6p.

ROBINSON, C.; HYNDS, P.J.; ROBINSON, D.; MANT, A. Multiple pathways for the targeting of thylakoid proteins in chloroplasts. Plant Molecular Biology, v.38, n.1-2, p.209-221, 1998.

ROBINSON, C.; WOOLHEAD, C.; EDWARDS, W. Transport of proteins into and across the thylakoid. Journal of Experimental Botany, v.51, n.1, p.369-374, 2000.

ROOK, F.; BEVAN, M.W. Genetic approachs to understanding sugar response pathways. Journal of Experimantal Botany, v.54, n.382, p.495-501, 2003.

ROSS, J.; O'NEILL, D. New interactions between classical plant hormones. Trends in Plant Science, v.6, n.1, p.2-4, 2001.

RYAN, C.A. Protease inhibitors in plants: genes for improving defenses against insect and pathogens. Annual Review of Phytopathology, v.28, p.425-449, 1990.

SAKAMOTO, W.; SPIELEWOY, N.; BONNARD, G.; MURATA, M.; WINTZ, H. Mitochondrial localization of AtOXA1, an Arabidopisis homologue of yeast Oxa1p involved in the insertion and assembly of protein complexes in 
mitochondrial inner membrane. Plant Cell Physiology, v.41, n.10, p.11571163, 2000.

SAKAMOTO, W.; TAKAYUKI, T.; HANBA-TOMITA, Y.; SODMERGEN; MURATA, M. The VAR1 locus of Arabidopsis encodes a chloroplastic FtsH and is responsible for leaf variegation in the mutant alleles. Genes to Cells, v.7, n.8, p.769-780, 2002.

SAMBROOK, J.; FRITSCH, E.F.; MANIATIS, T. Molecular clonning: a laboratory manual. New York: Cold Spring Harbor Laboratory, 2001. 3v.

SHATZ, G.; DOBBERSTEIN, B. Common principles of protein translocation across membranes. Science, v.271, n.5255, p.1519-1526, 1996.

SCHLEIFF, E.; KLÖSGEN, R.B. Without a little help from "my" friends: direct insertion of proteins into chloroplast membranes ? Biochimica et Biophysica Acta, v.1541, n.(1-2), p.22-33, 2001.

SCHULER, M.A.; ZIELINSKI, R.E. Methods in plant molecular biology. New York: Academic Press, 1989. 171p.

SCHUMANN, W. FtsH- a single-chain charonin ?. FEMS Microbiology Reviews, v.23, n.1, p.1-11, 1999.

SEO, S.; OKAMOTO, M.; IWAI, T.; IWANO, M.; FUKUI, K.; ISOGAI, A.; NAKAJIMA, N.; OHASHI, Y. Reduced levels of chloroplast FtsH protein in 
tobacco mosaic virus-infected tobacco leaves accelerate the hypersensitive reaction. The Plant Cell, v.12, n.6, p.917-932, 2000.

SETTLES, A.M.; MARTIENSSEN, R. Old and new pathways of export in chloroplasts and bacteria. Trends in Cell Biology, v.8, n.12, p.494-501, 1998.

SILVA-FILHO, M.C.; WIEËRS, M.C.; FLÜGGE, U.I.; CHAUMONT, F.; BOUTRY, $M$. Different in vitro and in vivo targeting properties of the transit peptide of a chloroplast envelope inner membrane protein. The Journal of Biological Chemistry, v.272, n.24, p.15264-15269, 1997.

SILVA-FILHO, M.C. One ticket for multiple destinations: dual targeting of proteins to distinct subcellular localizations. Current Opinion in Plant Biology. /No prelo/

SINGH, K.B. Transcriptional regulation in plants: the importance of combinatorial control. The Plant Physiology, v.118, n.4, p.1111-1120, 1998.

SOLL, J. Protein import to chloroplasts. Current Opinion in Plant Biology, v.5, n.6, p.529-535, 2002.

SOUSA, M.C.; TRAME, C.B.; TSURUTA, H.; WILBANKS, S.M.; RESSY, V.S.; McKAY, D.B. Crystal and solution structures of an HslUV proteasechaperone complex. The Cell, v.103, n.4, p.633-643, 2000.

SUMMER, E.J.; CLINE, K. Red bell pepper chromoplasts exhibit in vitro import competency and membrane of passenger proteins from the thylakoidal Sec 
and $\Delta \mathrm{pH}$ pathways but not the chloroplast Signal Recognition Particle pathway. Plant Physiology, v.119, n.2, p.575-584, 1999.

SUMMER, E.; MORI, H.; DETTLES, A.M.; CLINE, K. The thylakoid $\Delta \mathrm{pH}-$ dependent pathway machinery facilitates $\mathrm{RR}$-independent $\mathrm{N}$-tail protein integration. The Journal of Biological Chemistry, v.275, n.31, p.2348323483, 2000.

TAKECHI, K.; SODMERGEN; MURATA, M.; MOTOYOSHI, F.; SAKAMOTO, W. The YELLOW VARIEGATED (VAR2) locus encodes a homologue of $\mathrm{FtsH}$, an ATP-dependent protease in Arabidopsis. Plant Cell Physiology, v.41, n.12, p.1334-1346, 2000.

TERZAGHI, W.B.; CASHMORE, A.R. Photomorphogenesis: seeing the light in plant development. Current Biology, v.5, n.5, p.466-468, 1995.

TOMOYASU, T.; YAMANAKA, K.; SUZAKI, T.; BOULOC, P.; KATO, A.; NIKI, H; HIRAGA, S.; OGURA, T. Topology and subcellular localization of $\mathrm{FtsH}$ protein in Escherichia coli. Journal of Bacteriology, v.175, n.5, p.1352$1357,1993$.

TOWBIN, H.; STAEHELIN, T.; GORDON, J. Eletrophoretic transfer of proteins from polyacrylamide gels to nitrocellulose sheets: procedure and some applications. Proceedings of the National Academy of Sciences of the United States of America, v.76, n.9, p.4350-4354, 1974.

THORSNESS, P.E.; WHITE, K.H.; FOX, T.D. Inactivation of YME1, member of the FtsH-sEC18-PAS1-CDC48 family of putative ATPase-encoding genes, 
causes increases escape of DNA from mitochondria in Saccharomyces cerevisiae. Molecular Cell Biology, v.13, n.9, p.5418-5426, 1993.

VALENT, Q.A.; SCOTTI, P.A.; HIGH, S.; DEGIER, J.W.L.; VONHEIJINE, G.; LENTZEN, G.; WINTERMAYER, W.; OUDEGA, B.; LUIRINK, J. The Escherichia coli SRP and Sec B targeting pathways converge at the translocon. EMBO Journal, v.17, n.9, p.2504-2512, 1998.

VONHEIJINE, G.; STEPPUHN, J.; HERRMANN, R.G. Domain structure of mitochondrial and chloroplast targeting peptides. European Journal of Biochemistry, v.180, n.3, p.535-545, 1989.

WEST, A.G.; GASZNER, M.; FELSENFELD, G. Insulators: many functions, many mechanisms. Genes and Development, v.16, n.3, p.271-288, 2002.

WILLEKENS, H.; CHAMNONGPOL, S.; DAVEY, M.; SCHRAUDENER, M.; LANGEBARTELS, C.; VAN MONTAGU, M.; INZÉ, D.; VAN CAMP, W. Catalase is a sink for $\mathrm{H}_{2} \mathrm{O}_{2}$ and is indispensable, for stress defence in $\mathrm{C}_{B}$ plants. EMBO Journal, v.16, n.16, p.4806-4816, 1997.

WOOLHEAD, C.; BOLHUIS, A.; ROBINSON, C. Novel mechanisms for the targeting of protein into and across chloroplast membranes. Biochemical Society Transactions, v.28, n.4, p.491-494, 2000.

ZENSER, N.; ELLSMORE, A.; LEASURE, C.; CALLIS, J. Auxin modulates the degradation rate of Aux/IAA proteins. Proceedings of the National Academy of Sciences of the United States of America, v.98, n.20, p.11795-11800, 2001.

ZHOU, D.X. Regulatory mechanism of plant gene transcription by GT-elements and GT-factors. Trends in Plant Science, v.4, n.6, p.210-214, 1999. 